\title{
Articles
}

\section{The Uneasy Case for Wealth Transfer Taxation}

\author{
Edward J. McCaffery ${ }^{\dagger}$
}

\author{
CONTENTS
}

I. INTRODUCTION $\ldots \ldots \ldots \ldots \ldots \ldots \ldots \ldots \ldots \ldots \ldots \ldots \ldots \ldots \ldots \ldots \ldots . .284$

II. The liberal Egalttarian Case for (ANd Against) Wealth Transfer TAXATION . . . . . . . . . . . . . . . . . . . . . . . $\mathbf{2 8 9}$

III. The Estate Tax: Law, Effects, and Consequences . . . . . . . . . 297

A. The Law . . . . . . . . . . . . . . . . . . . . . . . . . 297

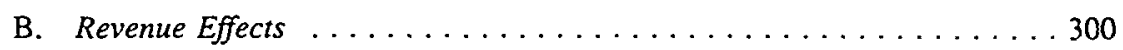

C. Capital Stock Effects . . . . . . . . . . . . . . . . 304

IV. The (Liberal) Failures of the Estate Tax $\ldots \ldots \ldots \ldots \ldots \ldots \ldots \ldots \ldots \ldots$

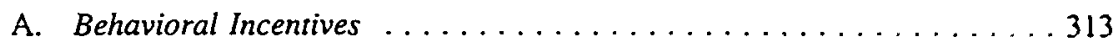

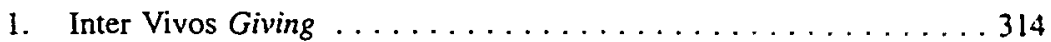

2. Consumption-Savings and Work-Leisure Decisions . . . . . 318

B. Distributive Effects ................... 322

$\doteqdot$ Professor of Law, University of Southern California Law Center. I would lihe to thank Brute Ackerman, Ellen Aprill. Michael Asimow, Boris Bitker. Bill Blatl. Marshall Cohen. Jules Coleman, Dick Craswell, Michael Graetz. Tom Griffith, Henry Hansmann. Bill Klcın. Alıchael Knoll. John Langbein. Morry Lipson, Roberta Romano. Reed Shuldiner, Jeff Stmad, and Michael Wachier for their scholarly input, and aiso all of the participants at the Southern California Tax Policy Discussion Group. the Harvard Law School Seminar on Tax Policy, and the Legal Theory Workshop at the University of Pennsylvania Law School for comments on earlier versions of this Arucle Mluch of this Article was written while I was a Visiting Professor at the Yale Law School, and I would like to thank my many tine students there, especially Carey Smith for his outstandıng research assistance 


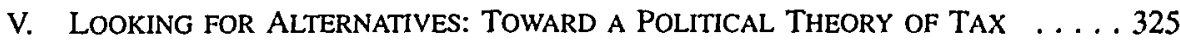

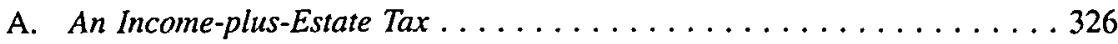

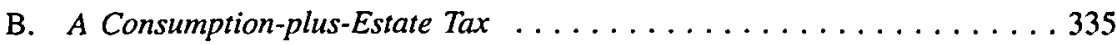

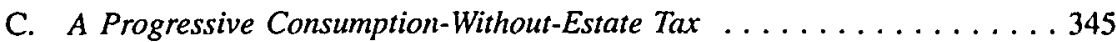

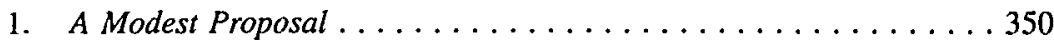

2. Rational Saving Under a Progressive Consumption Tax . . . . 353

3. Charitable Contributions $\ldots \ldots \ldots \ldots \ldots \ldots \ldots \ldots \ldots \ldots \ldots$

VI. The CASE Against DoIng Nothing $\ldots \ldots \ldots \ldots \ldots \ldots \ldots \ldots \ldots$

A. What's Wrong with a Voluntary Tax? $\ldots \ldots \ldots \ldots \ldots \ldots \ldots \ldots$

B. Living with Uncertainty .................. 361

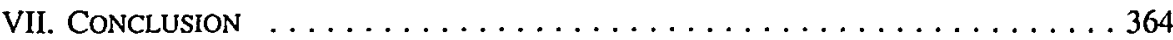

\section{INTRODUCTION}

Privately held wealth and its unequal distribution, and perhaps especially the transmission of such wealth across generations, have long been thought to pose particularly pernicious influences in a liberal democratic state. Thus, some form of a wealth transfer tax-most commonly an estate or an inheritance tax-has typically been a part of real-world and theoretically supported comprehensive tax systems. As our ideas about the role of other taxes have shifted, both in practice and in theory, our intellectual allegiance to a system of wealth transfer taxation in the United States has remained more or less fixed. The present estate tax is similar, in its essential form, to the initial estate tax implemented in 1916, ${ }^{\prime}$ and scholarly support for some type of wealth transfer tax, although far from universal, remains strong. ${ }^{2}$ Recently, some

1. Revenue Act of 1916, Pub. L. No. 64-271, §§ 201, 203, 38 Stat. 756, 777-78. The gift tax was first in place for two years in 1924-1925 and then enacted permanently in 1932. JOSEPH A. PECHMAN, FEDERAL TAX POLICY 236 (5th ed. 1987). For historical background, see generally John E. Donaldson, The Future of Transfer Taxation: Repeal, Restructuring and Refinement, or Replacement, 50 WASH. \& LEE L. REV. 539 (1993) (advocating abandonment of present estate and gift tax system and proposing two alternative models focusing on transferec); David M. Hudson, Tax Policy and the Federal Taxation of the Transfer of Wealth, 19 WILLAMETTE L. REV. 1, 9-32 (1983) (discussing history of federal wealth transfer taxation); Edward A. Zelinsky, The Estate and Gift Tax Changes of 1981: A Brief Essay on Historical Perspective, 60 N.C. L. REv. 821 (1982) (reviewing, in historical context, changes made by Ninety-Seventh Congress to estate and gift tax regime).

2. For representative tax policy theory on the estate tax, see DEATH, TAXES AND FAMILY PROPERTY: ESSAYS AND AMERICAN ASSEMBLY REPORT (Edward C. Halbach, Jr. ed., 1977) [hereinafter DEATH. TAXES AND Family PROPERTY]; W.D. Andrews, What's Fair About Death Taxes?, 26 NAT'L TAX J. 465 (1973); Mark L. Ascher, Curtailing Inherited Wealth, 89 MiCH. L. REv. 69 (1990); Gerard M. Brannon, Death Taxes in a Structure of Progressive Taxes, 26 NAT'L TAX. J. 451 (1973); David G. Duff, Taxing Inherited Wealth: A Philosophical Argument, 6 CAN. J.L. \& JURISPRUDENCE 3 (1993); Louis Eisenstcin, The Rise and Decline of the Estate Tax, 11 TAX L. REv. 223 (1956); Michael J. Graetz, To Praise the Estate Tax, Not To Bury It, 93 YALE L.J. 259 (1983); Harry L. Gutman, Reforming Federal Weallh Transfer Taxes After ERTA, 69 VA. L. REV. 1183 (1983); David Westfall, Revitalizing the Federal Estate and Gift Taxes, 83 HARV. L. REV. 986 (1970). For a careful discussion of reform proposals designed to 
scholars have even called for a confiscatory estate tax, or an abolition of inheritance altogether. ${ }^{3}$

But times have changed since 1916. Our political-philosophical ideas have evolved. The federal income tax has grown from a relatively small surcharge on the highest incomes into a massive, broad-based tax system. Corresponding to this expansion in breadth, we have shifted, both in theory and in practice, from an income toward a consumption tax model. ${ }^{5}$ Over threequarters of a century of experience with both estate taxes and nominal income taxation has strengthened our understanding of the possibilities and limitations of tax systems, all during a period of continued inequality of wealth, income, and consumption.

make the present gift and estate tax regime more effectuc. complete with numerous citations to the wider literature, see Joseph M. Dodge. Redong the Estate and Gift Tates Along Eass-To. Lalue Lanes. 43 Tax L. REV. 241 (1988). For a carefully worked-through accesstons tax model. see Eduard C Halbach. Jr, An Accessions Tax. 23 REAL PROP. PROB. \& TR. J 211 (1988) For an interesung hestorieal perspecuse on estate tax theory, see Zelinsky. supra note 1 For a careful stud.. largely critical of estate tacation, see George COOPER. A VOLLNTARY TAX? NEM PERSPECTIIES ON SOMIISTIC atED ESTATE TAY AVOIDANCE (1979). For recent criticisms of the gift and estate las. see Juel C Dobris. A Brief for the Abolition of All Transfer Taxes. 35 SYRACI SE L. REI 1215 (1984). Donaldson, supra note 1, Charles O. Galvin, To Bury the Estate Tax, Not To Pratse h. 52 TAx Norts 1+13 (199), For a general discussion and criticism of the lack of solid empirical grounding for theones on wealth transfer taxation.

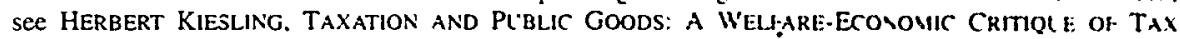
POLICY ANALYSIS 197 (1992) (suggesting that any book on distorive effeets of gift and estale taxes "would require a considerable body of empirical work. most of which has also not been done and is

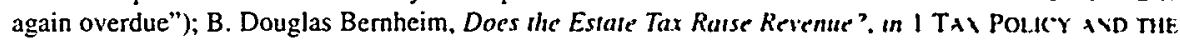
ECONOMY 113, 121-32 (Lawrence H. Summers ed.. 1987). Alan S Blinder. A Model of lnhertied Wealth. 87 Q.J. ECON. 608, 608 (1973) [hereinafter Blınder. Inherused Healhh] ("Josiah Stamp's lament that 'scientific economic inquiry into the subject of inheritance has thus been ven seanly' is as true in 1973 as it was in 1926."): Thomas A. Robinson. The Federal Health Transfer Taxes-A Requiem? I AM. J. TAX POL'Y 25, 38, 43 (1982).

3. See Ascher, supra note 2, at 73: D.W. Haslett. Is Inherifance Justified'. IS Pill. \& PI a AFFaIRS 122 (1986). There have also been recent political proposals to ughten the gift and estate tax Ser. $\&$ g . Barbara Kirchheimer, The Estate Tax: All-American or Un-American. 57 TAx Notus 1232, 1232 (1992), Marianne Taylor, Some Fear Congress W'll Make Death More Taung. CII Trib. Dec 7. 1992, at C!

4. See generally JOHN F. WITTE. THE POLITICS AND DEVElopMENT OF MIE FEDERAL IVCOME TAX $110-30$ (1985) (chronicling nse of income tax from clite to mass ta 3 )

5. I detail some of this movement. and make citations to the exiensuse literature on the income. versus-consumption debate, in Edward J. McCaffer. Tax Policv Unter a Hubrid Inconte. Consumption Tax, 70 TEX. L. REV. 1145 (1992) [hereinafter McCaffery. Hibrid) I discuss the consumption tax in much greater detail, infra parts V.B and V.C. For now, the reader unfamiliar w th the literature can best consider the consumption tax model in terms of the oft-cited Haig-Simons definition of inconie Income = Consumption + Savings. This celebrated definition is litle more than an accounting identuty. It tells us that sources equal uses, or, equivalently. that all income is etther spent (consumed) or not (saved) The definition also highlights the ease with which a broad-based lax can become a consumption model Simply subtracting Savings from both sides of the above identily yuelds- Constumption = Income Savings. We can, and in fact largely do. have a consumpuon tax model when we subtract savings from income; think, for example, of the treatment of IRAs or qualified pension plans. See MieCaffery. H,brid, supra, at 1150-55 (discussing consumption ideal and present hybnd). and cilalions thetein

6. See Edward N. Wolff. Changing Inequalin of Wealth. 82 AY Eco REV 552 (1992) Wolff's data suggest that there has been a slight decline in wealth inequality over the 20th century, but that this decline is almost entirely traceable to discrete penods of poor macroeconomic performance, such as the Great Depression and the stock marhet declines of the 1970's Wolff's dala also suggest that large inter vivos gifts contribute stgnificantly to wealth inequality. Id. at 557: infra part IV A 1. sec also STEPHEN R. MUNZER, A THEORY OF PROPERTY 380-95 (1990) (discussing role of gratuitous transfers in producing unequal wealth); Henry J. Aaron \& Alicia H. Munnell. Reassessing the Role for Weulh Transfer Taxes, 
Meanwhile, the estate tax does not, in fact, appear to be working. It does not raise significant revenue. It is and has always been riddled with large exceptions, exemptions, and exclusions. Most striking is the fact that the tax has never been and is not now popular. At the same time, a more sophisticated tax scholarship has given us a wider range of policy options than our untutored imaginations put forth eight decades ago. These changes, in theory and in practice, make the case for the estate tax ${ }^{7}$ more uneasy than initial intuitions might otherwise suggest.

What is most surprising in my analysis is that unease over the estate tax arises specifically on liberal grounds. The linkage between liberalism and some form of wealth transfer tax has been so strong that severing this connection seems deeply counterintuitive, and thus highlights the wisdom of rethinking basic theoretic approaches, not just to issues of taxation, but also to social theory in general. Indirectly, at least, this Article is an exercise in how tax policy analysis and political theory can learn from each other.

My argument over tax policy shall be political and interpretive. By "political," a term I am borrowing in this regard from John Rawls, I mean a style of analysis that eschews any reliance on formal, essentialist concepts like "income" or "consumption," or on "metaphysical" notions, such as of the natural rights to individual earnings or entitlements. ${ }^{8} \mathrm{~A}$ political theory of tax takes seriously the idea that legal and economic rights and institutions are human-made; that tax rules are, so to speak, up for grabs. ${ }^{9}$ By "interpretive," I mean a style of social theory that looks for norms in society's actual practices and beliefs. Interpretive theories have played a major role in judgecentric, common law fields such as torts or contracts or constitutional law, ${ }^{10}$

45 NAT'L TAX J. 119, 122-30 (1992) (discussing persistent wealth inequality and incfficacy of current wealth transfer taxes).

7. Throughout this Article, I use the terms "estate tax," "gift and estate tax," and "wealth transfer tax." The particular tax we now have is a unified "gift and estate tax," for which I use "estate tax" as shorthand, and it is an example of a "wealth transfer tax." Most of my arguments cast all forms of wealth transfer taxes into some doubt.

8. Rawls, of course, has been pursuing such a "political" theory far more generally. See JoHN RaWLS, POLITICAL LIBERALISM 11-15, 134-40 (1993) [hereinafter POLITICAL LIBERALISM]; John Rawls, Justice as Fairness: Political not Metaphysical, 14 PHIL. \& PUB. AFF. 223 (1985); John Rawls, The Law of Peoples, in ON HuMAN Rights: THE OXFORD AMNESTY LeCtures $41,42-43$ \& n.2 (Stephen Shute \& Susan Hurley eds., 1993). See generally S.A. Lloyd, Relativizing Rawls, 69 CHI.-KENT L. REV. 709 (1994) (defending Rawls' political conception against metaphysically grounded challenges). Lloyd's fine essay addresses some of the more obvious objections to Rawls' project, such that any "political" theory is predestined to accept whatever ideas are currently popular or accepted. Id. at 713-15, 731-35. The project of grounding political philosophy on a specifically political theory is not, of course, original or unique to Rawls. See, e.g., Roberto Mangabeira UnGer, Social Theory: ITS Situation and ITS TASK 151-69 (1987). Sorting through the different senses of "political" in the theoretic literature is beyond the scope of this Article.

9. UNGER, supra note 8 , passim.

10. See, e.g., RONALD DWORKIN, LAW's EMPIRE 45-86 (1986) (discussing interpretation and law); RICHARD A. POSNER, ECONOMIC ANALYSIS OF LAW 251-68 (4th ed. 1992) (interpreting common law as "implicitly" economic); see also Edward J. McCaffery, Cognitive Theory and Tax, 41 UCLA L. REV. (forthcoming 1994) [hereinafter McCaffery, Cognitive Theory] (manuscript at part II.B, on filc with author) (discussing use of interpretivism in tax policy). See generally JULES L. COLEMAN, RISKS AND 
and Rawls himself takes a decidedly interpretive turn in grounding his "political conception of justice" on "certain fundamental ideas seen as implicit in the public political culture of a democratic society." Interpretivism, however, has generally been absent from contemporary discussions of tax policy. ${ }^{12}$ The political and interpretive work hand in hand. The political freedom to seek new answers makes more important the grounding of such answers on the at least implicit ideas and conceptions of a modern democratic society, and calls for a more careful and sensitive reading of our actual practices. Careful and sensitive interpretation, in turn, helps to lead politics to reasonable answers.

At first blush, some may think that a political, interpretive theory, however well suited to other legal domains, is hopelessly out of place in the area of tax. Explicitly rejecting this view, or even detailing what I mean by a political, interpretive theory, is beyond the scope of this Article, except insofar as these points emerge implicitly, by example. Indeed, estate taxation offers an especially rich illustration of a political-interpretive theory of tax, responding crisply to at least two prominent objections. One such objection is that we cannot turn tax over to unbridled democratic politics, because the people will be predictably base and seif-interested, as James Madison foresaw clearly enough in the Federalist No. $10 .^{13}$ The principal response to this objection, of course, is that the procedural and epistemic safeguards placed on a political conception of justice-paradigmatically, Rawls' original position and veil of ignorance devices-are set up to correct for precisely this kind of narrow selfinterest off a base of existing advantages. But we do not even need Rawls' devices in the case of estate taxation, because Madison's fear has not come to pass. Part of what makes the estate tax such a fascinating example is that neither envy nor any "soak the rich" populism can explain the tax's unpopularity and its practical evisceration, here and in other democratic societies; our experience with estate taxation seems to reflect exactly the opposite-some form of anti-envy. The majority of citizens and our wellevolved practices are opposed to levying a tax exclusively on the wealthiest elite. Part of the current project is to figure out why.

A second objection is that interpretivism is unpromising in regard to tax because tax is too complex and the people are too ill informed for our implicit

WRONGS (1992) (advancing, inter alia. "middle level," or interpretuve theory of ton law). MlicuaEL. WALZER, INTERPRETATION AND SOCIAL CRITICISM (1987) (describing social cnic as interpreter)

11. POLITICAL Liberalism, supra note 8, al 13.

12. I now see my own arguments in McCaffery, Hybrtd, supra note S. as being interprelive. See also McCaffery. Cognitive Theory, supra note 10.

13. The apportionment of taxes on the vanous descriptions of property, is an act which seems to require the most exact impartality: yet. there is. perhaps, no legislative act in which greater opportunty and temptation are glven to a predominant party to trample on the rules of justuce. Every shilling with which they overburden the inferior number is a shiling saved to their own pockets

THE Federalist No. 10, at 80 (James Madison) (Clinton Rossiter ed.. 1961) 
practices to mean much of anything at all. (That these implicit practices mean simply that the people only want others, besides themselves, to pay tax is another way of putting the first point.) But the estate tax example overcomes this objection as well, at least in a prima facie way. There is nothing particularly confusing or confused about the people's opposition to the very idea of estate taxation, or about the absence of any popular clamor for more revenue on account of estate taxes. In the case of estate taxation at least, we have good reason to let the political-interpretive project go forward, to see where it leads. I shall aim for an interpretation that "fits" with our settled practices and with a reasonable, democratic conception of justice. The ultimate proof of the wisdom or attractiveness of this approach will come later, in the pudding, so to speak, of the practical recommendations that emerge.

My argument follows three basic steps: (1) The current gift and estate tax does not work, is in deep tension with liberal egalitarian ideals, and lacks strong popular or political support. (2) While the failure of the status quo may suggest a stronger wealth transfer tax as an alternative, such an answer suffers from two distinct problems: (a) a stronger tax is neither practical nor popular, and (b) given the many imperfections of the real world and the likely consequences of a strengthened transfer tax, such as reduced work, reduced savings, and increased inequality in consumption, a stronger wealth transfer tax may not be preferable even on ideal liberal grounds. (3) Motivated by the first two points to think through matters more deeply, we can arrive at alternative tax systems that both comport better with liberal first principles and fit well with the implicit spirit of our actual practices and beliefs, without any form of estate tax at all.

This argument leads naturally to a proposal for comprehensive tax reform, specifically a progressive consumption-without-estate tax. By responding to our objective preferences for work and savings while giving institutional form to our suspicions over the large-scale private use of wealth, such a tax system indeed fits best with liberal principles and with the often-inchoate spirit of our actual practices. To those who would immediately object that the private possession of wealth alone is a distinct liberal concern, not reached by a progressive consumption-without-estate tax, I hasten to add that the altered tax regime changes the very meaning, and hence the risks and dangers, of the "private possession" of wealth. The meaning of this phrase is not a constant, but rather depends on the legal rules in place. A liberal society's reasonable concerns over possession alone reduce largely to dual concerns over possession qua potential or actual use; the ability to use one's wealth, the threat of doing so. or the actual ongoing use of wealth as consumptive investment is what ought to concern the liberal. But a progressive consumption-without-estate tax, designed under a political theory of tax, changes matters by redefining property rights. In the end, it appears that our practices may be moving toward a better place, on strictly liberal grounds, than any answers that our most rarefied 
political theory alone could produce.

This Article proceeds as follows. Part II presents the traditional liberal egalitarian case for wealth transfer taxation, focusing on the work of John Rawls, and then lays the foundation for the liberal case against such taxation. Part III begins by briefly describing the current gift and estate tax law. and then analyzes how the law raises scant government revenue and adversely affects capital formation. Par IV moves to a dynamic, behavioral focus, aiming to complete the liberal case against the status quo by examining how the current regime affects inter vivos giving, work-leisure, and savingsconsumption choices, as well as by canvassing the law's general distributive consequences. Both Parts III and IV contain analytic strands questioning the wisdom and efficacy of any move toward stronger, tighter, or confiscatory wealth transfer taxes.

Turning to the Article's second major theme. Part $V$ situates the discussion in a general, comprehensive theory of tax. The central idea here is that the case against wealth transfer taxation has implications for our broadest theories of tax. In particular, both normative and interpretive reasoning support the reform proposal for a progressive consumption-without-estate tax. Normatively, this plan comports reasonably with the dictates of liberal egalitarianism-a point that emerges most strongly when we see the necessity, or at least wisdom, of taking an objective, political view of tax. ${ }^{14}$ Interpretively, the proposal fits closely with the often-inchoate tendencies of our actual practices, as these have emerged over the better part of the twentieth century. Part $V$ develops the case for this proposal. Part VI then completes the argument by criticizing two reasons to do nothing. Finally, Part VII provides a brief conclusion.

\section{The liberal Egalitarian Case for (AND Against) WEALTH TRANSFER TAXATION}

Over the years, proponents of estate taxation have advanced many reasons for the estate tax, including revenue raising, "backing up" the income tax system,${ }^{16}$ and breaking up large concentrations of wealth. ${ }^{17}$ I discuss these

14. In referring to an "objective" view. I am borrowing the term and ideas of TM Scanlon See T.M. Scanlon, Preference and Urgency, 72 J. PHIL. 655. 658-60 (1975). I have already commented above on what I mean by a "political" view. The connection is this: Scanlon's argument is that we do not simply accept subjective valuations, but take an objective vieu of the relatuve urgency of wants in rejecting a thoroughgoing, preference-based utilitarianism. Scanlon opens the door for strictly poltical arguments. I develop this theme more fully throughout the rest of this Article. especially in Pan $V$

15. Ascher. supra note 2. at 91-93: Eisenstein. supra note 2, at 238-57; see also infrat part IIl B

16. Gutman, supra note 2, at 1185-86, 1189-97. Other commentators hase offered slight vanants on this theme. See, e.g.. Henry J. Aaron \& Harvey Galper. A Tax on Consumpiton. Cufts, and Bequests and Other Strategies for Reform, in OPTIONS FOR TAX Refors 106. 111-12 (Joseph A Pechrnan cd. 1984); Graetz, supra note 2, at 284.

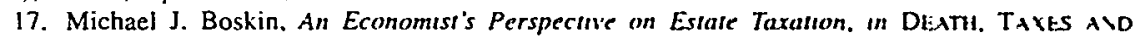
FAMILY PROPERTY, supra note 2, at 56, 65 ("(A)ny attempt to reduce (substantually) inequalit) in the distribution of wealth via estate and gift taxation is doomed to faslure I see a much less ambitious 
rationales, all of which are of questionable justificatory strength when held up against the reality of the existing legal regime, in passing. ${ }^{18}$ In contrast, support for the estate tax has drawn its greatest strength from philosophical foundations and intuitions, recently advanced by such liberal egalitarian political theorists as John Rawls, ${ }^{19}$ Ronald Dworkin, ${ }^{20}$ and Bruce Ackerman. ${ }^{21}$ I proceed directly to these philosophical arguments to set out the liberal case for wealth transfer taxation.

There are, of course, important differences among liberal theorists, for example with regard to how strongly they orient themselves toward a rightsbased, deontologic position, as opposed to allowing consequentialist considerations to shape the institutions of justice. Liberal theorists also differ in the extent and nature of their solicitude for actual practices. For most purposes, however, I shall call them, collectively and generally, "liberal egalitarians."22 An important point of commonality is that all liberal egalitarians see intra-generational uses of wealth in a different light than intergenerational transmissions. ${ }^{23}$ While they uphold a range of principles, they all tend to emphasize equality of starting points and fairness in socioeconomic institutions. Liberal egalitarians typically are willing to allow intra-generational outcomes to diverge considerably, as persons make different choices in the use of their initial endowments in just transactional settings. ${ }^{24}$

Inter-generational transmissions of wealth, however, pose other, more troubling problems for the liberal egalitarian. Ackerman, for example, argues at some length that such transmissions fatally interfere with the equality of starting points. ${ }^{25}$ Liberal egalitarians who call for confiscatory estate taxation

role for these taxes: preventing extreme concentrations of wealth from being passed from generation to generation."). A useful catalog of other reasons for estate taxation is provided by Duff, supra note 2.

18. See also Donaldson, supra note 1, at 539-50 (criticizing popular justifications for current gift and estate taxation).

19. See generally JOHN RAWLS, A ThEORY OF JUSTICE (1971) [hereinafter ThEORY OF JUSTICE].

20. See, e.g., RONALD DWORKIN, A MATTER OF PRINCIPLE 207-08, 269-71 (1985) (hereinafter Dworkin, MatTer of PRINCIPLE]; Ronald Dworkin, What is Equality? (pts. I \& 2), 10 PHIL. \& PUb. AFF. 185, 283 (1981).

21. See generally BRuCE A. ACKerman, SOCIAL JustiCE IN THE LIBERAL STATE (1980) [hereinafter SOCIAL JUSTICE]. For additional views of other liberal theorists, see generally JAMES S. FISHIKIN, JUSTICE, EQUAL OPPORTUNITY, AND THE FAMILY (1983); MUNZER, supra note 6; Haslett, supra note 3.

22. See Will KYMLICKA, CONTEMPORARY POLITICAL PhILOSOPHy 50-94 (1990) (discussing "libcral equality" as philosophical school characterized by Rawls).

23. For another statement of this political-philosophical approach, see generally ERIC RAKOWSKI, EQUAL JUSTICE (1991). For a discussion of wealth transfers, see id. at 149-66.

24. Ackerman puts the case in general language that is perhaps more evocative than any specific examples can be:

[I] the end there will be a great disparity in personal histories. Some will have used the transactional system to gain enormous wealth; others will die with nothing but their name. Some with few material possessions will exercise great moral leadership . . . others will amass material fortunes to find themselves the objects of widespread contempt. Still others are solitary and poor-some brutish, some wise.

SOCIAL JUSTICE, supra note 21 , at 201. Given the twin conditions of fair entitlements and just institutions (the "transactional system," in Ackerman's phrase), these disparities are all fair play.

25. Id. at 202-27. 
tend to follow this line of argument. ${ }^{26}$ This sort of objection has even led the libertarian Robert Nozick to back off from his earlier claim that bequests represent a fair use of resources, a "right" of the donor that raises no distributive concerns, given an initially fair starting point. ${ }^{27}$ Nozick now concedes that we should place some limits on the power to make bequests. ${ }^{28}$

This liberal egalitarian perspective led Rawls to suggest a rather precise tax system in A Theory of Justice. It is helpful to have this tax plan before us, because it represents the best concrete form of the liberal egalitarian ideal, and it highlights the strongest case for wealth transfer taxation. Rawls' system entails a proportionate, or, equivalently, a flat-rate consumption tax, coupled with a steep, although not confiscatory, ${ }^{29}$ bequest or inheritance tax. The flatrate consumption tax follows the pattern of solicitude toward intra-generational outcomes. It is significant that Rawls qualifies his support for this aspect of the plan with the assumption that "income is fairly earned"; Rawls sees these general taxes primarily as a way to raise revenue, and he presumes that fairness in market outcomes has already been achieved. ${ }^{30}$ Rawls advocates bequest or inheritance taxes, on the other hand, "not to raise revenue . . but gradually and continually to correct the distribution of wealth and to prevent concentrations of power detrimental to the fair value of political liberty and fair equality of opportunity."31 Rawls also explicitly allows for inheritance, subject to his general principles of justice: "[I]nheritance is permissible provided that the resulting inequalities are to the advantage of the least fortunate and compatible with liberty and fair equality of opportunity." ${ }^{32}$ This interesting qualification opens the door to consequentialist arguments, or at least a consideration of consequentialist effects, not readily made under the more rights-oriented liberal egalitarian approaches, such as those set forth by Ackerman or by recent scholars calling for confiscatory inheritance taxes."

As the selective quotations from Rawis indicate, the liberal egalitarian case

26. See, e.g., Ascher, supra note 2, at 88-91: Haslelt, supra note 3, at 137-55

27. ROBERT NOZICK. ANARCHY, STATE. AND UTOPIA 150-53. 155-58 (1974)

28. Robert Nozick. The Examined Life: Philosophical Medtanons 30-33 (1989) Nozich's new plan is actually similar to one proposed much earlier in the century by the Italıan financier Emest Rignano, which involved higher levels of aceession taxes on more remole descendants See KIESLIVG. supra note 2, at 157-59 (discussing Rignano-type plans): John K. MicNulty. Fundamental dlternutives to Present Transfer Tax Systems, in DEATH. TAXES AND FAMILY PROPERTY, supra note 2. al 85. 87-89 (discussing Rignano's plan).

29. THEORY OF JUSTICE, supra note 19, at 277-79. Raw/s reiterates virtually all of his tax-related proposals in his widely circulated manuscript, John Rawls. Justuce as Famess: A Restatement 130-31 (1990) [hereinafter Justice as Fairness] (unpublished manuscript. on file with author). where he makes clear his correct understanding that "consumption" and "expenditure." and "proportionate" and "flat-rate," are equivalents.

30. THEORY OF JUSTICE, supra note 19, at 278-79: see also id. at 279 (discussing tax systems under nonideal theory).

31. Id. at 277

32. Id. at 278 .

33. See generally Ascher, supra note 2 (calling for end to inheritance or for "confiscatory" transfer taxes); Haslett, supra note 3 (same). 
for some form of wealth transfer tax is intimately linked with the "fair equality of opportunity" ideal. This principle, technically first set forth as a part of the second aspect of Rawls' second principle of justice, ${ }^{34}$ holds that people of equal abilities and aptitudes "should have the same prospects of success regardless of their initial place in the social system, that is, irrespective of the income class into which they are born." 35 Rawls does not claim, either in the passages setting forth fair equality of opportunity or in his sketch of an ideal tax system, that the institutions of society should be set up to ensure that individuals in fact be born into the same "income class." Rather, Rawls has the comparatively more modest concern that unequal income classes should not adversely affect important life opportunities or "prospects of success." 36 Rawls clearly is concerned, however, that unfettered rights to inherited property can interfere with even this more flexible and modest notion of fair equality of opportunity. In setting out an equal-opportunity ideal that is distinct from equality of outcome or result, and in seeing some form of wealth transfer tax as a central institutional embodiment of the equal-opportunity ideal, Rawls is well within a characteristically American liberal egalitarian tradition. ${ }^{37}$

It is also interesting to note that in his recent Political Liberalism, ${ }^{38}$ which is on several levels a refinement and extended commentary on $A$ Theory of Justice, ${ }^{39}$ Rawls clarifies what might have been only implicit in his earlier work: The fair-equality-of-opportunity norm does not yield determinate institutional answers. Rawls concludes that the entire fair-equality-ofopportunity principle does not rise to the level of a "constitutional essential": "[W]hile some principle of opportunity is surely such an essential, for example, a principle requiring at least freedom of movement and free choice of occupation, fair equality of opportunity (as I have specified it) goes beyond that and is not such an essential." 40 In generally discussing the principles "covering social and economic inequalities," Rawls now states that "[t]hese matters are nearly always open to wide differences of reasonable opinion; they rest on complicated inferences and intuitive judgments that require us to assess

\footnotetext{
34. See THEORY OF JUSTICE, supra note 19 , at 60-75.

35. Id. at 73; see also id. at 83-90, 299-303.

36. Id. at 73.

37. See Social JUSTICE, supra note 21, at 43-45, 107-09, 202-07; DWORKIN, MATTER OF PRINCIPLE, supra note 20, at 187, 191-96, 205, 206-07; see also FISHKIN, supra note 21, at 50, 51-55.

38. POLITICAL LIBERALISM, supra note 8.

39. Id. at $x v-x v i$. Rawls writes:

Indeed, it may seem that the aim and content of these lectures mark a major change from those of Theory. . . But to understand the nature and extent of the differences, one must see them as arising from trying to resolve a serious problem internal to justice as fairness, namely from the fact that the account of stability in part III of Theory is not consistent with the view as a whole. I believe all differences are consequences of removing that inconsistency. Otherwise these lectures take the structure and content of Theory to remain substantially the same.
} Id.

40. Id. at 228. 
complex social and economic information about topics poorly understood."Nit The cursory musings on tax structure in A Theory of Justice are absent from Political Liberalism; Rawls now sweeps tax aside with the single reference that "[m]any if not most political questions do not concern . . . fundamental matters, for example, much tax legislation and many laws regulating property." ${ }^{12}$ Rawls seems to have realized that the transition from ideal theory to real prescription is even more difficult than he had envisioned at the time of $A$ Theory of Justice; he now distances himself from those "hunches" put forth two decades earlier. ${ }^{43}$ Alternatively, Rawls may have come to appreciate the unavoidably political nature of questions of tax, as I shall discuss throughout this Article.

The subtle transition in tax philosophy from A Theory of Justice to Political Liberalism, admittedly an issue to which Rawls devotes little space in either work, sets an appropriate stage for this Article. I am pursuing the particular questions concerning wealth transfer taxation in depth, in part to see how "complex social and economic information" speaks to questions of tax design under liberal first principles. Far from taking exception to Rawls or to liberal egalitarianism more generally, I explore how we might better implement a liberal vision in practice. My claim is that the result of this essentially normative inquiry may be counterintuitive to first impressions derived from liberal theory alone. At a minimum, this possibility illustrates the wisdom of Rawls' caution in addressing questions of social and economic inequalities; ${ }^{* *}$ it also helps show how a thoroughly political social theory can lead to some surprising results.

Specifically, I level five distinct though related criticisms of the general liberal egalitarian support for the estate tax. Each of these arguments accepts the moral and ethical bases of liberal egalitarianism. say of the Rawlsian variety, but questions the fit between liberalism in theory and wealth transfer taxation in practice. I aim to establish that alternative comprehensive lax systems that do not incorporate any form of an estate tax can both better protect prior liberties and improve the welfare of the lower classes; that reasonable citizens acting under conditions of mutual freedom and equality would concur; and that, in fact. actual citizens have concurred.

41. Id. at 229.

42. Id. at 214 .

43. See THEORY OF JUSTICE. supra note 19. at 278 (arguing that sellung practical line in lumung matters such as inheritance "is a matter of political judginent guided by theon. good senes. and plaun hunch. at least within a wide range"): see also id. at 279 (excluding other tax detalls from his theory of justice).

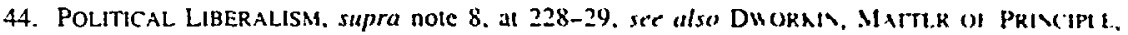
supra note 20, at 207 ("Obviously any practucal program claming to respect both these principles fof meritocracy and equal opponunityl will work imperfectly and will inevitably involve speculation. compromise, and arbitrary lines in the face of ignoranec", Buf of Brute Acherman. Polutual Liberalisms, 91 J. PHIL. 364, 371-75 (1994) (cntucizing Polific al Luberalesm for baching off of elaıms concerning economıc and social inequality). 
First, the current income-plus-estate tax system undercuts its own best theoretical support. Liberal egalitarianism is concerned with, among other goals, mitigating unequal starting points. The actual gift and estate tax regime, however, encourages frequent, large, inter vivos gifts, systematically excluded from the income tax base, and it thus can dramatically undermine the pursuit of equal opportunity and level playing fields. ${ }^{45}$ When combined with the sizable gaps in our major intra-generational tax, the nominal income $\operatorname{tax}^{46}$ the existing tax system results in large intra-generational wealth disparities and even encourages the inter-generational transmission of this disparate wealth. I illustrate this point both by discussing the doctrinal features of the income and estate tax regimes that facilitate this counterproductive result, and by attempting to establish the facts of significant inter vivos wealth transmission. Further, the current, and indeed any, wealth transfer tax encourages consumption, or the personal use of wealth. But consumption by the very wealthy turns out to be a particular liberal problem, as I argue more fully below. In encouraging inter vivos gifts and large-scale consumption by the rich, the current estate tax is illiberal.

Second, no feasible wealth transfer taxation system, under both practical and political constraints, can support the liberal egalitarian ideal. This point extends the factual first point into a more theoretical, though practically situated, impossibility theorem. I illustrate this argument in several ways. I point out the doctrinal difficulties in moving toward a confiscatory tax, underscoring the exceptions allowed and their potentially severe consequences. I discuss the unpopularity of stronger, more widespread wealth transfer taxation in the United States, along with the recent repeals of estate or inheritance taxes in Australia, Canada, Israel, and California. I also discuss emerging theories and evidence on why and how people save, which suggests that the majority of savings may be inter-generational in character, indicating that a strong wealth transfer tax system runs counter to deep-seated human motivations. Finally, I point out that any wealth transfer tax encourages inter vivos giving, consumption, or both.

These first two arguments are narrowly practical. The third and fourth arguments question the wisdom of a wealth transfer tax on purely liberal grounds, even if such a tax were practically feasible; for these arguments, we can posit an improved estate tax. The third argument is that even such an improved tax is inappropriate in a nonideal world. Neither of the background conditions of the liberal egalitarian, equal-opportunity model-equal initial entitlements and just social institutions-materialize in the real world. The fact of ongoing inequalities ironically makes the role of wealth transfer taxation

45. See infra part IV.A.I.

46. As I discuss further in Part $\mathrm{V}$, what we persist in calling an income tax is in fact a complex income-consumption hybrid. See generally McCaffery, Hybrid, supra note 5. 
more complex and more contestable than it might at first appear." Once we have moved away from simple merit-based assumptions, such as the idea that one is entitled only to whatever she has personally "earned," any middle ground becomes a bit uneasy. As noted above, the current, ineffective system of wealth transfer taxation may exacerbate intra-generational inequality by encouraging large inter vivos transmissions and increased consumption by the rich. A confiscatory wealth transfer tax, on the other hand, would result in even greater inequality in consumption, as well as diminished savings. These effects might predominantly harm the lower classes both by interfering with prior liberties, as large-scale consumption by the rich may well do, and by lowering general standards of living, as diminished capital would almost certainly do. In contrast, allowing inheritance might improve the fate of the least-well-off class, especially if certain safeguards on the use of wealth were put into place, without interfering with liberal principles such as the fair equality of opportunity. The practical liberal egalitarian ought to look for alternatives to wealth transfer taxation, as well as at the possibility of a better balance between intra- and inter-generational norms.

Fourth, it is possible to make out a strong argument against wealth transfer taxation sounding in ideal theory. The traditional liberal egalitarian tax scheme, as envisioned by John Stuart Mill and Rawls, ${ }^{48}$ rests largely on an individualist or subjectivist ethic. This tax scheme presumes that individuals are entitled to their "earnings," but views the private possession of "unearned" wealth as uniquely and particularly inimical to, or at least in severe tension with, liberal egalitarian values. While my third argument questions the role of a wealth transfer tax in a world where the factual basis for "earnings" has come into doubt, my fourth argument is that, even if wealth is indeed "fairly earned," society may nonetheless have objective, political reasons for opposing estate taxation. Simply put, and finessing metaphysical questions over deser and entitlement, liberal society likes earnings and savings, both of which

47. Dworkin appears to have seen this point most clearly. or at least (charactenstically) put the matter most eloquently:

[A liberal's] theory of economic justuce must be complex, because he acepts ino principles which are difficult to hold in the administration of a dj namic economs The first requires that people have, at any point in their lives, different amounts of wealth insofar as the genuine choices they have made have been more or less expensive or bencficisl to the community .... The second requires that people not have different amounts of wealth just because they have different inherent capacities to produce what others want, or are differently favored by chance. This means that market allocations must be corrected in order to bring some people closer to the share of resources they would have had but for these sanous differences of initial advantage. luck. and inherent capactly

DWORKIN, MATTER OF PRINCIPLE, supra note 20. at 207 Duorkin contunues to note the practical difficulties of implementing any liberal program balancing these two principles $l d$ at 207-a8

48. See John Stuart Mill. PRINCIPles of Political. ECONomy 808-13 (J il Robson ed. 1965) (1848) (advocating proportionate income tax with base-level exemption) Rawls does qualify his opinion in A Theory of Justice with the comment. "It does not follow that. given the injustice of existing institutions, even steeply progressive income taxes are not justified when all things are considered" THEORY OF JUSTICE, supra note 19. at 279. 
contribute to a certain metaphoric "common pool," and only or at least especially suspects use, particularly the large-scale, rapid dissipation of capital by the wealthy. Earnings and savings each represent goods to the liberal majority, whereas use represents an individual imposition on the collective and is therefore not a liberal good. Put conversely, claims of inequality are most compelling vis-à-vis the use of resources; the justice of earnings is logically and ethically distinct from the justice of use. Furthermore, large-scale use may distort the allocation of resources and interfere with the fair value of prior liberties; it is the use and not the mere concentration of wealth that threatens reasonable liberal values. But because any wealth transfer tax is a tax on possession alone that encourages use and penalizes earning and saving, especially by the very wealthiest citizens, it is perverse on strictly objective, political grounds.

On this view, wealth transfers from the wealthy may even be, ironically, the preferred liberal result. Because liberal society likes earnings and savings on objective political grounds, but does not like excessive private use, it must allow the rich to pass on their wealth: Something has to give. This argument leads to the strongest condemnation of the reigning liberal tax policy wisdom, which has consistently advocated progressive income and wealth transfer taxes. By getting our reasonable political judgments wrong-by taxing work and savings while condoning, even encouraging, large-scale use-the status quo impedes the liberal project. Even under the most basic, static conception of progressive redistribution, an income-plus-estate tax is a poor option because it compels liberal society to choose between progressivity and objective goods, i.e., work and savings. In contrast, a consistent, political focus on use changes the very meaning and hence the dangers of private "possession," responding to the liberal egalitarian's equal-opportunity concern over the mere ownership of resources. The real threats to liberty and equality from private possession alone turn out, on closer scrutiny, to relate to possession qua potential or actual use, each of which can be addressed-indeed, can best be addressed-in a tax system without an estate tax.

Both the third and fourth arguments cast a different light on popular resistance to estate taxation, which informed the first two arguments. Now it appears-mirabile dictu! - that the people just might be right in opposing the estate tax, on liberal grounds. I now arrive at my fifth argument: The best feasible liberal tax system features no wealth transfer tax at all. The plan that I believe best responds to liberal egalitarian ideals, as mentioned above, is a progressive consumption-without-estate tax. Such a plan can include a special rate structure on inherited wealth that, in principle, will achieve some of the effects desired by advocates of wealth transfer taxation and begin to blur positivist distinctions between tax forms. Whereas any estate tax encourages use and punishes thrift, a progressive consumption tax appropriates "private" wealth at precisely the moment when an individual is about to use it 
excessively for personal purposes. The proposal thus goes a long way toward redefining the very concept of possession that has concerned liberal egalitarians; it takes away the unfettered right to rapid, large-scale use of "private" funds. We can also insist that the "private" wealth accumulation that is encouraged by the plan be invested in socially approved or regulated vehicles, designed to address the dangers of consumptive investment. We could design these vehicles, akin to pension plans or the government regulation of the nonprofit, charitable sector. so as not to lose all of the efficiency gains of private capital, while making literal the public claims on the wealth. The proposal thus looks to forge a convergence between liberal egalitarian theory and our actual practices; it is grounded both in independent normative analysis and interpretive theory.

The five arguments can now be summarized and related as follows. (1) The current estate tax is porous, ineffective, and counterproductive on purely liberal grounds. (2) No stronger version is popular or practical, in part because (3) the liberal theory supporting an estate tax does not lit in a nonideal world where individual earnings lack presumptive, decisive moral weight, and in part because (4) our objective, political values, even under ideal conditions, lead liberal society to approve of work and savings and only or at least especially to disapprove of the wanton private use of resources. and any wealth tax is perverse on these scores. (5) Therefore, our practices have been moving, at least inchoately, toward a progressive consumption-without-estate tax. If we more consciously and consistently implemented what our practices suggest, we would have a better liberal egalitarian system than any featuring a wealth transfer tax. By meeting our objective values and changing the very meaning and hence the dangers of the private possession of wealth, we achieve in the end a happy convergence between liberal egalitarian theory and our actual practices.

\section{The Estate Tax: Law, Effects, and Consi:qlinces}

This Part sets out the basics of the current gift and estate tax law and then discusses its possible economic effects on revenue and capital formation. This discussion of the law and its effects begins the extended examination of our actual practices that will provide much of the substance underlying both the ultimate critique and the alternative positive program.

\section{A. The Law}

Most people do not have to think about the complex gift and estate tax regime that now exists in the United States. Taxes potentially begin to apply only when the sum of includable lifetime gifts and testamentary bequests 
exceeds $\$ 600,000$ per donor. ${ }^{49}$ Gifts that fall within the "annual exclusion rule" of up to $\$ 10,000$ per donee per donor per year do not count against the total..$^{50}$ Most transfers to a spouse,,$^{51}$ payments for educational or medical needs, ${ }^{52}$ and charitable gifts ${ }^{53}$ are also excluded. Until a married couple accumulates an estate approaching $\$ 600,000$, they hardly need to consider gift and estate taxes at all. Once a couple reaches this threshold, the husband and wife need proper planning to ensure that each uses his or her exemption amount, for a total household threshold of $\$ 1.2$ million..$^{54}$ For couples near this level, there are various tactics for avoiding the sting of the tax, ranging from simple use of the annual exclusion gifts to more sophisticated strategies. ${ }^{55}$ When all is said and done, only about $1 \%$ of decedents leave an estate with any estate tax liability. ${ }^{56}$

Yet it is also true that, for couples or individuals well over the relevant thresholds, the estate tax can be quite a large burden indeed. Rates begin at $37 \%$ and rise rather quickly to $55 \%$. There is a fairly substantial "phase-out" range in which the estate tax rate hits $60 \%$, and the net effect for the very wealthy is a flat rate of $55 \%$ above the exemption level. ${ }^{57}$ Some key statistics illustrate the burden of the estate tax on the very rich. In 1991, the estate tax raised $\$ 9.1$ billion. More than half of this amount, almost $\$ 4.7$ billion, came from taxpayers with gross estates over $\$ 5$ million, even though such estates represented only 1420 of the 24,761 taxable returns (less than 6\%). ${ }^{58}$ Table 1 shows the average estate tax paid by a taxable estate in each of three high wealth ranges:

49. In terms of the statute, one derives this number from the rate schedule set out in I.R.C. $\$ 2001$ (1994), plus the "unified credit" provided by I.R.C. $\$ 2010$, and the unification of the gift and estate tax evidenced by I.R.C. $\S 2502$. There has been some discussion lately about lowering this threshold level.

50. Id. $\S 2503(\mathrm{~b})$.

51. Id. $\$ 2056$ (estate tax); id. $\$ 2523$ (gift tax). The reason for the qualification to "most" transfers is the rather technical rules governing partial interests in property conveyed to a spouse.

52. Id. $\S 2503(\mathrm{e})$. The educational exclusion extends to qualified tuition payments only. Id. $\S 2503(\mathrm{e})(1)$.

53. Id. § 2055 (estate tax); id. § 2522 (gift tax).

54. The reason that proper planning is necessary is that without it, the surviving spouse will simply inherit from the other spouse and will be left with only her or his own exemption amount.

55. A dated but still useful source is COOPER, supra note 2. Planning points can be found in many sources. See, e.g., MYRON S. SChOlES \& MARK A. WOLFSON, TAXES AND BUSINESS STRATECY: A PlanNING APPROACH 575-608 (1992); C. David Anderson \& Nancy E. Howard. The Mathematics of Estate Planning and Estate Freezing, in Estate FREEZING: TOOLS AND TECHNiQues 7-1 (Douglas K. Freeman ed., 1985).

56. See Barry W. Johnson, Estate Tax Returns, 1989-199/, in INTERNAL REvenUe SERV., STATISTICS OF INCOME BULleTIN, Spring 1993, at 76, 76-81. The report notes that $2.3 \%$ of U.S. decedents had gross estates that exceeded $\$ 600,000$ in 1989 and thus filed an estate tax return. Id. at 76 . More than half of these, however, paid no tax, largely because of the marital deduction. See infra note 62 and accompanying text.

57. I.R.C. $\S 2001$ (c).

58. See Johnson, supra note 56, at 88-91 tbl. 1. 


\begin{tabular}{|c|c|}
\hline Size of Gross Estate & Average Estate Tax \\
\hline$\$ 5-10$ million & $\$ 1.7$ million \\
\hline$\$ 10-20$ million & $\$ 3.2$ million \\
\hline over $\$ 20$ million & $\$ 10.1$ million \\
\hline
\end{tabular}

TABle I. Average Estate Tax Paid, by Size of Estate, 1991

The figures for average estate taxes paid are clearly significant, even to the very wealthy families who are the only ones paying them.

Once comfortably within the estate tax's reach, a person has only limited techniques for avoiding the tax. To have a real example before us throughout our discussions, let us consider the case of $\mathrm{H}$. Ross Perot, whose personal net worth is estimated at $\$ 3$ billion. ${ }^{59}$ If a taxpayer of Mr. Perot's wealth is at all concerned with the tax, he will have a strong incentive to minimize the size of his estate by aggressively using his annual exclusion gifts and unified credit amount, and he may go even farther by engaging in a pattern of inter vivos, taxable gifts. ${ }^{60}$ Otherwise, Mr. Perot has three basic choices: (1) he can give the money to charity, now or upon his death; (2) he can bequeath $45 \%$ of the money to his children or other noncharitable beneficiaries and incur an estate tax of 55\%; or (3) he can spend the money. ${ }^{61} \mathrm{Mr}$. Perot can combine any of these strategies. By using the "marital deduction," he can postpone the tax or charitable contribution until the later of his or his wife's death. ${ }^{62} \mathrm{He}$ can also engage in various strategies, some of them of dubious propriety, to reduce the

59. Actually, there is some uncertainty about Perot's net worh. One estimate puts it at "at least $\$ 24$ billion." Billionaires, FoRBES, Oct. 18, 1993, at 112, 121. A media eslumate from Mas 1992, contimed by a Perot campaign official as accuratc, was $\$ 3.3$ bilion. Randall Lane. What's Ross Reall, Worth? FORBES, Oct. 19, 1992, at 72. I assume a net worth of $\$ 3$ billion, although nesther of the other tigures would alter Perot's marginal incentives. The Perot example in part suggests that all consumption expenditures under a back-ended wealth tax share the structure of "tax expenditures" under an income tax. That is, the government loses money by virtue of taxpayer action. When an individual receives a nontaxable fringe benefit, for example, the tax expenditure logic argues that the government has thereby foresworn revenue that it would have received had the iaxpayer received ordinary salary instead The same is true whenever a wealthy taxpayer consumes under a back-ended wealth tax This wealth would have been subject to a $55 \%$ estate tax but for the expense. and we could therefore thinh of this as a "tax expenditure." (There is no need to engage in any present value discounting of the tax burden. because if the wealth were not consumed it would presumably grow at the discount rate). I mean to avoid any lengthy discussion of the normative status of various clatms under traditional tax expenditure analysis. which would lead us too far astray in an already weighty project. See generalls STANLEY S St RREY \& PAul R. MCDANiel, TAX EXPENDITURes (1985); Boris 1. Bittker. The Tax Expendirure Budget-A Reply to Professors Surrey and Hellmuth, 22 NAT'L TAX J. 538 (1969) (cntucizing tax expenditure analysis)

60. See discussion infra part IV.A.I.

61. By "spend," I mean a final use of resources-1 c.. spending by dining in fine restaurants or traveling the world, as opposed to "spending" on assets, such as yachis. that would then stay in the estate. Of course, the depreciation in value of assets like cars, yachis, and houses would count as estate. tax-avoiding "spending." See, e.g.. William D. Andrews. A Consumphon-Tipe or Cash Flow Personal Income Tax, 87 HARV. L. REV. 1113. 1155-57 (1974) (hereinafter Andreus. Consumphon-Type] (discussing treatment of "consumer durables" under a consumption tax ideal)

62. I.R.C. $\S 2056$ (1994). 
perceived value of his estate. ${ }^{63}$ These latter techniques are not necessarily anything to sneeze at: Taxpayers and their advisors spend a good amount of time and money devising strategies to avoid the estate tax.

At some quantum of wealth, and barring a change in the tax laws, these choices become the only meaningful ones available to the truly wealthy taxpayer. To the extent that such taxpayers are altruistically inclined or able to create nonaltruistic linkages across generations, ${ }^{64}$ the law encourages frequent, early, and generous use of all available exceptions, which can result in the transmission of sizable fortunes inter vivos. At the same time, the law discourages work and savings and encourages large-scale spending among the rich. While the government has a large stake in all of these decisions, the current law constrains it to wait by idly to see how it all comes out.

\section{B. Revenue Effects}

The revenue effects of the gift and estate tax regime are certainly not my major concern. Nevertheless, a discussion of these effects nicely frames the analysis, in part because some commentators have relied specifically on revenue-raising as a principal justification for estate taxation..$^{65} \mathrm{~A}$ discussion of revenue effects also illustrates the practical and political limits of the estate tax, and it moves us further into a consideration of empirical and behavioral issues. To that end, this Section examines revenue effects in a cash-flow or partial-equilibrium sense. ${ }^{66}$ That is, I shall look to immediate, observable consequences without accounting for any long-term, dynamic, or behavioral responses that would further complicate matters. A partial-equilibrium analysis, for example, assumes that the tax rate or structure will not affect basic individual decisions regarding work versus leisure or savings versus consumption, and so on.

The strongest way to see that revenue is not the central concern is to consider the claim that the gift and estate tax might actually be losing money

63. For example, Mr. Perot could create a difficult-to-value family business and use common law principles such as "minority discounts" to get excess value out of his estate. See generally COOPER, silpra note 2 (criticizing estate tax as easily avoidable); SCHOLES \& WOLFSON, supra note 55 (discussing various tax avoidance strategies). This point illustrates other biases generated by an estatc tax-loward certain types of assets and certain forms of ownership.

64. See discussion infra part IV.A.I.

65. See Ascher, supra note 2, at 93 ("Depriving rich parents of the right to decide who will own their property after death is a similarly painless and appropriate way to raise revenue."); see also MILL. supra note 48, at 822; Eisenstein, supra note 2, at 238-52, 256-57. See generally JEREMY BENTHAM. SUPPLY WITHOUT BURDEN (1795), reprinted in 2 THE WORKS OF JEREMY BENTHAN 585 (John Bowring ed., New York, Russell \& Russell, Inc. 1962).

66. The next section, Part III.C, broadens this discussion by relaxing the ceteris paribus assumption to determine the real, bottom-line revenue effects of having a wealth tax in place. Specifically, Part III.C adds potential capital stock effects to the mix. Because the analysis in Part III.C covers many other issues, I have chosen to separate it structurally from the more narrow discussion of short-term revenuc effects contained here. 
for the government. The federal government may collect more revenues from repealing the tax, regardless of any indirect effects through variables such as work effort or the capital stock. Proof of this claim, of course, does not alone doom the estate tax under the liberal egalitarian ideal, although it would indeed raise troublesome questions and knock out at least one basis for the tax's support; Rawls, for example, explicitly advocated wealth transfer taxes "not to raise revenue." ${ }^{67}$ But a practical, commonsensical wisdom might make us skeptical of taxes that do not raise revenue, even if the very absence of revenue may sometimes suggest that the tax is working-as conceivably ought to be true in the case of "sin" taxes on cigarettes and alcohol.

Why might the gift and estate tax regime lose money every year? Begin with the fact that the actual yield of the taxes is low. Gift and estate taxes brought in $\$ 7.6, \$ 8.7$, and $\$ 11.5$ billion in 1988, 1989, and 1990, respectively. Although these numbers might seem large, they represent only $0.2 \%$ of gross domestic product (GDP) and less than $1 \%$ of federal revenues for the years in question. ${ }^{68}$ (The jump in revenues between 1989 and 1990 was largely due to increased gift taxes, itself an interesting development that I discuss below.) These taxes have always had a low yield, despite their high marginal rates. While gift and estate taxes once accounted for a larger share of total federal revenues, their share of GDP has always been meager, although, to be sure, both of these values are now below their historic highs. ${ }^{(9)}$

67. THEORY OF JUSTICE, supra note 19, at 277: sec also supra note 31 and accompanying text.

68. During the years 1988. 1989, and 1990. gift and estate tax receipts as a percentage of total federal government receipts were $0.836,0.878$. and 1.12 , respectuvely $A$ s percentages of gross domestic product, the figures were $0.159,0.169$, and 0.213. respectively. See OFFCE OF MANAGEMLST \& BLDGET, Budget of the United States GovernMent. Fiscal Year 1992. Historical Tablis, tbls. 1.1, 13 , 2.5 (1991) [hereinafter HISTORICAL TABLES].

69. The following table shows the changing magntudes of the gift and estate tax burden over tume

\begin{tabular}{|c|c|c|c|}
\hline Year & $\begin{array}{c}\text { Taxes Paid } \\
\text { (\$ millions) }\end{array}$ & $\begin{array}{c}\text { F Federal } \\
\text { Revenue }\end{array}$ & $\begin{array}{c}\text { GC }_{c} \\
\text { GDP }\end{array}$ \\
\hline 1940 & 353 & 539 & 0366 \\
\hline 1945 & 637 & 141 & 0.300 \\
\hline 1950 & 698 & 177 & 0.262 \\
\hline 1955 & 924 & 1.41 & 0.239 \\
\hline 1960 & 1606 & 1.74 & 0.318 \\
\hline 1965 & 2716 & 2.37 & 0.405 \\
\hline 1970 & 3644 & 1.89 & 0.369 \\
\hline 1975 & 4611 & 165 & 0.302 \\
\hline 1980 & 6389 & 1.24 & 0.240 \\
\hline 1985 & 6422 & 088 & 0163 \\
\hline 1990 & 11.500 & 112 & 0213 \\
\hline
\end{tabular}

TABLE 2. Gift and Estate Tax Revenues. 1940-1990 
From this humble base, we ought to subtract the administrative costs of collecting the tax. I was unable to generate an actual figure for the cost of administering the estate tax, and the IRS itself could not furnish the statistic. Nevertheless, the figure is apt to be substantial. ${ }^{70}$ The estate tax is expensive to monitor. Questions of valuation and ownership structure are persistent and complex, and taxpayers often choose to litigate because of the large stakes and the basic indeterminacy of the valuation and other questions involved. The IRS maintains a separate estate tax examination unit in each of its district offices. Congress has also devoted considerable time and attention to this area of the law recently. ${ }^{71}$ The government's costs, whatever they are, obviously reduce the estate tax's effective yield.

In addition, tax avoidance incentives might lead to more significant losses. Commentators have long noted the plethora of planning devices that have made the estate tax "voluntary." These induced transactions come with their own revenue and normative costs. The economist Douglas Bernheim has argued that the transactions generated by an awareness of the estate tax lose more revenue for the government, in the form of forgone income tax receipts, than the gift and estate tax regime raises. Bernheim's original model proceeded under the greater rate-bracket discrepancies obtaining before 1986, although he did update it to include the 1986 changes. The main conclusion of his model is that charitable donations and gifts from high-bracket taxpayers to lowbracket taxpayers, each motivated at least in part by the estate tax, cost the government significant income tax revenues. ${ }^{73}$

Bernheim's story is complicated to prove, and his conclusions are in some ways overstated. One must establish that the extra estate tax savings caused private parties' saving in income taxes, which roughly would mean that own consumption is preferred to other consumption by more than the income tax margin but by less than the combined income and estate tax one. ${ }^{74} \mathrm{~A}$ variant

These numbers indicate that, while the yield of gift and estate taxes is no doubt below its historic high, it has always been rather meager, and that looking only at the taxes as a percentage of revenue overstates their magnitude. For an example of a commentator who focuses on the percent of revenue figure, sce Eisenstein, supra note 2. Because there is no indexing of the unified credit or rate brackets under the gift and estate tax, the rates tend to trend upwards after reforms. For example, budget estimates for the years 1991 and 1992 predicted that the tax as a percentage of GDP would increase to 0.218 and 0.222 , respectively. See HISTORICAL TABLES, supra note 68, tbls. 1.1, 1.3, 2.5. In fact, the actual gift and estate tax collections as a percentage of GDP for 1991, 1992, and 1993 were $0.196,0.188$, and 0.2 , below the estimates. OFFICE OF MANAGEMENT \& BUDGET, BUDGET OF THE UNITED STATES GOVERNMENT, FISCAL. YEAR 1995: HistoricAL TABLES, tbls. 1.2, 2.5 (1994).

70. See, e.g., Donaldson, supra note 1, at 548-50 (discussing various costs of gift and estate tax): Hudson, supra note 1 , at 32 (discussing difficulty of measuring costs).

71. Donaldson, supra note 1. at 548-49; see also Robinson, supra note 2, at 44 (suggesting that legislative attention should shift away from estate taxes to other, more pressing, problems); $c f$. Janct Novack, Taxation Without Representation, FORBES, Oct. 1, 1990, at 220 (discussing minor adjustments in estate taxation of foreigners who invest in United States).

72. See, e.g., COOPER, supra note 2, at 12-63; see also infra part VI.A.

73. See Bernheim, supra note 2 , at 135 . Of course, the normative propriety of charitable contributions is rather different from that of inter vivos transfers, as I discuss later. See infra part V.C.3.

74. In formal terms, this would mean that agents had marginal utility functions such that 
of this story would involve nonaltruistic, linked gifts: situations where members of an older, wealthier generation transmit wealth downstream with the explicit or implicit understanding that they can receive help later, if needed. ${ }^{75}$ If the benefits generated by the combined income and estate tax savings are greater than the transaction costs of making these arrangements, standard microeconomic theory predicts that the deals will transpire. Obviously, these matters are difficult to pin down, but Bernheim at least concludes that the net revenue effect of the estate tax is apt to be small and possibly even negative. ${ }^{76}$ While this strong conclusion of a negative revenue effect seems improbable, the estate tax clearly is not a significant source of revenue, as even its most thoughtful advocates acknowledge." Further, Bernheim's story is a partial-equilibrium one, in the sense that he does not consider the impact of diminished work or savings efforts under the estate tax. In this regard it is likely that Bernheim's analysis strongly overestimates the revenue gain from the estate tax; diminished productivity unequivocally costs the government tax revenue.

$$
M U_{1}^{\prime}(C(w-u))>M U_{i}^{:}(C(w))
$$

but

$$
M U_{1}^{1}(C(w-i t))<M U_{1}^{2}(C(w-e l)) .
$$

where $M U\left(^{*}\right)$ is the individual's marginal utulty function; the subsenpt I represents Agent I's utulity (Agent 1 is the potential donor): the superseript $I$ or 2 represents the person consumung (Agent 2 is the potential beneficiary); $C\left({ }^{*}\right)$ is the consumption function: " is wealth and $\|$ and $e t$ are the income and estate taxes, respectively. Thus, equation (1) mantains that Agent 1 prefers her oun uility of consumption at the margin to that Agent 2. even where her wealth-but not the benefictary's-is eeduced by the income tax. (Think of it as the added income tax owed by virtue of the wealthier donor holding the wealth). Equation (2) maintains that the same agent prefers other consumption more than her oun when the other's consumable wealth is reduced by the estate tax. In such a case. Agent I will transfer enough wealth to Agent 2 to equate the marginal uttlitics. saving both income and estate taxes in the process. This is Bernheim's basic story. See Bernheım, supra note 2, at 135-37

75. See, e.g., Laurence J. Kotlikoff \& Avia Spivak. The Famull as an Incompletr Annuttes Market. 89 J. POL. ECON. 372, 372 (1981)

76. Even without large rate disparities-Bernhesm almost cenanny exaggerates the extent to which inter vivos gift recipients are or remain in the $15 \%$ bracket-the idea that estate-tax-motuvated transactions lose income tax revenue for the government is stull plausible. The guft and estate tax regime affects the choice of investment vehicles just as $\|$ does the tuming of gifts. Downstream gifts are apt to be placed in less income-generating assets. A paradigm case is insuranec. For example. much evidence indicates that the estate tax is a major part of the pitch employed by insurance agents to wealthy taxpayers. See Karen Slater Damato. Insurance Agents Find Profil in Estale-Tax Fear. WalL. ST J. May 21,1993 , at C1. An insurance trust is, indeed, the ultimate tax-sheltered vehicle-forever immune from both income and estate taxes when properly designed. See 1.R.C. $\$ 20.42$ (1994) (excluding income tax proceeds from gross estate unless deceased retained "incidents of ownershı"). id. $\$ 101$ (generally excluding life insurance proceeds). Similar effects obtan from chantable gifts and the complex "split interest" trusts that are a staple of sophisticated estate tax planning. For funher discussion and some planning techniques. see SCHOLES \& WOLFSON, supra note 55. at 575-98 (describing planning techniques). Both insurance and charitable strategies are widely advertised and promoted in vehucles targeted to wealthy audiences. There is also something to the thought that taxpayers who are estate-taxwise are also income-tax-wise. Advisors who are consulted for estate planning purposes are apt to recommend income-tax-minimizing strategies as well. See Bernherm, supro note 2, at 132-35

77. See Duff, supra note 2, at 7: Graetz. supra notc 2. at 269-70. But of. Ascher. supra note 2. at 72. 
Whatever one thinks of the Bernheim analysis, two points are important. First, the fact that the estate tax does not raise significant amounts of revenue is an aspect of our actual practices that we ought to take seriously. The relevance of this fact derives not merely from the estate tax's failure to raise more revenue, but also from the deeper set of facts concerning why the tax is such a limited revenue raiser, and why there is so little popular or political will to extend it. This situation informs the interpretive case against the estate tax. Second, the estate tax's "loopholes," exceptions, and exclusions work alongside, and must be considered together with, parallel "loopholes" in the general income tax. Regardless of whether Bernheim's strong hypothesis of net revenue loss is ultimately sustainable, any attempt to shut down the estate tax's gaps without simultaneously considering income tax gaps may generate counterproductive results. We must think more comprehensively about all of our various taxes, as I attempt to do in Part V.

\section{Capital Stock Effects}

Another part of the consequential aspects of estate taxation concerns the tax's effects on the capital stock. By "capital stock," I am referring to the aggregate level of social savings, measured in various ways. ${ }^{78} \mathrm{I}$ want to make clear from the outset, consistent with a liberal egalitarian focus, that I am not arguing, as others might, for capital formation as the "trump"79-that is, the decisive concern that tips the balance of arguments against estate taxation. Rather, I discuss capital formation for two distinct reasons. First, I believe that capital formation is relevant, even if not decisive, for all but the most purely rights-oriented liberal egalitarians. Capital formation has important effects on intra- as well as inter-generational well-being-a point that some liberal egalitarians have often missed or misunderstood. Rawls' conditional acceptance of inheritance suggests that he is aware of advantageous social effects from inter-generational savings, ${ }^{80}$ for example, and he elsewhere directly acknowledges the importance of capital for a liberal state. Perhaps most important, citizens in a political liberal state may reasonably like capital and what it provides. They might objectively decide that the accumulation of private capital is worth its costs, especially if, as I shall argue below, an appropriate tax policy can contain these costs by constraining the nominally private possession of wealth. Second, the reasons why estate taxation affects

78. See generally Aaron \& Munnell, supra note 6 (discussing various means of measuring aggregate savings level currently in use); B. Douglas Bernheim \& John Karl Scholz, Private Saving and Public Policy, in 7 TAX Policy AND The EConomy 73 (James M. Poterba ed., 1993) (same).

79. The phrase derives from Graetz, supra note 2, at 278, who is both critical and skeptical of capital formation arguments.

80. THEORY OF JUSTICE, supra note 19, at 287-93, 298-301; Justice as Fairness, supra note 29, at 129-31. 
the capital stock are relevant to the liberal egalitarian case, even if we are not concerned with capital formation per se. The behavioral responses suggested by back-ended wealth taxation-inter vivos giving and increased leisure and consumption-cast doubt on even the rights-oriented liberal egalitarian's case for estate taxation.

The general subject of capital formation and its relationship to estate taxation is controversial. While commentators have long noted the possibility that a wealth transfer tax might adversely affect the capital stock, advocates of wealth transfer taxation have responded with two sometimes intermingled lines of attack. One is the categorical claim that the aggregate capital stock does not matter, or alternatively that the stock is ample at any particular moment in time. A second line of attack features skepticism about the empirical effects of the tax on actual private decisions. ${ }^{81}$

The first response raises complex issues of inter-generational justice. Economists since Keynes have noted that it is possible to oversave, ${ }^{x_{2}}$ and political and moral philosophers similarly remain divided over questions of optimal savings policy. ${ }^{83}$ Moreover, it is often difficult to determine where a society stands relative to its optimal savings rate or its optimal capital stock. ${ }^{84}$ Still, there does seem to be a present consensus that the United States' capital stock and savings rates are both too low at the moment. ${ }^{\text {"s }}$ Perhaps more important for the present project, both our current practices and contemporary tax theory have been tilting toward a consumption tax model, in part because of the consumption tax's greater inducement toward saving. If liberal society simply wants more capital for reasonable political reasons, then parts of our tax system may be operating at direct cross-purposes. We must figure out whether and why we want more savings and analyze all aspects of public finance more consistently on this score. ${ }^{86}$

81. See, e.g., Ascher, supra note 2, at 102-06; Graetz, supra note 2, at 279-83. Haslett. supra note 3 , at $145-48$.

82. Keynes himself noted earlier economists who believed that oversaving was possible JoH MAYNARD KeYNes. THE GENERAL THEORY OF EMPLOYMENT. INTEREST. AND MOYEY 358-71 (1936). see also Graetz, supra note 2, at 279 (questioning need for more savings): The US Economs Max: Dominate for Years, WALL ST. J.. Jan. 10. 1994, at AI ("Japan's expenence suggesis a country can invest too much.").

83. See, e.g., THEORY OF JUSTICE, supra note 19, at 286-90; Amartya Sen. On Optumesing the Rate of Saving. 71 ECON. J. 479 (1961).

84. For classic discussions of the role of savings and optumal savings rates in furthenng growth. sec generally WILLIAM H. BRANSON, MACROECONOMIC THEORY AND POLICY 561-640 (3d ed 1989). Edmund S. Phelps. Second Essay on the Golden Rule of Accumulation. 55 AM. EcoN REv 793 (1965). Edmund S. Phelps, The New View of Invesiment: A Neoclassical Analysis, 76 QJ Ecov 5.48 (1962). Sen, supra note 83; Robert M. Solow, A Coniribution to the Theorv of Economic Growih, 70 QJ Ecov 65 (1956). Professor Graetz, writing in 1983, noted the debates. Graetz. supro note 2. at 278-83

85. See, e.g. Benjamin M. Friedman, Day of Reckoning The Consequences of AMERICAS ECONOMIC POLICY (1989); STRENGTHENING OF AM. COMM'N. FIRST REPORT (1992). Haroid T Gross \& Bernard L. Weinstein. The Past and Future of U.S. Prvate Saving. Challevge. July-Aug 1992. at 42. But cf. Richard Ruggles, Accounting for Saving and Captral Formation in the Umited States. 1947-199J. J. ECON PERSP., Spring 1993, at 3 (criticizing methods of accounung for savings and noung that capital formation is more important than savings incentives).

86. To compare apples with apples, it may be sensible to vew policies that change the estate tax 
There are other puzzling aspects about the how-much-savings question. Whatever one thinks of the complicated social question of the optimal savings rates and capital stock, more savings would help reduce the cost of capital and increase productivity, ultimately resulting in higher wages ${ }^{87}$ Since wages are the key element of the tax base, and indeed the only element in the increasingly important payroll tax system, ${ }^{88}$ capital enhancements should increase the general tax base. More important, capital stock may improve intragenerational opportunities. There is this enduring paradox in tax policy: On the typical assumption that the elasticity of substitution between capital and labor is less than unity, increased capital stock decreases the return of capital and increases the relative share of labor. ${ }^{89}$ The normative propriety of savings is ambiguous. Capital itself may help all of society, perhaps especially the working classes, even though it is apt to be concentrated in the hands of the wealthy. At this point, the distinction between the use and possession of wealth becomes relevant, even decisive. Liberal society ought to look for a way to facilitate the private possession while minimizing the risk of the distortionary

in conjunction with other policies that keep the capital stock constant. This point is central in Joseph E. Stiglitz, Notes on Estate Taxes, Redistribution, and the Concept of Balanced Growth Path Incidence, 86 J. POL. ECON. S137 (1978). In the case of increasing the estate tax, assuming that this does entail a reduction in the capital stock, this means supplementing the policy with other inducements to savings, such as tax benefits or a reduction in social security. Id. at $\$ 139$. Studies that simply show a large net benefit from eliminating the estate tax without making corresponding changes are doing little more than: (a) predicting the behavioral responses to repeal of the estate tax (i.e., that savings will increase), and (b) reflecting relatively conventional economic theory as to the effects of more savings. See, e.g., Richard Wagner, Federal Transfer Taxation: A Study in Social Cost, in INSTITUTE FOR RESEARCH ON THE ECONOMICS OF TAXATION, FISCAL ISSUES 8, at 17-19 (1993) (arguing that capital stock would now be $\$ 398.6$ billion higher if estate tax had been repealed in 1970, and that repeal in 1993 will increase capital stock by $\$ 638.9$ billion and GDP by $\$ 79.2$ billion by the year 2000 ). If we assume instead that socicty has determined an optimal savings level, and ask how this is to be maintained, a more precise answer to the differential costs of the estate tax can emerge.

87. There is an important caveat about these effects in an open economy, however, where capital can flow into other countries. In such a case, the productivity enhancements may take place abroad. See Joel Slemrod, Effect of Taxation with International Capital Mobility, in UNEASY COMPROMISE: PROBlems of A HYBRID INCOME-CONSUMPTION TAX 115 (Henry J. Aaron et al. eds., 1988) (hereinafter UNEASY COMPROMISE]; see also Frank Levy \& Richard J. Murname, U.S. Earnings Levels and Earnings Inequality: A Review of Recent Trends and Proposed Explanations, $30 \mathrm{~J}$. ECON. LITERATURE 1333, 1372 (1992) (explaining that one effect of trade deficit is to reduce jobs in manufacturing). Of course, there is an interesting but seldom-asked normative question of whether we should be concerned solcly with American prosperity. In an open economy, greater capital will help wage earners throughout the world.

88. On the increasing importance of social security and other payroll taxes, see generally McCaffery, Cognitive Theory, supra note 10.

89. As Stiglitz explains,

The reason that the estate tax may not increase the equality of income is the following: the estate tax may reduce savings; the reduction in savings and capital accumulation will, in the long run, lead to a lower capital labor ratio; and the lower capital labor ratio will, if the elasticity of substitution between capital and labor is less than unity, lead to an increase in the share of capital.

Stiglitz, supra note 86, at S138 (footnote omitted); see also Boskin, supra note 17, at 64; Lawrence H. Summers, Capital Taxation and Accumulation in a Life Cycle Growth Model, 71 AM. ECON. REV. 533, 542 (1981). But cf. A.B. Atkinson \& A. Sandmo, Welfare Implications of the Taxation of Savings, 90 ECON. J. 529, 533, 542 (1980) (noting numerous complexities and empirical issues involved in estimating welfare effects of taxing savings); Martin Feldstein, The Welfare Cost of Capital Income Taxation, 86 J. POL. ECON. S29, S39-42, S49-50 (1978) (same). 
private use of wealth. This is exactly what a progressive consumption-withoutestate tax aims to do, as I shall argue more fully in Part V.

I address the skeptical component of the second criticism, that the estate tax is unlikely to affect savings in any event, in discussing issues of empirical uncertainty later. ${ }^{90}$ As an aside, it is important to note a common mistake in the tax policy literature. The fact that the wealth transfer tax system has a low revenue yield does not by itself mean that its effects on behavior or the capital stock are also small. We need to explore why the revenue yield is so low. If the low yield results from behavioral adaption to the tax regime, we would have both large behavioral effects and scant revenue-just as we might have, for example, if we drastically raised the cigarette tax. ${ }^{91}$ In any event, the estate tax might affect the capital stock for one of two different reasons. One is the behavioral effect on the consumption-savings and work-leisure decisions of the donor class, and on the timing and extent of inter vivos gifts. If, as I argue in Part IV, these induced effects are themselves illiberal, then the capital loss may be merely an insult added to the injury of inequality. The second effect comes from the different employments of capital made by the parties who receive the donor's wealth-that is, the government and private donees. If these recipients are less likely to save, capital will be lost, even without donor-level behavioral effects.

The question of these two empirical effects depends, in turn, on our understanding of why people save and, relatedly, why they make gifts. A brief foray into intellectual history reveals that ideas about wealth taxation have always been linked to theories of savings. Although both Adam Smith and David Ricardo opposed any form of wealth transfer tax, specifically on the grounds that such taxes impair capital and therefore hur social wealth." most early discussions of such taxes in the literature, including Jeremy Bentham's and John Stuart Mill's, were characterized by a naive sense of the motives for saving. Bentham, Mill, and others assumed that bequests were made out of fortuitous leftovers, so that levying the estate tax could not cause adverse incentive effects at either generational level. Bentham and Mill accordingly

90. See infra part VI.B.

91. See Go On, Tax the Real Killer. ECONOMIST, Nov. 27, 1993, at 28. 29 (reportung Senator Moynihan's proposal to tax handgun ammunition at rates ranging from 50\% to $10.000 \%$, in attempt to raise revenue while simultaneously taxing the most dangerous bullets out of existence). Scoll $R$. Schmedel, Tax Report, WALL ST. J., Feb. 17, 1993, at A I (noting study by Counctl of State Governments that found sin taxes no longer good sounces of revenue): Rick Wartzman. Clinton's Proposal for "Sin Taxes" May Stumble by Turning Too Many Americans into Saints. WALL ST. J.. Apr 14. 1993, at A16 (discussing tobacco and alcohol taxes and trade-off between behavior modification and revenue production goals); see also Edward J. McCaffery. Taxation and the Famul:: A Fresh Look at Behavioral Gender Biases in the Code, 40 UCLA L. REv. 983. 1044 n.229 (1993) (noung that former President Gorbachev of Soviet Union lost money by overtaxing alcohol on moralistic grounds)

92. 2 ADAM SMITH, THE WEALTH OF NATIONS 391-92 (Edwin Cannan ed . 1976) (1776). David RICARdo, The PRINCIPLES OF POLITICAL ECONOMY AND TAXATION 94-97 (Emesi Rhys ed. Everyman's Library 1911) (1817); see also Graetz, supra note 2, at 282-83 (citıng M1AX WEST. THE INHERITANCE TAX (2d ed. 1908)). 
viewed death taxes as the best possible tax.

This early sense of motives for saving received an intellectual boost from the speculations of John Maynard Keynes and, later, from the work of Nobel laureate Franco Modigliani. Keynes hypothecated a fixed savings-toconsumption ratio: a rule of thumb that an individual consumer adopted and then, rather inexplicably, followed for the rest of her life. Modigliani and others advanced and developed this speculation into the "life-cycle" theory of saving. Under this theory, individuals are concerned only with their own generation's consumption. They save early in their lives, during periods of peak earnings, solely to achieve a smooth consumption path throughout their lifetimes; the life-cycle (or "permanent income" ${ }^{\text {"93 }}$ ) theory holds that individuals annuitize their private wealth.

Life-cycle theory persisted as the dominant, indeed nearly exclusive, model of savings until the early 1980's, and it continues to inform discussions of the estate tax in the tax policy literature. ${ }^{94}$ Beginning in the late 1970 's, however, further research into savings behavior, led by Laurence Kotlikoff and Lawrence Summers, began to question the life-cycle hypothesis. Kotlikoff and Summers found that not all of the data fit an exclusively life-cycle model: Individuals were not completely annuitizing their wealth, even where they could, and many who did save passed significant sums inter-generationally. ${ }^{95}$ The elderly wealthy often continued to save, not dissave as the life cycle model had predicted. The authors concluded that $50 \%$ to $80 \%$ of all national wealth represented inter-generational savings. Although the debate over the motives and determinants of savings is continuing, even neutral observers concede that a high proportion-at least one-fourth-of national wealth is held as intergenerational, or bequest, savings. ${ }^{96}$

93. See Milton Friedman, A THEORY of THE CONSUMPTION Function 20-31 (1957) (explaining permanent income hypothesis); see also Franco Modigliani \& Richard Brumberg, Utility Analysis and the Consumption Function: An Interpretation of Cross-Section Data, in POST-KEYNESIAN ECONOMICS 388, 388-436 (Kenneth K. Kurihara ed., 1954) (explaining life-cycle hypothesis).

94. Useful background on theories of savings can be found in THOMAS A. BARTHOLD \& TAKATOSHI ITO, BEQUEST TAXES AND ACCUMULATION OF HOUSEHOLd WEALTH: U.S.-JAPAN COMPARISON 1-3, 41-44 (National Bureau of Economic Research Working Paper No. 3692, 1991); LAURENCE J. KotlikofF, What Determines Savings? 1-35 (1989) [hereinafter KotLikOFF, What Determines SAVINGS?]; Aaron \& Munnell, supra note 6, at 130-32; Michael D. Hurd, Savings of the Elderly and Desired Bequests, 77 AM. ECON. REV. 298 (1987); Laurence J. Kotlikoff, Intergenerational Transfers and Savings, 2 J. ECON. PERSP. 41 (1988) [hereinafter Kotlikoff, Intergenerational Transfers]; Paul L. Menchik \& Martin David, Income Distribution, Lifetime Savings, and Bequests, 73 AM. ECON. REV. 672 (1983).

95. See, e.g., KotLikoff, What Determines SAVings?, supra note 94, at 41; Laurence J. Kotlikoff \& Lawrence H. Summers, The Role of Intergenerational Transfers in Aggregate Capital Accumulation, 89 J. POL. ECON. 706, 707 (1981); see also Hersh M. Shefrin \& Richard H. Thaler, The Behavioral Life Cycle Hypothesis, 26 ECON. INQUIRY 609 (1988) (suggesting that data require modification of life-cycle theory).

96. See, e.g., Aaron \& Munnell, supra note 6, at 132 (finding that inherited wealth accounts for at least $30 \%$ of national net worth); BARTHOLD \& ITO, supra note 94 , at 44 (finding that $25-40 \%$ of capital stock in U.S. and Japan represents inter-gencrational transfer). But cf. Hurd, supra note 94, at 298, 306-07 (questioning existence of bequest motive, although finding significant midlife inter vivos 
This brief survey indicates that actual economic behavior is more rich and complex than handy a priori explanations would suggest. There are undoubtedly many diverse motives for saving, both across people and within individuals. The important point for wealth taxation theory is that various means of taxing wealth can have very different effects, depending on why people save. For example, estate taxation poses no severe disincentives under a life-cycle savings model, but disincentives can be severe under a bequest savings one. ${ }^{97}$ Any change in our understanding of why people save should thus change the way we think about the estate tax. In 1916, it might have appeared that the estate tax could have given us our cake while allowing us to eat it, too: We could have served the liberal egalitarian equal-opportunity ideal and raised revenue, all with no significant adverse effects on behavior or capital stock. The life-cycle model lent intellectual support to this neat package of virtues (and on this account alone ought to have raised some skepticism). The new and emerging theories on why people save have destroyed the happy convergence.

A question related to why people save is why they make gifts or bequests. The early, Mill-Bentham view, continued under the life-cycle hypothesis, was that bequests were mere "accidents" owing to the uncertain timing of death and the absence of perfect annuity markets. A second view, typically invoked by Gary Becker and others in the neoclassical economic tradition, is that bequests provide direct utility to the donor, because the utility of related parties (i.c., donees) enters into one's own utility function; this is an altruistic

\footnotetext{
transfers). Hurd also notes the absence of the very wealthy from the data, due to their reluetance to be interviewed. Id. at 307.

97. "Ricardian equivalence" might seem to dictate that estate taxation would hase no net effect on saving. Ricardian equivalence is the theory that the govemment's choice of debt or tax Hancung is irrelevant. Altruistically linked generations simply save more if the governinent chooses debi hnaning to make up for the rationally anticipated future taxes required to pay down the debt Ser senerull, Robent J. Barro, Are Government Bonds Net Wealth? 82 J. POL. Eco. 1095 (1974) (articulating theory that debt/tax ratio is irrelevant). Although the theory may seem implausible on its (ace, aggregate matrodata tend to support its general validity. See. e.g.. John J. Seater. Ricardion Equmalemer. 31 J Ecov LITERATURE 142 (1993) (finding some cconomeine support for Ricardian equivalence), of B Duuglas Bernheim, Ricardian Equivalence: An Evaluaton of Theors and Evidnce. In MAckotcovowits ANNUAL 263-9] (Stanley Fischer ed., 1987) (finding some econometnc suppon for Rucardian equivalence, but concluding that it is unlikely). There are. however. some important differences in the case of estate taxation. First, the Ricardian effect may in fact be largely due to imperfect or rish-averse life-cycle saving; individuals may anticipate or fear the increased tax burdens coming in their oun lifetimes. Second. since the estate tax does not mise enough revenue to have any meaningful effect on general tax rates, there is no meaningful income effect at work, present disposable incone would not increase from the repeal of estate taxation. as it would from a choice of large-scale debi hinancing aver current income taxation. (Another way to see this idea is to understand Ritardian equivalence as a constant consumption hypothesis: When debt substututes for taxition. the rational consumer"s consumption is unaffected, so she simply saves the increased disposable income from the thotee of financing vehicle. If, however, consumption remains unaffected b) the choice of estate tax. so 4 ill savings, and equivalence will not hold.) Finally. It seems intuiturely implausible thal Ricardian equivalence would govern the behavior of the very neh taxpayers under the shadous of the estate tax Indeed, if equivalence does hold at this level, it would seem to be a feature of consumption satiation. as the prior point suggests.
} 
explanation. ${ }^{98}$ Attempts to fit the simple, apparently selfless act of gift-giving into a narrow, self-interested theory have had predictable consequences. The latest, emergent theory, borrowing from game theoretic ideas, is that gifts are strategic; that is, they are made to further one's own, purely self-regarding interests. There are two strands to this new view, not always properly differentiated in the literature. One holds that a donor uses the allure of bequests and the threat of their withholding to control the behavior of others- to get children to be more attentive, for example. ${ }^{99}$ A second type of strategic motive is more subtle: Family and other interrelated groups form an informal annuity or insurance pool, to which donors make contributions with the at least implicit understanding that the donees will care for them if the donor's resources run out.

Like the life-cycle versus bequest-savings debate, these various motives are not incompatible. All no doubt exist, not only across society but also within individual donors. Once again, sorting through these motives may have decisive consequences for predicting and evaluating the likely effects of a changed tax regime. If, for example, family members use gifts to create intrafamilial annuities, encouraging such gifts may not do much even to break up concentrations of wealth; Bernheim's speculation about income tax savings would also become more compelling. At a minimum, our more sophisticated knowledge of why people save and make gifts should lead us to rethink basic paradigms of estate taxation.

In any event, capital will likely decrease due to behavioral effects on work and consumption decisions at the donor level; I discuss this issue more fully in Part IV, but it is initially hard to believe that high tax rates do not have disincentive effects, at least once we move beyond the life-cycle/fortuitous leftover view of large bequests. There is still the further question of what the government or the induced donees might do with the revenues generated. As it turns out, this area is another one in which primitive views, again harking back to Bentham and Mill, have impeded sophisticated normative analysis. The early view was that as long as governments ran deficits, a tax on capital could have no negative impact on total capital stock. As Mill explained, "the produce of the tax, thus applied, still remains capital, and is merely transferred from the tax-payer to the fundholder." 100

98. See GARY S. BECKER, A TREATISE ON THE FAMILY 277-306 (enlarged ed. 1991) (hereinafter BECKER, TREATISE ON THE FAMILY]; Gary S. Becker, Altruism in the Family and Selfishness in the Market Place, 48 ECONOMICA 1, 1-10 (1981); Gary S. Becker, A Theory of Social Interactions, $82 \mathrm{~J}$. POL. ECON. 1063, 1074-83 (1974).

99. See generally B. Douglas Bernheim et al., The Strategic Bequest Motive, 93 J. PoL. ECoN. 1045 (1985) (discussing gifts as means of compensation for services rendered); Donald Cox, Motives for Private Income Transfers, 95 J. POL. ECON. 508 (1987) (comparing altruistic and exchange models of transfers and finding evidence supports latter).

100. MILL, supra note 48, at 822-24; see also Ascher, supra note 2, at 110-11 (quoting Mill with approval); Graetz, supra note 2, at 282-83 (citing MAX WEST, THE INHERITANCE TAX 209 (2d ed. 1908), and describing West's comments on Mill). 
This theory, however, is surely too simplistic. ${ }^{101}$ A capital tax undoubtedly would affect individual savings incentives. No one could plausibly argue that a confiscatory income tax would have no effect on capital so long as its proceeds were used to pay down the national deficit. Moreover, it is far from clear that the government would use all of the capital tax to reduce its deficit. Indeed, it is rather unclear what such specific allocations or "earmarkings" even mean. ${ }^{102}$ Modern public choice scholarship has argued forcefully about the effects on total government spending of new revenue sources. ${ }^{103}$ It seems likely that the government, or the beneficiaries of the government's redistributive program, will be less intensive savers than the very wealthy whom the tax directly impacts. The economist Joseph Stiglitz relied exclusively on this effect in surmising that the gift and estate tax regime is costly in terms of the capital stock; he posits that the tax effects a transfer from those with higher propensities to save to those with higher propensities to consume. ${ }^{104}$ Adam Smith made essentially the same point more than two hundred years earlier. ${ }^{105}$ If this Stiglitz-Smith conjecture is true, then total national wealth decreases under any estate tax, even if the elasticity of capital accumulation to the estate tax rate is zero. If the capital stock has elements of a public good, the good may be enhanced by the nominally private ownership of capital.

One might object that a negative effect on capital will obtain under any effort to tax wealth or to redistribute resources generally, so that the capital stock theme is simply an argument against "progressivity" or even against distributive justice itself. Any redistributive attempt will diminish the incentives of the most wealthy-without question a critically important class

101. If restated as a variant of the Ricardian hypothesss, the tdea is harder to refute An extreme version of the Ricardian hypothesis maintains that savings is completely independent of the means and extent of government financing, thus mooting any question of the effect of taxation on capital But there appears to be little support for such an extreme view. See Bernheim. supra note 97 (finding reason to support Ricardian hypothesis in the aggregate, despite questuons on individual level). of Scalcr, supra note 97 (finding some econometric support for Ricardian equivalence). I believe that there is some reawo to be especially skeptical of the Ricardian hypothesis as applied to the estate tax Ser supra note 97 This question calls for close empirical analysis. not easy a priort speculation

102. The technique of earmarking has been studied in connection with state-run lottenes in Amenta. where it is often found that direct use of funds for a specified purpose is at least partally undermined by indirect cuts in general appropriations toward the same end-the so-ealled "front door/bach door"

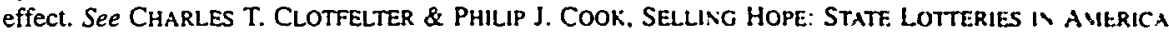
227-28 (1989) ("II]t is unlikely that lottery revenues have much effeet on the pattern of expenditures") This effect is related to the so-called "flypaper" effect. under which lump sum grants to certain governmental agencies "stick" to their first recipient rather than being passed on to the ultumate. intended beneficiaries. See Wallace E. Oates. On The Narure and Measurement of Fiscal Illusion A Surver. in TAXATION AND FisCal FEderalism 65, 77-78 (Geoffrey Brennan el al eds. 1988)

103. See, e.g., DENNIS C. MUELL.ER. PUBLIC CHOICE II 268-7I (1989) (ciling numerous sources and discussing "Leviathan" theory of government).

104. See Stiglitz, supra note 86 , at S138.

105. See 2 SMITH, supra note 92, at 391 (pointing out that wealth taxes shift capital from productuve private to unproductive public sector: "They are all more or less unthrifls taxes that increase the revenue of the sovereign, which seldom maintains any but unproductive labourers; at the expence of the capital of the people, which maintains none but productive."). 
when it comes to capital accumulation-to work or save. All such redistributions will also involve moving wealth in the direction of those with lesser propensities to save. Therefore, the argument runs, a concern over capital proves too much and is doomed to be "conservative" or illiberal.

I do not accept this argument. It reflects a failure to think through the normative distinction between the possession and use of wealth. If we progressively tax the use of wealth, we will not necessarily chill its private accumulation. ${ }^{106}$ Nor will we necessarily move capital into the hands of those with greater propensities to consume. As we shall see later, a progressive consumption tax is a way of protecting a "frugal capitalist class" while penalizing only the "self-indulgent aristocracy." 107 Indeed, taxing the use of wealth changes the very meaning and dangers of private possession. ${ }^{108}$ Under a progressive consumption tax, Mr. Perot would have had to pay vast sums of money in taxes on his presidential bid; under our current income-plus-estate tax, the campaign saved the Perot family some $\$ 33$ million in estate taxes. ${ }^{109}$ Compared to the current tax system, a progressive consumption-without-estate tax will provide society with a better balance of what truly matters. I return to these issues in Part V.

\section{THE (Liberal) FAILURES OF THE EstATE TAX}

Part III set out the details of the current estate tax and showed that they might not be sensible in several immediate ways. The law is very complicated and porous. It raises little revenue and may even cost the government money. It almost certainly negatively affects the capital stock, both by inducing important potential savers to save less and by putting money in the hands of more spend-happy parties. Yet these suggestions, however troubling, do not seriously undermine the strongest liberal case for wealth transfer taxation. Rawls, after all, specifically advocated such taxes "not to raise revenue," but

106. See infra part V.C.2.

107. These terms are derived from Rawls. See THEORY OF JUSTICE, supra note 19, at 298-99 (arguing that society should allow wealth accumulation "only in special circumstances, including the frugality of the capitalist class as opposed to the self-indulgence of the aristocracy"); see also infra notc 232 and accompanying text.

108. See infra part V:C.3.

109. This figure assumes a $\$ 60$ million campaign cost and a $55 \%$ estate tax rate; there is no reason to adjust the figure to take into account the time value of money because the $\$ 60$ million, and hence the tax on it, would grow at the social discount rate. See George Skelton, Capitol Journal: Deep Pockets and a New Day for Voters, L.A. TIMES, Oct. 10, 1994, at A3.

Interestingly, as this Article was going to print, the Perot phenomenon was playing itself out, on a slightly smaller scale, in the California Senate race. Republican challenger Michael Huffington, with a net worth of about $\$ 70$ million or more, was said to be spending $\$ 20$ million or more of his own money challenging the incumbent Democrat Dianne Feinstein, herself a wealthy woman. Sce $i d$.; Dan Balz, High Rolling in California: Anti-Government Challenger Pours Millions into Senate Race. WASH. PosT, Oct. 6, 1994, at Al; Kathy Kiely, Ex-Houstonian Pouring Gold into Them Thar Hills: Huffington Challenges Feinstein in California, Hous. POST, Oct. 6, 1994, at A1. 
to correct for the essentially political problems of wealth concentration. ${ }^{110}$ Further, even if our laws fail to live up fully to their ideals or are a bit senseless in practice, where is the harm? What is there to suggest either that the current regime is bad, or that the appropriate response to the law's actual, practical failures is not to strengthen it, as the calls for confiscatory wealth transfer taxation explicitly seek to do?

This Part shows that the current estate tax is misguided on purely liberal grounds-the first argument against estate taxation from Part II-and begins pressing the second argument, namely that any stronger or confiscatory alternative is likewise ill advised. This Part moves into a dynamic or behavioral focus, looking at the underlying, individual psychic reasons why the effects of the prior Part obtain. Section A examines two critical sets of behavioral incentives, involving inter livos giving and work-leisure and consumption-savings decisions, and Section B discusses distributive consequences generally. The central theme of this Part is that any scheme of wealth transfer taxation encourages an earlier-in-life transmission of wealth and/or induces increased consumption and diminished work and savings by the wealthy, and that these effects can be decidedly illiberal.

\section{A. Behavioral Incentives}

The conclusion that taxes affect behavior is typically assumed in the general case of income taxes." It should not surprise us that the very wealthy, who are among the most sophisticated and elastic taxpayers, react strongly to the gift and estate tax laws. The evidence is overwhelming that they do. The wealthy spend a good deal of legal and other resources on avoiding the estate tax or mitigating its effects. An informal estimate by a pair of prominent public economists is that the private expenditure on estate tax advice may amount to a sizable percentage of revenue generated." Seminars on developments in the estate tax are extremely common, and a number of professional publications are devoted exclusively or significantly to the subject of estate tax avoidance. Even the popular press often writes about techniques for minimizing or avoiding estate taxes. There is documented evidence that estate tax changes have led, directly and quickly. to changes in the palterns of interspousal transfers. ${ }^{113}$ There is also the somewhat curious fact of the high and increasing amounts of gift taxes paid-evidence of complex, savvy gift

110. THEORY OF JUSTICE, supra note 19, al 277

111. But cf. Joel Slemrod, Do Taxes Matter' Lessons from the 1950's. 32 AV Ecov REv 250 . 251-53 (1992) (noting that behavioral reactions to large tax changes in 1981 and 1986 faled to match extent of predictions, but indicating that difficult-lo-detect responses might explan some vanance) See generally DO TAXES MATTER? (Joel Slemrod ed., 1990) (examıning multuplieity of tax-reform effects)

112. Aaron \& Munnell, supra note 6. at 138.

113. Bernheim, supra note 2, at 121-24. 
and estate tax planning. Any lawyer with experience planning estates for moderately to very wealthy families knows that such clients do, indeed, take advantage of the various means of making gifts to get out of the shadows of the estate tax.

Such tax avoidance efforts hold significance for the liberal egalitarian. This Section examines two such sets of behavioral effects that are decidedly illiberal: (1) inter vivos gifts, and (2) consumption-savings and work-leisure decisions.

\section{Inter Vivos Giving}

The gift and estate tax system encourages frequent, early, and large giving among the very wealthy for three primary reasons. First, the annual exclusion has an automatic use-it-or-lose-it feature that induces wealthy individuals to take advantage of it every year (and early in the year, at that). The effect can be substantial. At a conservative $6 \%$ rate of return, a child of the Perots, say, who receives $\$ 20,000$ a year from her parents, will amass a personal net worth of over $\$ 735,000$ by the time she turns twenty years old. By the age of forty, her fortune will have grown to well over $\$ 3$ million. ${ }^{114}$ At a more aggressive but hardly ridiculous $10 \%$ rate of return, these nominal values are $\$ 1.1$ and $\$ 8.8$ million, respectively. These numbers double if the Perot child is married and if the Perots feel comfortable bringing their in-law into the wealth transmission process, and the numbers quadruple if the other set of parents (the parents-in-law) are so inclined. Moreover, the receipt of these gifts is free from all income and social security taxation. Married couples who receive $\$ 80,000$ from their two sets of parents on January 1 of each year have as many after tax dollars for the entire year as someone earning approximately $\$ 130,000$ in annual wages. ${ }^{115}$ This earnings level is solidly upper class. Medical and educational expenditures are an entirely separate class of exceptions from the gift tax base that can add significantly to the total wealth transmission. ${ }^{116}$

114. Throughout this Article, the hypothetical examples assume that there is no spending out of principal or income and no taxes on the yield, and the examples do not discount figures to take account of inflation. The first two assumptions are not especially severe; as noted throughout, the current hybrid income-consumption tax allows for numerous ways of avoiding current taxation on the yield to capital. and many trusts are indeed designed to limit spending out of principal or income. (In addition, even if wealth is consumed, the figure gives an accurate sense of the value -of the consumption stream.) While the absence of any inflation adjustment does indeed create a "fiscal illusion" effect, the conservative $6 \%$ figure in fact reflects the long-term return on equity investments above the inflation rate. See ROOER G. IBBotSON \& REX A. SINQUEFIELD, STOCKS, BONDS, BILLS AND INFLATION 81-87 (1989).

115. The $\$ 80,000$ figure results from each of the four parents giving $\$ 10,000$ to each of the two spouses. The $\$ 130,000$ figure is derived using a $31 \%$ federal income tax rate plus a $7.65 \%$ social security payroll tax. Taxes would be higher if state taxes were included or if the employer's share of payroll taxes were imputed to the employee. Note that the funds given by the parents are not necessarily after-tax amounts. For example, the parents could have borrowed against their currently untaxed appreciation to make the gift. I discuss further this type of intra-generational arbitrage between income and consumption in Part V.C.

116. See generally John H. Langbein. The Twentieth-Century Revolution in Family Wealth 
Second, the law encourages early use of the $\$ 1.2$ million unified credit, since not only the gift but all subsequent appreciation of it will be out of the estate. This technique is the distilled essence of the popular estate "freeze" maneuver. ${ }^{17}$ The law even allows these first two inducements, toward frequent use of annual exclusions and early use of the exemption amount, to skip over generations, because the complex generation-skipping tax (GST) has even more generous exceptions. ${ }^{18}$ Thus, a grandmother can make just moderately large gifts to a grandchild, and such gifts will likely be seventy years away from a wealth $\operatorname{tax}$ at the grandchild's level. To put some perspective on this effect, a gift of $\$ 100,000$ will grow to over $\$ 6.6$ million in seventy years at a $6 \%$ rate of return, and to over $\$ 106$ million at a $10 \%$ return. A gift of the full $\$ 1.2$ million, passed tax-free, would grow to just under $\$ 1.3$ billion in seventy years, at a $10 \%$ return. It is possible to set up a irust for a child that remains intact for the grandchildren as well, while skipping any wealth transfer tax at the child's generation. Indeed, it is possible to play this game as long as the rule against perpetuities allows. The complex GST is designed to limit abuse, but it also has its own generous exemption levels, including a basic exemption of $\$ 1$ million per donor ( $\$ 2$ million for a married couple). ${ }^{119}$

Finally, the push toward early gifts is exacerbated by the fact that the gift tax is a tax-exclusive tax-the tax is levied on a base that does not include the gift. Thus, to give $\$ 100,000$ under a $50 \%$ gift tax, a donor must have a combined $\$ 150,000 ; \$ 100,000$ goes to the donee and $\$ 50,000$, or $50 \%$ of the net gift, goes to the government. The estate tax, in contrast, is, like the federal income tax, a tax-inclusive tax-the tax itself is part of the base. To bequeath $\$ 100,000$ under a $50 \%$ estate tax, a donor must have a combined $\$ 200,000$; $\$ 100,000$, or $50 \%$ of the aggregate estate, goes to the government, and the

Transmission, $86 \mathrm{MICH}$. L. REV, 722 (1988) (discussıng prunacy of mudife transfers of wealth to fund human capital accumulation in 20th century).

117. See generally SCHOLES \& WOLFSON, supra note 55, at 584-98 (describing planning lechnques. including paradigmatic estate freezing): Aaron \& Munnell, supra note 6. at $134-37$ (same). Anderson \& Howard, supra note 55 (same); Edward J. McCaffery. The Icemun Cometh Agatn Retum of the Estate Freeze?, 46 TAX NOTES 1327 (1990) Thereinafter McCaffery. Estate Freeze) (describing ucalihy taxpayers' attempts to minimize their gift and estate tax). The unified eredit is not indexed for inflation. explaining part of the effect; fear of losing the exemption may be important here, too See Kathy II Kristof, For Your Heirs" Sake, Put Assets in a Living Trust. L.A. Times. June 13. 1993. at DS (“IMI)any Americans ... have shifted into high gear in an effort to take advantage of current estale planning rules before they're made substantially less generous, tax experts say.").

118. The GST law is set out in I.R.C. $\$ \$ 2601-2663$ (1994). For excmptions, see $\$ 2611$ (b) (listung excluded transfers, including payment of medical and educational expenses). $\$ 2612(\mathrm{c})(1$ ) (detining "direct skip" as taxable transfer under chapter 11 or 12, thereby effectively exemptıng annual exclusion gifts): \$ 2631 (creating \$1 million GST exemption). The "Gallo" amendment, which accompanied the GST in 1986, represents an interesting bit of political history. This amendinent established a transitional rule allowing direct skips of up to $\$ 2$ million per grandchild to be excmpt from the GST for a limited period of time. See Edward J. McCaffery. The Holy Grail of Tax Simplificalion. 1990 Wis L REV 1267. $1285 \mathrm{n} .88$. The fact that there was lobbying pressurc for such a provision indicates the degree of interest in making large bequests.

119. I.R.C. § 2631 . 
residual $\$ 100,000$ is left for the heir. In reality, the gift tax simply has a lower rate structure than the estate tax, although the two systems are nominally unified. This feature creates a further inducement in favor of gifts over bequests. $^{120}$

The incentive toward early and frequent inter vivos gifts among the very wealthy is not merely speculative. Although data on the gifts, bequests, and even consumption patterns of the very wealthy are notoriously difficult to acquire, behavior is undoubtedly sensitive to the tax regime. The law has developed to accommodate early transfers by approving of devices, such as the popular Crummey Trust, ${ }^{121}$ that effectively circumvent the requirement that the annual exclusion be of a present interest. ${ }^{122}$ By immunizing the wealth from an offspring's imprudent consumption choices, such techniques allow the donor to give away wealth without parting with effective control. Such techniques thus serve as ideal vehicles for the type of "strategic" gift discussed above. ${ }^{123}$ Every year, between two-and-a-half and three times as many gift tax as estate tax returns are filed, and these estate tax returns indicate that many decedents have used up some or all of their lifetime credit before death. ${ }^{124}$

120. Cutting in the other direction is the fact that gifts take a carry-over basis, under $\$ 1015$, whereas bequests receive a fully stepped-up basis that eliminates any built-in capital gain for income tax purposes, under $\S 1014$. Id. $\S \S 1014-1015$. Even this apparent problem is rather easily avoided, however, by the careful selection of assets, borrowing against appreciated assets and giving cash, or the skillful use of recapitalization or intrafamily installment sales, and so on. See generally CoOpER, supra note 2 (explaining how estate planning can be used to avoid estate taxes). One easy suggestion to deal with the rate preference is to make the tax on gifts tax-inclusive, like the estate tax. See 2 U.S. DEP'T of TREASURY, TAX REFORM FOR FAIRNESS, SIMPLICITY, AND ECONOMIC GROWTH 377-78 (1984); Donaldson, supra note $\mathrm{I}$, at 553 . Since few people actually pay gift taxes, however, and since gifts are in any event favored under the current system, there is little reason to believe that this adjustment would make a substantial difference.

121. See Joseph M. Dodge, Wills, Trusts, and Estate Planning 629-31 (1988) (discussing Crummey v. Commissioner, 397 F.2d 82 (9th Cir. 1968)).

122. See I.R.C. $\S 2503$ (b) (limiting annual exclusion to present interests in property).

123. See supra note 99 and accompanying text.

124. In 1990, 123,500 gift tax returns were filed, compared to 55,800 estate tax returns. INTERNAL REVENUE SERV., 1991 ANNUAL REPORT 26 tbl. 12 (1992). In 1991, the numbers were 147,700 and 60,800 . Id. at 24 tbl. 11. No gift tax return has to be filed for annual exclusion or medical or educational gifts (except in rare circumstances, such as the splitting of a gift made by one spouse between both spouses), so the gift tax returns indicate significant giving. The IRS makes no systematic study of gift tax returns, however, even where gift taxes are paid. In 1991, 4048 of the 24,767 taxable estate tax returns $(16.3 \%)$ indicated that the decedent had made taxable lifetime gifts; the average lifetime giving was just over $\$ 361,000$. But, once again, the figures rose dramatically with wealth, as Table 3 shows:

\begin{tabular}{||c|c|c|}
\hline Size of Estate & $\begin{array}{c}\% \text { Showing } \\
\text { Taxable } \\
\text { Lifetime Giving }\end{array}$ & $\begin{array}{c}\text { Average } \\
\text { Lifetime } \\
\text { Taxable Giving }\end{array}$ \\
\hline$\$ 5-10$ million & $43.4 \%$ & $\$ 481,155$ \\
\hline$\$ 10-20$ million & $55.8 \%$ & $\$ 910,602$ \\
\hline over \$20 million & $71.7 \%$ & $\$ 2,095,095$ \\
\hline
\end{tabular}

TABLE 3. Patterns of Lifetime Giving Among Taxable Estates, 1991 
Another intriguing piece of data is the significant percentage of the gift and estate tax revenue that the gift tax produces every year. In 1990, taxpayers paid over $\$ 2$ billion in gift taxes. ${ }^{125}$ At an average tax-exclusive rate of, say, $40 \%$, this $\$ 2$ billion tax figure translates into $\$ 5$ billion of net gifts, for a total of $\$ 7$ billion in transferred wealth. What is most striking about these numbers is that a taxpayer cannot even pay a gift tax until she has used up her $\$ 600,000$ lifetime credit. ${ }^{126}$ Thus, taxpayers are making large transfers beyond the substantial gifts allowed by the unified credit and the annual, medical, and educational exclusions. Almost by definition, such transferors are passing on significant sums of wealth in an efficient manner, given the gift and estate tax regime. Bernheim estimates that in 1983 alone, taxpayers transferred inter vivos as much as $\$ 20$ billion (in 1983 dollars)—an amount that roughly equals three-and-a-half times the gift and estate tax revenues, and $\$ 40$ billion in 1993 dollars-because of the estate tax. ${ }^{127}$ These large transfers represent a far cry from the image of bequests as fortuitous leftovers.

There are other data to support the effects. Some evidence, for example, suggests that charitable contributions are sensitive to the estate tax rate. This fact is not at all intuitively obvious or predictable. ${ }^{128}$ Gift and estate taxes

See Johnson, supra note 56, at $91 \mathrm{tbl}$. 1. The table indicates that the ven nealthy estates were actually going well beyond the unified credit amounts. Causality in these matiers is difficult, if not impossible, to make out: one might expect gifts to increase in magnutude and frequency along with wealth. even without wealth transfer taxation. Taxable gifts. however. are clearly much more common and extensive in taxable estates. Nontaxable estates, most of which are nontaxable because of the mantal deduction. have much smaller numbers, as Table 4 illustrates:

\begin{tabular}{|r|c|c|}
\hline Size of Estate & $\begin{array}{c}\text { \% Showing } \\
\text { Taxable } \\
\text { Lifetime Giving }\end{array}$ & $\begin{array}{c}\text { Average } \\
\text { Lifetime } \\
\text { Taxable Giving }\end{array}$ \\
\hline$\$ 5-10$ million & $30 \%$ & $\$ 264.702$ \\
\hline$\$ 10-20$ million & $37 \%$ & $\$ 310.179$ \\
\hline over $\$ 20$ million & $40 \%$ & $\$ 486.167$ \\
\hline
\end{tabular}

TABLE 4. Patterns of Lifetme Giring Among Nontaxable Estates. 1991

Id. These figures differ dramatically from those show'n in Table 3. indicating that those persons who face an imminent estate tax, say following the death of their spouse, are much more likely to make stzable gifts. This behavior is, to some extent, also to be expected. although I believe it reflects some of the incentives toward inter ywos giving generated by the gift and estate tax.

125. INTERNAL REVENUE SERV.. supra note 124, at 15 tbl 1

126. See Rev. Rul. 79-398. 1979-2 C.B. 338. It is necessary to require this result because some donors would prefer to pay a gift rather than an estate tax. due to the former's tax exclusivity

127. Bernheim, supra note 2, at 126-27. I adjusted for inflation by doubling the amounts. $C f$. David Altig \& Steven J. Davis, The Timing of Intergenerational Transfers. Tux Poltcy, and Aggregate Savings. 82 AM. ECON. REV. 1199, 1200-01 (1992) (noting prevalence and magnilude of inter vivos intergenerational transfers): Wolff, supra note 6. at 557 (suggesung that large inter wwos gifts are major factor in wealth inequality).

128. Bernheim, supra note 2, at 131-32. This fact is not necessanly intuture because an individual generally needs a charitable inclination to make a contribution. since she rarely makes money by giving Of course, the tax rate could affect the relative weighing of chartable motuves is the tax goes up. a 
have had a consistently low yield, almost irrespective of the generosity of the exceptions and exclusions, which the government has periodically tightened or loosened through the course of the present century. While some scholars have interpreted this low yield as evidence of the porousness of the legal regime, ${ }^{129}$ an equally plausible inference is that taxpayer behavior is adapting to the gift and estate tax's varying incentives. In fact, every year taxpayers transmit more than one-and-a-half times as much wealth by inter vivos gifts as by bequests, and this disparity does not reflect the hard-to-value, but highly important, transmission of intellectual capital and opportunities. ${ }^{130}$

No doubt, the statistics here could be both more and better, and causality is difficult to establish. I strongly suspect that the estate tax causes much inter vivos activity, although certainly some of this activity takes place for reasons unrelated to tax. But putting aside for now these empirical issues, three conclusions arise from this discussion of the incentives for inter vivos gifts. First, the incentives for tax avoidance can lead to income tax losses that swallow up at least part of the estate tax gain. This is Bernheim's point, although it is not especially important to my argument. Second, these incentives are of dubious normative propriety; the social costs of the early transmission of wealth may outweigh whatever social benefits flow from breaking up large concentrations of wealth. Indeed, the estate tax will not even necessarily break up wealth concentrations if strategic gifts are involved, such as those facilitated by Crummey-type devices. Third, the problem underscores the unpopularity and impracticability of gift and estate taxation, and thus points to a tension between such taxation and liberal egalitarian theory. The problems highlight the necessity of a search for alternatives, which I attempt in Part V.

\section{Consumption-Savings and Work-Leisure Decisions}

The relationship, or lack thereof, between the traditional tax policy views of estate and income taxation is rather odd. The literature on income taxation has long questioned the wisdom, efficacy, and fairness of levying taxes on capital. ${ }^{131}$ Increasingly, the literature has questioned the wisdom of upwardly graduated marginal rates, even as a means for furthering the goals of progressivity, noting that there are ways to make the tax system redistributive without such a rate structure. ${ }^{132}$ The literature has reached a rough consensus

potential contributor is comparing an undiminished charitable contribution to a diminished bequest to others. See discussion infra part V.C.3.

129. See, e.g., Aaron \& Munnell, supra note 6, at 132-39.

130. See generally Langbein, supra note 116 (discussing transmission of intellectual capital to young children as 20th-century revolution in wealth transmission).

131. MuLL, supra note 48, at 165-66, 173-74, 178; see also SMITH, supra note 92, at 809-15; Summers, supra note 89, at 542. But cf. Atkinson \& Sandmo, supra note 89, at 546 (concluding that "there is no strong reason to suppose that the exemption of saving is desirable on efficiency grounds"); Feldstein, supra note 89 (noting complexities in measuring welfare costs of tax on capital).

132. See generally Joseph Bankman \& Thomas Griffith, Social Welfare and the Rate Structure: $A$ 
on the perils of high marginal rates, and this consensus has taken practical shape, at least for now, in the Tax Reform Act of $1986 .{ }^{13}$ Rates have come down, and a special sensitivity toward the effective rate on capital appears most recently in the 1993 Tax Act's holding the line at a 28\% capital gains rate. ${ }^{134}$

In contrast to this debate and the parallel developments in the income tax arena, the estate tax remains a steeply progressive tax that is levied only on capital, and there is even periodic talk of raising it. Liberal egalitarianism, with its potentially sharp distinction between intra-generational use and intergenerational transmission of wealth, might explain the apparent tension. So, too, might the early, naive theories on why people save. It seems implausible, however, that the incentive effects so dreaded in the general comprehensive tax area could be wholly absent from the estate tax field, especially given our richer understanding of savings behavior. The estate tax may be exerting adverse incentive effects on the consumption-savings and work-leisure decisions of the very wealthy, an extremely important class for purposes of both capital accumulation and prior liberal principles. Once again, this raises problems on specifically liberal grounds.

Consumption-savings and work-leisure effects stand in some lype of tradeoff with the inter vivos gift incentives discussed above. To the extent that we allow escape valves from the wealth transfer tax regime, we do not necessarily chill taxpayers who are motivated by a desire to leave bequests. Nor do we deter even those purely self-regarding taxpayers making strategic inter vivos gifts. We may not want these escape valves, however, because of their normative and economic costs. But if we somehow close the loopholes and make it impossible for a taxpayer to pass on her wealth to her heirs, we face another problem: We will impact consumption-savings and work-leisure decisions. Stiglitz argues that the best that we can hope for when implementing a tightened estate tax along with other changes designed to keep the capital stock constant is a greater equality of wealth and income purchased at the cost of a greater inequality of consumption. ${ }^{135}$ This trade-off raises a difficult "equality of what" question, to which I presently turn. "'s

New Look at Progressive Taxation. 75 CAL. L. REV. 1905 (1987) (discussing. inter alia. means of achieving progressive taxation without progressive marginal rates, through use of a lump-sum transfer or "demogrant").

133. See Joel Slemrod, Optumal Taxatıon and Optmal Tax Sistems. 4 J. ECOS. PERSP 157, $166-68$ (1990) (noting how contemporary U.S. tax reforms implement general teaching of optımal tax literature). But cf. Richard L. Doemberg \& Fred S. McChesney. On the Accelerating Rate and Decreasing Durability of Tax Reform, 71 MINN. L. REV. 913 (1987) (viewing lax reform as product of contractua! relationships between legislators and private interests and therefore questioning stability of $1986 \mathrm{Act}$ ).

134. See I.R.C. \& 1(h) (1994) (setting top capital gains rate): Carl T. Hall. Captial Gans Tax Remains At 28\%, SAN DIEGO UNION-TRIB.. Aug. 16. 1993, at C3 (discussing policy behınd 1993 Act and suggesting strategies for taxpayers).

135. Stiglitz, supra note 86 , at S137. S146-49.

136. The "equality of what" question has been a central theme in the work of Amartya Sen See AMARTYA SEN, INEQUAlity REeXAMINEd 12-30 (1992): see also G.A. Cohen. Equalisy of What' On 
For the very wealthy, the economic effects of any estate tax regime favor consumption over savings, and leisure (which can be considered the consumption of nonwork) over work. Many tax policy commentators, especially those who argue for more progressive estate taxation, presume that the very wealthy accumulate wealth for its own sake; that is, that they are wholly inelastic to any tax rate. ${ }^{137}$ An equally compelling story, however, is that the very wealthy are negatively elastic, as suggested by the behavioral responsiveness evident in large-scale inter vivos giving. One senses that the idea of complete inelasticity, reminiscent of the naive Mill position on savings behavior, would no longer have any place in income tax discussions. We have had experience with top marginal rates above $90 \%$ in the United States, and on a worldwide basis we appear to have learned our lesson: Overly high rates are inefficient and ultimately wasteful, precisely because high earners are highly elastic. ${ }^{138}$ Yet the present $55 \%$ estate tax rate, together with a combined federal and state income and payroll tax rate of approximately $50 \%$, means that a taxpayer such as Mr. Perot faces an effective tax rate of $77.5 \%$ on earned income that he bequeaths to his heirs. ${ }^{139}$

Furthermore, the antiwork and antisavings incentives may extend down to the donee level. By encouraging inter vivos gifts, the wealthy young receive their wealth, or become certain of its ultimate receipt, early in life. This wealth may undercut their incentives to work and save. Indeed, this phenomenon may be one reason why earnings revert to the mean-that is, why the children of the wealthy are apt to earn less than their parents. ${ }^{140}$ One study has shown, contrary to the prediction of the fully rational expectations model under which heirs correctly anticipate their ultimate bequests, that the receipt of sizable inheritances does indeed undermine work effort. ${ }^{141}$ Assuming that there is a

Welfare, Goods, \& Capabilities, in THE QUALITY OF LiFE 9 (Martha Nussbaum \& Amartya Sen eds., 1993).

137. See, e.g., Ascher, supra note 2, at 100-01. In Professor Ascher's view, "[t]he incentives of status and social power inherent in commanding a large fortune suggest that restricting the ability to pass one's fortune at death would have little effect on the work ethic." Id. at 101; see also MILL, supra note 48, at 174.

138. See Slemrod, supra note 133, at 166 ("[A] key message of the optimal progressivity literature, that high marginal rates may not be appropriate even for egalitarian social welfare functions, has apparently won the day.").

139. The inter vivos rate reflects a top marginal federal income tax rate of $39.6 \%$, along with other payments such as state and local taxes, social security taxes, and medicare contributions. The $77 \%$ figure is derived as follows: The lifetime tax reduces wealth by $50 \%$, and the estate tax reduces that wealth by $55 \%$, leaving $50 \%(45 \%)=22.5 \%$, for a tax rate of $77.5 \%$. There is no need for present valuc discounting, because the real tax burden remains constant across time.

140. See generally Gary Solon, Intergenerational Income Mobility in the United States, 82 AM. ECON. REV. 393 (1992) (questioning earlier studies by Gary Becker and others that found correlation of children's earnings to parents' to be 0.2 or less and finding more accurate figure to be 0.4 ); David J. Zimmerman, Regression Toward Mediocrity in Economic Stature, 82 AM. ECON. Rev. 409 (1992) (same). There are, of course, several possible explanations for this phenomenon: Children of the able arc likely to be less able than their parents; children of the rich become lazy and underproductive; children of the rich are able to develop talents and capacities not necessarily rewarded in the marketplacc.

141. See Douglas Holtz-Eakin et al., The Carnegie Conjecture: Some EmpiRical Evidence 
bequest motive, the heirs will receive their wealth in any event. Nevertheless, it may be better for them to receive their wealth later in life, say when they are fifty-five years old, than for them to receive it earlier, when their work incentives will be more affected and when their propensity to consume is greater.

On the other hand, a complete and efficacious shutting down of wealth transfers may increase work and savings incentives at the lower generations, with possibly beneficial effects on capital. Such a complete confiscation. however, would surely impact incentives at the donor level. Mr. Perot would now be comparing $\$ 3$ billion spent on himself with nothing given to his heirs: in this situation, he might decide to run an even more expensive campaign for President. As I develop more fully in Part V, there are very sound, objective political reasons why liberal society may especially fear such large-scale use by the rich-reasons that sound in prior liberal principles, as of the fair equality of opportunity. A separate and distinct argument against the loopholeshutting approach is based on pragmatic skepticism: Improved wealth transfer systems appear to be wildly unrealistic. It is worth noting that most supporters of estate taxation concede that generous exemptions will continue. ${ }^{\text {it2 }}$ We have never, for example, taxed gifts under the present income tax, and the gift and estate tax regime has always had fairly generous exemptions for annual exclusion, medical, educational, interspousal, and other gifts. Less visible matters, such as the transmission of business opportunities, pose another set of problems. There is convincing evidence, discussed below, that tighter transfer taxes are not popular, and that there is little political support for moving in the direction that most liberal theorists suggest. This raises the question of why the many might be opposed to a tax on only the privileged few. Envy and greed cannot provide an answer. Perhaps wealth transfer taxes get our objective social judgments wrong. Society actually likes work and savings, and only or at least especially dislikes excessive private use; the estate tax gets this all backwards. I return to this theme in Part V.

18-19 (National Bureau of Economic Research Working Paper No. \$118, 1992); see also Aml B Deolalikar \& R.P. Singh, The Impact of Bequests on Lufetme Wealth Accumulation. An Econometric Study of Two Generations of Rural Households in India. 36 REV. INCOME \& WEALTH 353 (1990) (finding results that suggest adverse impact of bequest receipts on wealth accumulatson of recipients) This effect may be perfectly rational. Even if an individual correctly anticipates receipt of a large inheritance, she may be unable to act presently on this antıcipation for fear that the parent, upon seeing the behavior, will change the bequest. This result is akin to Gary Becker's "rotten kid" pnneiple, "hich holds that even a truly bad child will have to hide his badness while his parents are alive See BECKER. TREATISE ON THE FAMILY, supra note 98, at 287-96. But cf. James M. Buchanan. Rent Secking. Noncompensated Transfers, and Laws of Succession. 26 J.L. \& ECON. 71.83 (1983) (arguing that potential heirs engage in inefficient rent seeking to extract bequests from their parents)

142. See, e.g., Ascher, supra note 2, at 121-49; Duff, supra note 2, at 7-8: Gractz, supra note 2. at 269-70; Haslett, supra note 3, at $137-40$. 


\section{B. Distributive Effects}

Perhaps the estate tax does not raise money, even in a cash-flow sense. Perhaps it negatively impacts the aggregate capital stock. Perhaps it encourages large inter vivos gifts and discourages work and savings among the wealthy. We may still want it. Liberal egalitarian theory, especially in its most rightsoriented incarnations, is often unmoved by these types of practical concerns. Other commonly stated justifications for estate taxation also reflect an indifference to capital and revenue effects. For example, some commentators have argued that the estate tax is concerned with "breaking up large concentrations of wealth." 143 A twist on this goal is an antihoarding position that has the arguable virtue of embracing existing loopholes: The estate tax is designed to discourage senior generations from storing up private wealth, even if this means encouraging its early, gratuitous transfer. (I know of no commentator, however, who explicitly adheres to this latter theory, which is in tension with more traditional liberal egalitarian concerns over wealth inequities extending to subsequent generations.) A common thread running through these diverse ideas is that the estate tax is primarily about questions of distribution rather than allocation, efficiency, or government revenue.

There are two distinct types of problems with such distributive concerns. One set is practical, the other more theoretical. The practical problem with most liberal egalitarian discussions is that they assume first-best taxation: Once we have figured out the right level to bar wealth transfers, we can effectively do so, damning whatever material consequences might follow. A nagging practical question, however, is whether we can truly bar the transmission of wealth. If we cannot, a gift and estate tax regime may not make sense. We have seen that the present regime encourages frequent, early, and aggressive gift giving as a way to beat the estate tax. This fact of induced tax avoidance undercuts the equal-opportunity goal, and possibly even the concerns about wealth concentration. ${ }^{144}$ The law may have a perverse, prodynasty effect, all the while diverting our attention from more productive avenues of reform.

The second, theoretical set of difficulties with distributive concerns

143. See, e.g., Bernheim, supra note 2, at 113; cf. Boskin, supra note 17, at 65 (arguing that cstate and gift taxation should be less concerned with reducing inequality in distribution of wealth and more concerned with "preventing extreme concentrations of wealth from being passed from gerleration to generation"). But cf. Graetz, supra note 2, at 271 ("In fact, however, the estate tax has done very little to dilute the greatest concentrations of wealth."). Professor Graetz, however, considers only the concentration of wealth, and not the possibility of inter-generational turnover in the identity of the wealthy themselves. See Solon, supra note 140, at 393-97, 403-05; cf. Alan S. Blinder, Inequality and Mobility in the Distribution of Wealth, 29 KYKLOS 607, 619 (1976) [hereinafter Blinder, Inequality and Mobility] ("A doubling of the tax rate, which must be considered as barely (if at all) within the realm of political feasibility, reduces both the average level and inequality of inherited wealth-but by very modest amounts. Even the ridiculous $60 \%$ tax rate has effects which are far from revolutionary. The reformer eyeing the estate tax as a means to reduce inequality had best look elsewhere.").

144. Professor Wolff suggests that inter vivos transmissions are the primary cause of wealth inequalities. Wolff, supra note 6, at 557. 
involves both the space in which we measure equality and the interplay between egalitarian and aggregative concerns. ${ }^{\text {is }}$ If we tighten the gift and estate $\operatorname{tax}$ by closing the loopholes, we run the risk of harming capital accumulation, which itself will have adverse distributive effects. If we take steps to protect the capital stock, the combined policy may increase inequality of consumption. We have not necessarily achieved a better, fairer society if the ownership of assets is more equal, but the use of wealth is less so. This outcome is especially difficult to accept under consumption tax norms, as I discuss at some length in Part V. Estate tax theory has typically focused on possession, but there are good reasons to think that unequal use is of greater moral and ethical concern for liberalism. Liberal society may reasonably conclude that the equality it seeks is most compelling when it comes to the private use of resources, where the urgency of wants has its clearest meaning. Unequal use might also correlate positively with less aggregate wealth. In any event, a properly calibrated monitoring of private use changes the nature and dangers of private possession insofar as there are distinct liberal concerns over ownership alone. The case for the estate tax on strictly liberal, progressive grounds is thus far from clear under either nonideal or ideal conditions. Indeed, the liberal economists Joseph Stiglitz and Alan Blinder, who together represented two-thirds of President Clinton's initial Council of Economic Advisors, each, independently, questioned the wisdom of gift and estate taxes some twenty years ago. ${ }^{146}$

Whatever one might think of these theoretical and design-based arguments, there is solid evidence that the gift and estate tax regime is not effectively fostering a better overall distribution of wealth. ${ }^{147}$ In the United States, wealth concentration generally has been constant throughout this century, despite the presence of a nominally steep gift and estate tax regime. ${ }^{1+8}$ The level of wealth concentration is remarkably similar across most advanced Western societies, regardless of the details of their wealth transfer regime, and also regardless of whether they even have one. ${ }^{149}$ Most commentators have interpreted this data to mean that we should tighten the gift and estate tax system. ${ }^{150}$ It is of course possible to argue that a stronger wealth transfer tax

145. See SEN, supra note 136, at 12-16. 136-38.

146. See Blinder. Inequality and Mobiluy, supra note 143, at 618-19: Blinder. Inherised Wealth. supra note 2, at 608-09; Stiglitz, supra note 86. at S137: see also Bemheim. supra note 2. at 135. Their arguments undermine the skepticism evident in Professor Graetz's remark that "[1]iberal economists will likely find little or no impact [on economic incentives from the estate tax]: conservatuve economists will probably discover serious deleterious effects." Gractz. supra note 2. at 283. As of the final wntung. Blinder had moved over to serve on the Federal Reserve Board.

147. See generally Donaldson, supra note 1, at $541-42$ (presentung evidence that gift and estate tax does not foster more equal distribution of wealth).

148. See Aaron \& Munnell, supra notc 6, at 122-27 (discussing wealth concentration in 20th. century United States); Wolff, supra note 6, at 552 (same); see also Gractz, supra note 2, at 271 (stating that concentration of wealth has remained stable).

149. See Aaron \& Munnell, supra note 6. at 127-28. Australia. Canada, and Israel have effectuvely eliminated their wealth transfer regimes. See infra nole 168.

150. See, e.g., Aaron \& Munnell, supra note 6. at 139: Eisensiein. supra note 2. at 255-59. But cf 
system would not have led to the current state of affairs, or that a weaker system would have left things worse. Yet it is not clear that we can improve the gift and estate tax system, and it is not implausible that the current system actually causes some of the real problems of maldistribution, at least by constraining the evolution of better, more liberal tax systems.

The current tax regime may be helping to break up very large concentrations of wealth; it may be somewhat effective at the very rich end, as noted above in Table $1 .^{151}$ But the connection between breaking up large wealth concentrations and equal opportunity, or the Rawlsian "fair equality of opportunity" norm, is not all that clear. Even if we agree with Rawls and concede that some sense of equal opportunity is lexically prior to the consequentialist concerns of the difference principle, ${ }^{152}$ the dissolution of high concentrations of wealth via wealth transfer taxation occurs at least at the partial expense of perpetuating a very wealthy elite, because of the induced inter vivos gifts. It may not be better for society to have one thousand millionaires, many of them quite young, than a single billionaire. ${ }^{153}$ Even this claim is undercut by the possibility of strategic gifts and bequests, which effectively keep the donor's power intact. There are also some reasons to believe that such wealth would dissipate, even without the tax. ${ }^{154}$ Finally, there is the even more troubling possibility that the current estate tax, or any confiscatory cousin, might induce the kind of large-scale personal use of wealth exemplified in the Perot presidential bid. We might be effecting the dissolution of large concentrations of wealth by inducing citizens to spend vast sums of money, perhaps by running for elected office. Such excessive personal consumption surely implicates the Rawlsian concern with "power detrimental to the fair value of political liberty and the fair equality of opportunity."155 Yet under a back-ended wealth tax, far from checking Perot's bid, the fisc served as a de facto partner in his campaign. It is high time to consider better alternatives.

COOPER, supra note 2, at 90-111 (suggesting more comprehensive reforms beyond improved enforcement of existing gift and estate tax regime); McNulty, supra note 28, at 94 ("Much could be said in favor of repealing transfer taxes altogether and enacting nothing to replace them.").

151. See Boskin, supra note 17 , at $65-66$.

152. See THEORY OF JUSTICE, supra note 19, at 89, 300-01; see also KYMLICKA, supra note 22, at 53-54 (noting schemes of lexical priority within $A$ Theory of Justice).

153. On a trivial level, most wealth transfers are equality enhancing, because the parent-transferors are wealthier than the children-transferees. See Stiglitz, supra note 86, at S147-48. Such transfers nonetheless raise hard questions, because they create intra-generational disparities at the transferee level.

154. See Boskin, supra note 17, at 65-66 ("While multiple heirs, regression toward the mean, and other forces tend to make voluntary bequests a force for equality - not inequality - in our society, perhaps reducing the tax incentives to trust formation would speed up somewhat the dissipation of large fortunes."); Solon, supra note 140, at 393-94 (finding tendency to revert to mean, though weaker than previous authors had found); Zimmerman, supra note 140, at 409-10 (same). Kotlikoff suggests that altruistic linkages across extended family networks may be quite significant. KOTLIKOFF, WIIAT DETERMINES SAVINGS?, supra note 94, at 41-42.

155. THEORY OF JUSTICE, supra note 19, at 277. 


\section{LOOKING for Alternatives: TOWARd a POLITICAL Theory of TAX}

Part III argued that the estate tax is complicated and porous, may lose money, and almost certainly negatively affects the capital stock. Part IV argued further that the behavioral incentives toward inter vivos gifts and consumption. and away from work and saving, call into question the liberalism of the tax regime. There is little evidence or hope that an improved distribution of resources justifies the tax. Nor is there much practical or theoretical support for responding to problems by strengthening the tax. Dilemmas abound; if we tighten the tax, we increase the incentives to consume while causing a decrease in the capital stock. This Part turns to a search for better alternatives. In particular, I argue for comprehensive reform, featuring a progressive consumption-without-estate tax.

Recalling the five liberal arguments against wealth transfer taxation set forth in Part II, this Part assumes that the first argument has been established-that is, that the current estate tax is ineffective at best and counterproductive at worst. This Part completes the second argument, implicit throughout Parts III and IV, that a confiscatory or strengthened alternative is neither popular nor practical. This Part then presses the related third and fourth arguments, namely that any form of wealth transfer tax is inappropriate as a matter of both nonideal and ideal liberal theory, while constructing the fifth argument, that a progressive consumption-without-estate tax is the best political liberal tax system.

A word on semantics and organization is in order. Although I believe that there is nothing magic in the labels of "income" or "consumption," and my preferred alternative intentionally blurs the distinctions, framing the subsequent discussion in these familiar terms will facilitate connections with both classical and contemporary tax policy theory. Section A discusses the role of wealth transfer taxes under a traditional income-plus-estate tax. It argues that small or incremental changes to the status quo, such as raising rates or tightening one or both taxes, are apt to fail. Section B discusses the possible roles of wealth transfer taxation under a broad-based consumption tax. While emphasizing that many of the norms of consumption tax theory are both independently attractive and already implicit in our practices, I argue that these norms require a departure from the traditional liberal case for flat-rate consumption taxation, as seen in Mill and Rawls, and also call into question the practical wisdom of any wealth transfer tax. These consumption tax norms counsel for a consistent and objective focus on the use of wealth, as opposed to its mere possession.

Finally, in Section C, I explicitly consider the reform proposal that best comports with the underlying norms of consumption tax theory and our observed practices: a progressive consumption-without-estate tax. This proposal brings together all of the themes of the preceding discussions and seeks to 
unify the ideals of liberal theory with the often-inchoate spirit of our actual settled practices. It also reemphasizes that the best and most feasible tax system on liberal grounds is one that does not include any wealth transfer tax at all.

\section{A. An Income-plus-Estate Tax}

The most commonly touted liberal tax system is a progressive incomeplus-estate tax, which is what we already have, at least in name. But problems with the income tax exist on both a theoretical and a practical level. In theory, an income tax is based on one's "ability to pay." Income, however, is a poor proxy for ability, even in theory, and this incongruence might partly explain why liberal egalitarian philosophers from Mill to Rawls have tended to favor a consumption tax. In practice, we have never come very close to a true income ideal. The realization doctrine, pension taxation, the rules for owneroccupied homes, human capital, insurance provisions, and many other deeply embedded aspects of the law, including the entire payroll tax system, have moved us squarely toward a consumption tax model. Society seems to have accepted much of the logic of the consumption tax, though we remain troubled by wealth and its unequal distribution. Thus, we have an "income" tax that is actually a complex hybrid of income and consumption taxes, supplemented by an estate tax. ${ }^{156}$

It is clear, however, that a motivating factor behind any advocacy of an income ideal is the thought that the mere possession of wealth matters. ${ }^{157}$ If use alone were the concern, then consumption tax theory would suffice. ${ }^{158}$ Similarly, if efficiency were the primary concern, then the consumption tax would seem to prevail under a technical analysis involving elasticities, general equilibrium, and so on. ${ }^{159}$ Thus, we may evaluate the income-plus-estate tax vis-à-vis my preferred progressive consumption-without-estate tax, or vis-à-vis any other alternative, based on its relative ability to attack privately held but unspent wealth.

156. Andrews has emphasized the hybrid nature of the income tax. See Andrews, supra note 61, at $1117,1120-21$. See generally UNEASY COMPROMISE, supra note 87; McCaffery, Hybrid, supra note 5.

157. See Graetz, supra note 2, at 271-73; Alvin C. Warren, Jr., Fairness and a Consumption-Type or Cash Flow Personal Income Tax, 88 HARV. L. Rev. 931,943 (1975) [hereinafter Warren, Fairness): Alvin Warren, Would a Consumption Tax Be Fairer Than an Income Tax?, 89 YALE L.J. 1081, 1122-24 (1980) [hereinafter Warren, Consumption Tax].

158. The same point can be understood with reference to the accounting identity that gives form to the Haig-Simons definition of income: Income equals consumption plus savings. See HENRY C. SIMONS, PERSONAL INCOME TAXATION 50 (1938). The income base differs from the consumption one solely in its inclusion of unspent, or "unused" wealth.

159. See generally Alan J. Auerbach et al., The Efficiency Gains from Dynamic Tax Reform, 24 INT'L ECON. REV. 81 (1983) (suggesting large welfare gains from not taxing capital); Don Fullerton ct al., Replacing the U.S. Income Tax with a Progressive Consumption Tax, 20 J. PuB. ECON. 3 (1983) (same); Summers, supra note 89 (same). But cf. Feldstein, supra note 89 (questioning welfare costs of tax on capital). 
It is therefore a significant problem that the present income-plus-estate tax seems not to be curtailing the private possession of wealth in practice or in theory. Even advocates of the current regime concede that the system is doing little if anything to lessen the unequal distribution of wealth. ${ }^{100}$ The flawed income tax allows large amounts of wealth to build up intra-generationally. Very few individuals or families pay any gift or estate tax at all, and, as I have noted repeatedly, the total yield of the gift and estate taxes is quite low. Such taxes may succeed in preventing an excessive concentration of wealth, but only by pushing people to give to their descendants inter vivos, to give to charity, to consume, or simply not to earn wealth in the first place. In any event, the relative distribution of wealth in society seems to be rather constant across time and throughout various advanced Western cultures; it matters little, either temporally or cross-culturally, whether any form of wealth transfer taxation is in place. ${ }^{161}$

Given these problems with existing methods of attacking private wealth, some change would appear to be needed on liberal grounds. Suppose, first, that we tried to tighten the estate tax, keeping the present income tax in place. Higher estate tax rates would further discourage work and saving and encourage conspicuous or large-scale consumption. At the same time, the gift and estate tax system has, and likely will continue to have, holes of such magnitude that it will continue to encourage the inter vivos transmission of significant amounts of wealth. Any such move to tighten estate taxation would also face significant political and practical difficulties. Estate and inheritance taxes are not especially popular, here or in other cultures, now or ever. ${ }^{162}$ The present income tax has never included gifts or bequests within the tax base. ${ }^{163}$ A popular uproar of opposition greeted George McGovern's proposal for a radical tightening of the wealth transfer taxation regime. ${ }^{\text {tot }}$ After

160. See, e.g., Aaron \& Munnell, supra note 6. at 119. Graetz. supra notc 2, at 271 1"In fact, however, the estate tax has done very little to dilute the greatest concentrations of wealth ") For other views that criticize the current regime and question the estate tax ${ }^{\circ}$ effects on "wealth distribution. $x e c$ Blinder, supra note 143, at 618-19; Boskin. supra note 17. at 63-64: John K McNulty. Public Polus and Private Charity: A Tax Policy Perspective, 3 V.. TAX REV. 229. 252 (198.4)

161. Aaron \& Munnell, supra note 6, at 127-28.

162. See, e.g., Aaron \& Munnell, supra note 6, at 132-39: Gractz, supres note 2. at 284-85. Haslett. supra note 3, at 142 ("[T]he simple truth is that Amencans are solidly against labolishing inheritances]."). One commentator who favored cstate taxes mused about why they are not used more extensively: "A possible explanation is that equalization of the distribution of wealth by taxatton is not yet accepted in the United States." PeChMAN, supra note I, at 236.

163. In contrast, the income tax of 1894 explicitly provided for the inclusion of "money and the value of all personal property acquired by gift or inheritance." Act of Aug. 27. 1894, ch 34, $\$ 27,28$ Stat. 509. 553. The Supreme Court invalidated the law in Pollock v. Farmen' Loan \& Trust Co, 157 U.S. 429,607-08, aff'd on reh'g. 158 U.S. 601 (1895). Commentators frequently pount out that the present income tax-as it has existed since 1916-has never taxed gifts or bequests See, \&. Wilitam A. Klein. An Entgma in the Federal Income Tax: The Meanng of the Wont Gift . 48 MIN L REV 215, 215 (1963); Marjorie E. Kornhauser. The Constumuonal Meanng of Income and the Income Taxation of Gifts, 25 CONN. L. REV. 1, 1-2 (1992); see also Joseph MI Dodge. Besond Estule and Gift Tax Reform: Including Gifts and Bequests in Income. 91 HARV. L. REV 1177. 1180-88 (1978)

164. McGovern: "Jobs Are the Comerstone of My Polks". WWASH POST. Aug 30, 1972, at A12 
Congress drastically reduced gift and estate taxes in 1981, a poll revealed that $57 \%$ of Americans favored the change. ${ }^{165}$ In 1982 , fully $64 \%$ of Californians voted to repeal the inheritance tax, which applied potentially to only $5 \%$ of them. ${ }^{166}$ More recently, $49 \%$ of the respondents to another poll said that an increase in gift and estate taxes was an "unacceptable" way to pay for national health insurance, while only $14 \%$ said that it was a "good" way to do so. ${ }^{167}$ Australia, Canada, and Israel, all Western democracies where liberal egalitarian ideals may be said to have some sway, have recently eliminated their wealth transfer tax systems. ${ }^{168}$ A recent House of Representatives resolution, cosponsored by 162 legislators, opposed any increase in the effective rate of estate taxation, in part "because such measures contradict the fundamental goal of the United States Government of encouraging long-term private saving."169 While there are various potential interpretations for the unpopularity of wealth transfer taxes-my preferred interpretation, of course, is that the people are right on strictly liberal grounds-I mean to emphasize here only that the fact of popular opposition poses problems for a potential reformer. ${ }^{170}$

(text of McGovern's remarks); see also THEODORE H. WHITE, THE MAKING OF THE PRESIDENT 1972. at 118-19 (1973); Graetz, supra note 2, at 285.

165. Support Erodes for the Business Tax Cuts, Bus. WK., Apr. 12, 1982, at 18.

166. California legislators abolished the gift and inheritance tax, leaving only a "pickup tax." a device for returning some of the federal estate tax to the state fisc. See CaL. Rev. \& TAx. Codz $\S \S 13301-13304$ (West 1994).

167. Telephone Poll by Peter D. Hart Research Associates (Apr. 20-23, 1992) (polling 1004 registered voters). Thirty-one percent indicated that an increase in estate and gift taxes was "acceptable if necessary." Among other potential methods of financing that the poll mentioned, the respondents considered only two taxes more "unacceptable" than the increased estate and gift tax: an increase in the tax on gasoline (60\% said "unacceptable") and an increase in the tax on Social Security benefits that the high-income elderly pay (63\%). The respondents considered all other methods of financing to be less "unacceptable" than estate and gift taxes: an increase in liquor and cigarette taxes (23\% said unacceptable), an oil import fee (40\%), an increase in payroll taxes for employers (46\%), a national sales tax $(44 \%)$, an increase in payroll taxes for employees (47\%), an increase in personal income taxes for households earning more than $\$ 50,000$ a year $(24 \%)$, and an increase in personal income taxes for households earning more than $\$ 20,000$ a year $(48 \%)$. Id.

168. See International Tax Summaries: A Guide for Planning and Decisions at A-47, C-9, 1-73 (George J. Yost III ed., 1993) (Australia, Canada, and Israel, respectively). In Australia, the government abolished estate and gift duties in 1978, despite the fact that the Labor Party had argued for the taxes "to combat undue concentration of inherited wealth, to promote equality of opportunity, and to provide needed revenue ...."Willard H. Pedrick, Oh. To Die Down Under! Abolition of Death and Gift Duties in Australia, 35 TAX LAW. 113, 116 (1981).

In Canada, the federal government abandoned estate taxes in 1971. Richard M. Bird, The Case for Taxing Personal Wealth, in RePORT OF THE PROCEedings of THE TWENTY-THIRd TAx CONFERENCE, 1971, at 6 (1972). One reason that Canada abolished the federal estate tax was that "the revenues were small and the aggravation enormous." Douglas G. Hartle, Some Analytical, Political and Normative Lessons from Carter, in THE QUEST FOR TAX REFORM 397, 418 (W. Neil Brooks ed., 1988). Although many provinces continued to tax wealth transfers on death for a while, they have all since abandoned such taxes. Id. On the Canadian experience with wealth transfer taxes, see generally RogER S. SMITH, Personal Wealth Taxation: Canadian Tax POLicy in a Historical and an International SETTING (Canadian Tax Paper No. 97, 1993).

In Israel, the government eliminated inheritance taxes in 1981 as part of a supply-side program that included tax cuts and savings incentives. Harry Anderson, lsrael's Supply-Sider, NEwSwEEK, Apr. 6, 1981, at 70; Jeff Braide, Inheritance No Longer Liable to Taxation, JERUSALEM POST, June 7, 1990, at 8.

169. H.R. Con. Res. 6, 103d Cong., Ist Sess. (1993).

170. See Duff, supra note 2 (noting and discussing problems generated by unpopularity of taxcs). 
Beyond this political opposition, there are practical problems. Altempting to tax small gifts, whether under the income tax (to the donee) or under the gift and estate tax regime (to the donor), poses significant problems of valuation and administration. Much wealth transmission takes place in the form of hard-to-police opportunities and the passing on of knowledge. It is almost certain that some provisions-for example, for gift exclusions of some amount and for transfers for education and medical needs-would survive any reform. It is noteworthy, though not surprising, given the above, that virtually every advocate of a tightened estate tax, including those who argue openly for "confiscatory" taxes, concedes that rather large exemptions will survive." Many of the changes advocated in the existing tax literature, such as a tightening of "estate freezes" or GSTs, have indeed been enacted, but in a form that preserves many planning opportunities. These changes may even aggravate existing problems by establishing a clear means for minimizing the tax. ${ }^{17}$ The net effect of any tightening that left some exemptions in place, especially

The common explanation for popular opposition to gift and estate taxes is that the ordinary citizen believes that she might one day inherit a large sum of money or come into a large sum that she will want to pass on. See Ascher, supra note 2, at 119-21 (quoung presidentual candidate George MlcGovern's press spokesperson explaining public reaction to McGovern's proposal to severely limit inhentance "It would wipe out the dream factor-every slob in the strect thunks that if he huts the lottery big. he may be able to leave half a million to his family ....") (aheration in origual). Graek, supra note 2. at 285 ("The only convincing explanation [of estate taxation's unpopulanty] that has oceurred to me lies in the optimism of the American people."): Kirchheimer. supra note 3, at 1233 (noung that "George Couper. a former tax law professor at Columbia University, sald the only satusfacton explanation for the outery against estate taxes is the "lottery mentality' of the Amencan public." and that Canadian cconomist Richard Bird attributed opposition to Canadian estate tares to "'a lot of mytholog.." because ".. [m]ost people were afraid of a tax they never would have been exposed $10^{* *}$ ). Quite a different explanation, of course, is that people do not like the estate tax for many of the same reasons why economists do not like it-for example, because it penalizes thrft and virue People's intuitions ma) well favor the careful bequest saver over the conspicuous spender, and they may feel that inheritance is a natural and salutary process, at least within very wide ranges. The estute tax's unpopulaniy casts doubt on an cniy explanation, unless the particularly strong envy of a relatuely small number of indisiduals can explasn the presence and persistence of the tax. Sec discussion infra note 259

171. Professor Ascher, for example. sets the limu at $\$ 250.000$ and would seem to allow educattonal and medical transfers, along with a $\$ 5000$ annual gift exclusion Ascher. supra note 2. at 126-35 A one time transfer of $\$ 250,000$ would grow to over $\$ 266$ million over a 70 -y ear life at a 10 rs rate of return. an annual gift of $\$ 5000$ would grow to over $\$ 2.2$ million over a $40-3$ ear penod at a $10 \%$ rale of return For a 70-year period, which is what grandparents and parents might be able to sustann. 55000 a year at a $10 \%$ rate of retum would grow to over $\$ 39$ million Once agann. we double the numbers if both parents are involved.

172. Commentators have long advocated restrictions on generation-shipping gifts See, \& . COOPtR. supra note 2, at 94; Max Gutierrez. Jr. Taxation of Wealih Transmission Problems and Reforms. in DEATH, TAXES AND FAMILY PROPERTY, supra note 2. at 71. 76-78 The result was the promulgation of the GST in 1986, see I.R.C. $\$ \$ 2601-2663$ (1994), which has numerous holes that I have already mentioned. Similarly, discussion of estate freezing has increased in recent jears. see, e $g$. Dodge. supra note 2, at 309-16: McCaffery. Estase Freeze. supra note 117, resultung in the passage of a nen Chapter 14 in 1990. I.R.C. $\$ \$ 2701-2704$. Practitioners have quichly developed sanous desices-most prominently GRITs (grantor retained income (rusts) and GRATs (grantor retained annuity trusts)-to deal with these laws. See, e.g. Thomas W. Abendroth. Grantor Trusts Are Now Useful Planning Tools. 20 TAX'N FOR LAW. 81 (1991): Benton C. Strauss \& James K. Shaw. Final Chupter if Regs Clarif GRATs, Business Planning, 19 EST. PLAN. 259 (1992). Donaldson discusses some of the reform proposals that have not yet been enacted; he, like me, is skeptical of how much improvement they would in fact generate. Donaldson, supra note I, at 552-57. 
with continued high marginal rates, would be to put an even greater premium on taking advantage of all such escape valves. Unproductive planning costs might rise. Lurking around the corner from any tightening may just be increased consumption and decreased work effort and capital.

The type of practical, administrative concerns mentioned in the preceding paragraphs may seem out of keeping with the sometimes symbolic focus of the present law or of ideal liberal theory. To draw a contrast, however, many of the consumption tax advocates discussed in the next Section, including Nicholas Kaldor and William Andrews in particular, favor the consumption tax largely because of the unattainability of a pure income tax ideal, and because of the distortions that flow from an only partial embrace of income taxation. ${ }^{173}$ Yet such authors and many others are quick to tack on a gift and estate tax, with barely a word on the practical difficulties of such taxes, or on the distortions that imperfect, real-world wealth transfer taxes produce. Practical problems are relevant and possibly decisive as a matter of nonideal theory, and, under an interpretive turn, are also relevant for ideal theory. There comes a time when policy ought to learn from practice, as it did in the move from income tax toward consumption tax theory. In the case of the gift and estate tax, we might learn something from both its deep unpopularity and its many exceptions, here and in other countries, now and for a long time past, most of which are deeply grounded in settled intuitions and practices. Popular opposition and practical constraints, often popularly compelled, have vitiated the effectiveness of wealth transfer taxation. There is little reason now to have confidence in even tightening the regime; it is time to look for new and different answers to old problems.

Problems would also arise on the income tax side of any income-plustightened-estate tax scheme. Contrary to its apparent underlying ideal, the present income tax actually tolerates significant inequities of wealth. Rates today are not terribly high by historical standards. ${ }^{174}$ Indeed, a large practical and political problem with our fidelity to an ostensible income tax has gone all but unnoticed in the literature, perhaps obscured by the conceptual link between consumption and flat-rate taxes: The adverse effects on work and savings incentives constrain the income tax rate structure, whereas it is primarily the adverse effect on consumption incentives that constrains rates under a consumption tax. ${ }^{175} \mathrm{~A}$ consumption tax can therefore tolerate higher

173. See Nicholas Kaldor, Comments, in WhAT Should BE TAXED: INCOME OR EXPENDituRE? 151-57 (Joseph A. Pechman ed., 1980); William D. Andrews, Fairness and the Personal Income Tax: A Reply to Professor Warren, 88 HARv. L. REv. 947, 947 (1975) [hereinafter Andrews, Fairness]. Of course, it seems a little odd that supporting the consumption tax on second-best grounds should lead to an insistence on a "pure" consumption tax, although support has not led to such insistence by Andrews, who advocates progressive rates. Id. at 956; see also infra part V.B.

174. The current top marginal income tax rate is $39.6 \%$. I.R.C. $\S I(a)(1)$. This figure is low by historical standards. See PECHMAN, supra note I, at 313-14 tbl. A-1 (showing historical top bracket rates); Slemrod, supra note 133 , at 166.

175. This point depends to some extent on the absence of adverse incentive effects under the 
rates on higher dollar levels, as I discuss below. Income tax theory gets tangled up in the same paradox that plagues the gift and estate tax: Short-run distributive goals may be in tension with macroeconomic and independent normative goals that have their own long-term, liberal distributive benefits. Indeed, we can now see the basic outlines of a dynamic of political counterproductivity. If tax is in the end all politics, as I am arguing, we would expect at least the broad features of our tax system to reflect objective social values. But there is tension if the experts hand down to the people institutional tax systems that themselves conflict with sound liberal judgments. The people cannot be overly "progressive" under an income-plus-estate tax, because this regime punishes behavior that a liberal society reasonably condones (work, savings, and bequests), and it induces behavior that a liberal society reasonably suspects (leisure, consumption, and large inter vivos transfers).

Somewhat ironically, liberal advocates of both income and estate taxation sometimes cite "progressivity" as a reason to support these taxes. ${ }^{176}$ The reasoning is elementary: Since only the wealthy pay estate taxes, such taxes appear to add to the overall system's progressivity. ${ }^{177}$ But there are at least three severe and related problems with this reliance on progressivity. First, progressivity is not obviously an end in itself, particularly if we rule out envy as a legitimate concern. ${ }^{178}$ Rather, progressivity must play whatever role it is to have as a component of a larger theory of justice. Rawls himself opposes excessive reliance on progressivity, believing instead that progressive rates are best limited to wealth transfer taxes, without even invoking the difference principle: "It may be better, therefore, to use progressive rates only when they are necessary to preserve the justice of the basic structure with respect to the first principle of justice and fair equality of opportunity . . . ."179

Second, progressivity is hard to measure. The argument that estate taxes are "progressive" is a decidedly static one. The ostensible burden of the

progressive consumption tax. See discussion infra par VC.2. Note that Prolessor Graetz. an open advocate of more progressive tax systems. favors tighiening the estate tax over raising income tax rates. see Graetz, supra note 2, at 270-78, 284, because of the adverse incentuve effeets of the latter Id at 273 ("High income tax rates both create marginal disincentives to productivity and stumulate legal and illegal noncompliance."). Later, I suggest that we can escape from this particular dilemma under a progressise consumption tax.

176. E.g., Graetz, supra note 2, at 273: Gutman, supra note 2, at 1188 . See genterall, Donaldson. supra note 1 , at $543-45$ (discussing progressivity as rationale for estate tax)

177. Graetz, supra note 2, at 271.

178. See THEORY OF JUSTICE, supra note 19, at 530-41. See generally Robert Young, Egalitarianism and Envy, 52 PHIL. STUD. 261 (1987). For an excellent example of an attempt to ground progressivity on clear and independent normative foundations and to illustrate varying means of implemenung progressive norms (including, paradigmatically, through a non-progressive marginal rate structure), see generally Bankman \& Griffith, supra note 132.

179. THEORY OF JUSTICE, supra note 13, at 279 (emphasis added) Later on the same page. however. Rawls notes that "even steeply progressive income taxes" may be appropnate "given the injustuce of existing institutions." Id. Rawls' use of the word "even" underscores the extent to which he considers a progressive income tax to be far removed from ideal theory. To dnve the point home. Rawls adls explicitly that "[t]wo wrongs can make a right." Id. 
income tax, for example, fails to reflect the imputed and psychic income from leisure. Looking at the estate tax is even more problematic, because its visible burdens do not reffect the increased consumption, leisure, and inter vivos giving of its putative targets. The very rich who spend all of their wealth on themselves do not add to the static progressivity figures, and yet these parties may be the ones of greatest concern to the liberal. If Mr. Perot were to spend all of his $\$ 3$ billion running for office, say, we would get no part of our "progressive" result from him.

A third and related problem is that even if we want progressivity as an end and are prepared to accept some real-world measurement as a suitable proxy for what really counts, it matters where we get it. Use of the estate tax to provide progressivity burdens those manifestly few individuals who want to leave bequests but do not plan well for it; at the same time, it ignores and even encourages greater lifetime consumption and inter vivos gifts among those who do plan. An estate tax may not be the most effective way to achieve whatever progressivity we do desire in the tax structure. It may be better, as I argue below, to levy the burden of progressivity on the act of private, preclusive use within an essentially consumption tax structure. This option acts on what the people and our evolved practices are trying to tell us in resisting any real, effective estate tax, in moving toward a consumption base, and in maintaining at least moderate progressivity.

In any event, the (relatively) low rates of the present income tax, combined with the numerous ways of escaping taxation on the yield to savings, allow for significant private accumulations of wealth over the course of a lifetime. The H. Ross Perots, the Michael Milkens, the Bill Gateses, and countless other first-generation, highly wealthy individuals of this world are at least anecdotal testimony to the ability of individuals to amass private fortunes under the current tax regime. Combining the present income tax system with a tightened estate tax runs the risk of significantly accentuating conspicuous or large-scale private consumption. Arbitrage between the consumption and income models is a simple matter within a lifetime. The Perots or the Milkens are free, under the income tax, to build up large stores of private wealth, using, say, appreciating property. If the estate tax were our only "backstop" to the holes that the income tax generates, these individuals could spend down their wealth, perhaps by borrowing against it, without triggering any income tax consequences. ${ }^{180}$ Our current tax plan promotes large lifetime accumulation of wealth along with its rapid dissipation during that lifetime, all the while

180. In fact, the wealthiest estates are far more likely to have debt-and to have much larger average debt-than those closer to the taxable threshold. See Johnson, supra note 56, at 92-95 tbl. 2. Over $62 \%$ of the wealthiest estates (gross estates over $\$ 20$ million) had debt, while less than $26 \%$ of estates in the lowest category (under $\$ 1$ million) had debt. In fact, this percentage rises monotonically with wealth brackets. Id. There are, of course, several possible explanations for this effect, including the self-selection for risk preference and the importance of debt in accumulating wealth. 
discouraging any form of long-term, inter-generational savings. Such an incentive structure hardly seems sensible. The Perot presidential run, for example, seems squarely to implicate Rawls' concern with "concentrations of power detrimental to the fair value of political liberty and fair equality of opportunity," 181 and yet the current tax system levies no tax on that act-indeed, it encourages it. Likewise, an income-plus-estate tax places no constraint whatsoever on the use of wealth by heirs.

The current tax system makes treacherous any arguments about leveling the playing field or promoting equal opportunity. Interestingly, the very ideal of income taxation calls into question the liberal egalitarian's willingness to accept varying intra-generational outcomes as fair, as reflected in Mill's and Rawls' calls for a proportionate consumption tax. In moving away from this acceptance of intra-generational divergences, the income tax advocate implicitly calls into question any radical distinction between intra- and intergenerational outcomes. But then all inequality becomes suspect, whether or not traceable to individual lifetime efforts, and we ought to be asking more openly consequentialist (or at least different) questions about how to curb inequality. Once again, we can ground this inquiry in nonideal or ideal theory. Nonideal theory may lead us away from any meritocratic view of earnings; conversely, ideal theory may suggest that the income tax's focus on earnings, even if earnings are indeed "fairly" come by, is misplaced. The ethical and political logic of progressivity under an income tax-at least within a liberal as opposed to a utilitarian conception-shows no logical stopping point. While some have concluded that this lack of a stopping point makes the case for progressivity "uneasy,"182 I conclude to the contrary that it means the case is political. ${ }^{183}$ But if all tax is political, we need to look even more closely at our practices; the metaphysics of earnings do not afford us an easy way out. Ironically, perhaps, or at least counter-intuitively, an invigorated estate tax does not necessarily move us in any normatively attractive direction.

Rather than changing the estate tax, therefore, we might attack the possession of wealth through a tightened income tax. I believe that there are good reasons, once again grounded in liberalism and sound objective judgment, to reject a tighter income tax. These reasons have checked any real, practical implementation of the income ideal, much as a parallel set of reasons has blocked any meaningful estate tax; once again, interpretive and independent

181. THEORY OF JUSTICE, supra note 19, al 277.

182. The leading statement of the uneasiness of the case for progressivily is found in WALTER J Blum \& HaRry Kalven. THe UNEASy CASE for Progressive TAXation (1953), to which the tulle of this Article pays tribute. See also Bankman \& Gnffith, supra note 132 (critıcizing Blum and Kalven and advancing utilitartan or welfarist defense of progressivity, along optumal (xxatıon lines)

183. Arthur Ripstein takes a similar view about the political status of arguments for luck and responsibility evident in our tort system. See generally Arthur Ripstein. Equalisv. Luck. and Responsibility, 23 PHIL. \& PUB. AFF. 3 (1994) (arguing that concept of responsibility has been employed for liberal ends in tort law). 
normative reasoning converge. But let us imagine, to flesh out this one point, that we did have a purer income tax. ${ }^{184}$ How would the estate tax fit under this ideal income tax regime? The answer is problematic. As the incomeversus-consumption debate highlighted, an ideal income tax burdens deferred consumption relative to present consumption by penalizing work and savings, and pushing toward leisure and use. Any estate tax burdens bequests even further, doubling the push toward consumption and away from work and savings for the richest citizens, an important group when it comes to savings and consumption decisions. If a true income tax "doubly" taxes savings, as Mill alleged, ${ }^{185}$ an income-plus-estate tax triply taxes bequest savings.

Since the ideal income tax hits hard at wealth, there may be little need for the estate tax as a "backstop." In point of fact, the estate tax as a backstop to the current income tax works in two directions. At the donor's level, the estate tax compensates ex post for the failure of the income tax to have addressed wealth concerns. At the donee's level, it compensates ex ante for the failure of the income tax to get at the subsequent appreciation of the bequest. An ideal income tax solves these two problems and thus diminishes the appeal of, or need for, a tightened estate tax. More appealing is an ideal income tax without an estate tax. The ideal income tax provides for continuous taxation of the yield to capital; eliminating the estate tax simply moves toward putting bequests on the same footing as all other future consumption.

In sum, even if we are concerned about the possession of wealth, the present flawed income-plus-estate tax seems ineffective both in theory and in practice. Fixing or tightening the income tax seems to be a better way of addressing concerns over wealth than tightening the estate tax, because many of the problems of inequality are intra-generational ones; the estate tax is apt to be porous at best; and a flawed income-plus-tightened-estate tax runs the risk of encouraging large-scale consumption and early, frequent inter vivos transfers. If we instead tighten the income tax, then we weaken the reasons for having any estate tax at all. Including an estate tax with a tightened income tax

184. Any improved income tax would almost certainly have to overcome the barricrs to the ideal posed by the realization requirement, first set forth in Eisner v. Macomber, 252 U.S. 189 (1920). See generally Andrews, Consumption-Type, supra note 61 (tracing tax system's major deficiencies to imperfect taxation of savings or accumulation). Indeed, an increasingly sophisticated literature has been giving us means to do so. See, e.g., Alan J. Auerbach, Retrospective Capital Gains Taxation, 81 AM. ECON. REv. 167 (1991); Noel B. Cunningham \& Deborah H. Schenk, How To Tax the House that Jack Built, 43 TAX L. REv. 447 (1988); Mary Louise Fellows, A Comprehensive Attack on Tax Deferral, 88 MICH. L. REV. 722 (1990); David J. Shakow, Taxation Without Realization: A Proposal for Accrual Taxation, 134 U. PA. L. REV. 1111 (1986); Jeff Strnad, Periodicity and Accretion Taxation: Norms and Implementation, 99 YALE L.J. 1817 (1990). See generally Karla W. Simon, Revenue or Religion? Issues and Answers on Tax Deferral, 68 TAXES 1015 (1990) (providing broad overview of attempts to overcome the realization requirement).

185. MILL, supra note 48, at 816-17. Commentators asserting that the double tax argument takes an ex ante perspective have strongly contested this claim. See Warren, Consumption Tax, supra note 157, at 1099-1101. It is beyond dispute, however, that an income tax hits savings harder than a consumption tax-that is the point of the distinction between an income and consumption tax. 
undermines incentives to work and save for taxpayers with any bequest motive, and pushes, once again, toward excessive consumption and the earlier transmission of wealth. Since our accumulated practical wisdom lends little support to a stronger income tax regime in any event, all of this analysis mainly just serves to reaffirm the need for a continued, broader, and more imaginative search for alternatives that are more consonant with our ideals.

\section{B. A Consumption-plus-Estate Tax}

There has been increasing talk recently of moving toward a broad-based consumption tax system. ${ }^{186}$ Indeed, this is more than just talk; our comprehensive "income" tax is already more-or-less equipoised between an income and a consumption tax model. ${ }^{187}$ If we take into account the increasingly significant payroll tax system, essentially a proportionate consumption tax, ${ }^{188}$ the turn toward consumption taxation appears even more pronounced. This Section presents what is attractive in a consumption ideal while emphasizing that the inchoate spirit of our practices and the best reading of liberalism are both in tension with the typical consumption tax plan that liberal theorists have advocated.

As it turns out, a common recommendation for a comprehensive tax system is a broad-based consumption tax supplemented by a wealth transfer tax. Mill, Kaldor, Rawls, and Andrews have put forth variants of this proposal. ${ }^{189}$ The analysis of Part IV, in emphasizing that an estate tax encourages consumption, casts some doubt on this combination. As Alvin Warren noted in partial response to Andrews' proposal, an estate tax is a tax on at least one form of savings and is thus in some tension with the consumption ideal. ${ }^{190}$ I explore and deepen this criticism, moving it in a different direction than Warren himself intended. ${ }^{191}$

A difficulty with the consumption-plus-estate tax system is that the estate tax turns out to be in tension with many, and possibly all, of the underlying norms of consumption tax theory. As an aside, and to clarify terminology, I note that I am not interested in the question of whether gifts and bequests are,

186. See, e.g., STRENGTHENING AM. COMM'N, supra nole 85. at 91-93

187. McCaffery, Hybrid, supra note 5, at 1152-54.

188. For the comparability of a wage or payroll tax to a consumption or expenditure tax. see Richard a. Musgrave \& Peggy B. Musgrave. Plublic finance in Theory and Practice 22425 (5th ed. 1989) and Warren, Fairness, supra note 157. at 938-41. For a wage or payroll tax to be truly equivalent to a consumption or expenditure tax. there must be no net consumption out of bequests or inheritances, and the tax rate must be constant. If there is no net consumption out of these other sources. then all consumption must be ultimately traccable to carnungs.

189. MILL, supra note 48; NICHOLAS KALDOR. AN EXPENDITLRE TAX (1955). THEORY OF JUSTICE, supra note 19; Andrews. Consumption-Type, supra note 61. at 1172. Andrews. Fatrness, supra note 173. at 957.

190. See Warren, Fairness, supra note 157, at 942.

191. Warren is pnmarily in favor of an income tax and uses his critucism to deflate the perceived logic of Andrews' case for a consumption tax. See id. 
in some sense, "consumption" by the donor. Tax policy analysis has often bogged down in questions such as whether gifts constitute "income," or whether giving constitutes "consumption." 192 Gifts are not consumptive in the technical sense of constituting a private, preclusive, and final use of resources, and yet a donor clearly receives some real, psychic benefit from making gifts, which we are free to call "consumption" if we want. But all of the norms supporting the consumption tax can, and I believe should, be divorced from merely semantic labels. If the consumption tax is attractive on the grounds of efficiency, fairness, or some other reasonable liberal value, then these norms, and not an appeal to prior definitions, ought to inform the debate. Unfortunately, many of these norms remain inchoate, particularly as they relate to fairness. ${ }^{193}$ Nevertheless, three classes of justifications emerge, each of which sits uneasily with an estate tax.

First, supporters of consumption taxation argue that the consumption tax is more "efficient" than the income tax. This efficiency claim, actually more of a utilitarian idea, ${ }^{194}$ consists of two separate strands. The major efficiency claim is that the consumption tax is efficient because it does not distort the savings-consumption decision. More technically, this claim reduces to the argument that there is less total deadweight loss under the consumption tax than under the income tax or any alternative tax regime. Within the welfarist or utilitarian tradition of optimal tax theory, this claim depends more particularly on the compensated elasticity of savings to the tax rate, and also on the general equilibrium effects of the move to a consumption tax on, say, the labor-leisure trade-off. ${ }^{195}$ In performing this delicate analysis, it is important to bear in mind that savings, just as consumption generally, is not a monolithic category. ${ }^{196}$ If bequest savings of the rich have an especially high compensated elasticity, then taxing such savings is especially distortionary. General equilibrium studies have shown large potential welfare gains from a shift to a consumption tax model. ${ }^{197}$ Combining these two points indicates that an estate tax may be a particularly inefficient levy. Contrary to Bentham's and Mill's early intuitions, bequest savings may be the very worst form of savings to tax, at least from a utilitarian, efficiency-

192. See, e.g., SIMONS, supra note 158, at 56-58, 134-36; Aaron \& Galper, supra note 16, at 109-12; Aaron \& Munnell, supra note 6, at 119-21.

193. This point is clearly illustrated in Barbara H. Fried, Fairness and the Consumption Tax, 44 STAN. L. REV. 961, 961-67 (1992).

194. I discuss the distinctions in Edward J. McCaffery. Slouching Towards Equality: Gender Discrimination, Market Efficiency, and Social Change, 103 YALE L.J. 595, 636-43 (1993) [hereinafter McCaffery, Slouching].

195. McCaffery, Hybrid, supra note 5. at 1166, 1170-71.

196. See id. at 1175-79.

197. See, e.g., Fullerton et al., supra note 159, at 4, 22; cf. Auerbach et al., supra notc 159, at 98 ("A transition to a consumption tax is considerably more efficient than a transition to a wage tax; the first generates a large efficiency gain while the second induces an equally large efficiency loss."). BuIt see Feldstein, supra note 89 (suggesting possibility of welfare losses from moving to consumption $\operatorname{tax}$ ). 
oriented, or welfarist perspective.

The minor efficiency claim is that there is market failure leading to an overly low savings rate. While commentators sometimes make this claim as a purely paternalistic point - that consumers are saving too little for their own good, whatever they may think ${ }^{198}$-it fits more easily as an efficiency claim when made as a market failure argument. According to this argument, some cognitive error. such as an inability to make or understand the complex calculations needed to determine an optimal savings strategy, impedes individuals' attempts to act in their own interests. ${ }^{(x)}$ Social responses, such as the mandatory social security system, are then designed to respond to the particular error or failure. This second type of efficiency claim does not bear especially on estate taxation, since almost all such claims refer to life-cycle or precautionary savings and typically involve the lower or middle classes. Nevertheless. the point does underscore the inherent difficulties and costs of looking to any but the wealthy to increase private savings.

A second and distinct argument is that the consumption tax will increase the aggregate level of savings. This argument is not technically an efficiency claim because it does not look to some function of individual preferences. ${ }^{3 \times 1}$ Rather, this second claim is more in the nature of a macrocconomic, meritgood argument: More savings will benefit society regardless of individual preferences at any moment in time. ${ }^{201}$ Consumption tax proponents often make this argument with an eye toward future generations, which are, at least arguably, inadequately cared for under a typically individualistic efficiency norm. But greater amounts of capital affect intra-generational matters as well, as discussed above. More capital would, for example, increase the returns to labor. Most important under a political and interpretive theory of tax, a desire to increase the capital stock appears to be a reasonable. liberal position, which is in fact fueling the movement toward consumption taxation. ${ }^{302}$

198. See Joseph Bankman. Tax Policy and Returement Income Are Prnstun Plan Ant Discrimination Provisions Desirable?. 55 U CHI. L RE 790. 814-21 1988). Deborah M Weuss. Paternalistic Pension Policy: Psychological Evidence and Economic Theon. $58 \mathrm{C}^{\circ}$ CIII L RE 1275. 1275, 1297-1300 (1991). But cf. KOTLIKOFF. WHAT DETERSINES SAVISGs?. supra note 94, al 3 '9 (finding little evidence of insufficient returement savings by elderly Amencans)

199. See, e.g., Richard H. Thaler. Psychology and Savmgs Policies. 84 AW ECoN RLA 186. I84 (1994).

200. To be an efficiency point under the common Kaldor-Hichs formula. the ganns to the "uinners" must be sufficient to compensate the losses of the "losers" and stull leave all parties better oif Ser McCaffery, Slouching. supra note 194, at 636-37 (defining and deseribing Kaldor-Hichs efficiency) To pursue Kaldor-Hicks efficiency in any situation involving future generalions. howeser. We would nave to specify an appropriate discount rate and address the crucial question of whose discount rate should apply. See generally Sen, supra note 83 (discussing difficultues of getung optumal rate of swings under traditional welfarist or democrattc princıples).

201. McCaffery. Hybrid. supra note 5. at $1159-63$

202. See Strengthening Am. Comm'N, supra nole 85. at 83-86. 96-102, sece also H R Con Res 6, supra note 169 (opposing any increase in effective rate of estate tax specifically on grounds that tax harms long-term private savings); William G. Gale \& Robert E. Litan. Saving Our Was Out of the Deficu Dilemma, BrookIngS REV., Fall 1993. at 6 (discussing vanous ways to increase national salings) 
A concern with the aggregate capital stock would look to the total, or uncompensated, elasticity of savings. Such total elasticities of bequest savings, however, may also be high. Thus follows an estimate that a confiscatory estate tax could decrease America's aggregate savings by one-half. ${ }^{203}$ Further, recall that the estate tax may affect the capital stock by distorting ex ante incentive effects and effecting a transfer from wealthy people to poorer persons and the government, both of which have higher propensities to consume. ${ }^{204}$ Bequest savings may once again be the best vehicle to look toward, and the worst to tax, in any effort to increase aggregate capital. Indeed, Stiglitz has recently suggested that it might be optimal to subsidize bequests. ${ }^{205}$

A third set of arguments involves fairness claims, always the most controversial and least articulated in the tax policy lexicon. Perhaps the strongest moral argument for the consumption tax is the one that dates back to Thomas Hobbes, who argued that a consumption tax charges a levy on what a taxpayer removes from the public "pool" for her own, private, preclusive use: "For what reason is there that he which laboureth much, and sparing the fruits of his labour, consumeth little, should be more charged than he that liveth idlely, getteth little, and spendeth all he gets . . ?"206 This statement has a certain cryptic quality, ${ }^{207}$ but the Hobbesian sentiment does seem to capture a commonly held set of beliefs about wealth and consumption. The Hobbesian position is consistent with a general aversion to excessive private consumption, found elsewhere in Hobbes' writings and throughout Western (and other) religious traditions, ${ }^{208}$ and picked up, centuries later, by Thorstein Veblen in his classic work, The Theory of the Leisure Class. ${ }^{209}$ The idea also resonates with liberal egalitarian, intra-generational norms. Rawls seems to have accepted its logic in A Theory of Justice, when he notes that a "proportional expenditure

203. See Kotlikoff, What Determines SaVings?, supra note 94, at 41.

204. See Stiglitz, supra note 86 , at S138-45.

205. Stiglitz's reasoning here is based more on the nature of the social welfare function. See Joseph E. Stiglitz, Pareto Efficient and Optimal Taxation and the New Welfare Economics, in 2 HANDBOOK OF PuBLIC ECONOMICS 991, 1035 (Alan J. Auerbach \& Martin Feldstein eds., 1985 \& 1987) ("Since giving increases the utility both of the giver and the receiver, it is doubly blessed in our social welfare function, and the government will seek to encourage it, through a bequest subsidy.") (emphasis removed).

206. ThOMAS HoBbes, LeviaTHan 238-39 (Richard Tuck ed., Cambridgc Univ. Press 1991) (1651). The quote paradoxically continues: "seeing the one has no more protection from the Common-wealth, [than] the other?", indicating that Hobbes was thinking of a benefits principle of taxation. Id.: see Richard Musgrave, A Brief History of Fiscal Doctrine, in 1 HANDBOOK OF PUBLIC ECONOMICS 1, supra note 205, at 16-18. Hobbes may even have been thinking of a lump-sum, head tax. I believe that the normative position attributed to Hobbes is appealing, whether or not it is in fact consistent with Hobbes' own thoughts on the subject.

207. See. e.g., Fried, supra note 193. at 962-63 (criticizing Hobbesian or "foundational argument" in favor of consumption taxation).

208. See R.H. TAwneY, Religion AND the RISE of CAPITAlism 248 (Peter Smith ed., 1962); McCaffery, Hybrid, supra note 5, at $1162-63$ (citing numerous sources). See generally MAX WEBER, TIE PROTESTANT ETHIC AND THE SPIRIT OF CAPITALISM (1958) (discussing connection between capital accumulation and Protestantism).

209. Thorstein Veblen, The Theory of the Leisure Class (B.W. Huebsch ed., 1918) (1899). 
tax may be part of the best tax scheme."210 Rawls continues:

For one thing, it is preferable to an income tax (of any kind) at the level of common sense precepts of justice, since it imposes a levy according to how much a person takes out of the common store of goods and not according to how much he contributes (assuming here that income is fairly earned). ${ }^{211}$

Rawls cites Kaldor, not Hobbes, in support of this proposition."12 Kaldor himself thought that "spending power" was a more meaningful measure of normative taxability than income, for many of the same reasons, although he elsewhere notes problems stemming from wealth possession alone. ${ }^{13}$ But if liberals ought to look to private consumption, the estate tax's inducement of greater consumption, specifically by the rich, may be illiberal.

There is indeed a strong appeal to the position that use is a more important liberal concern than possession, which I take up again shortly. For now, my more limited claim is that if a concern about monitoring consumption indeed underlies the moral appeal of the broad-based consumption tax, tacking on an estate tax undercuts and counteracts that concern. If we have some moral or political reason for disliking private, preclusive consumption, perhaps particularly the excessive, conspicuous consumption of the very wealthy, it seems odd to be encouraging such consumption with an estate tax. The estate tax may increase inequality of consumption, presumably the precise sociat space of most concern to consumption tax advocates, while decreasing the productive contributions of work and savings.

Of course, it is possible that even the conspicuous, extravagant consumption of those whom we view as having earned their wealth is less offensive than any consumption of unearned wealth among their heirs; this idea reflects the liberal egalitarian's sharp separation of intra- from intergenerational concerns. This argument, however, is a more difficult road to travel than it at first might appear, since it depends, among other things, on the normative propriety of market outcomes. Recall Rawls' proviso in $A$ Theory

210. THEORY OF JUSTICE, supra note 19, at 278 (c)ung KALDOR, supra note 189)

211. Id.

212. Id. at $278 \mathrm{n} .17$. Interestingly, Rawis gives Hobbes credit for this pount in his later manuscnpt

[I]ncome taxation might be avoided altogether and a proportional expenditure tax adopted

instead, that is, a tax on consumption at a constant marginal rate. People would be taxed according to how much they use of the goods and services produced and not according to how much they contribute (an idea that goes back to Hobbes).

Justice as Fairness, supra note 29. at 130-31. Rawls appears to have an ambivalent view of his work"s relation to Hobbes, who also adhered, broadly speaking. to a liberal contractanan tradition For an interesting discussion of Hobbes and Rawls and some matters in between, see David Gauther. Bemeen Hobbes and Rawls, in Rationality. JUSTICE AND THE SOCIAL. CONTRACT: THENES Frow HoRals BY AGREEMENT 24 (David Gauthier \& Roben Sugden eds.. 1993)

213. Cf. Duff, supra note 2, at 15-16 \& n.67 (noting Kaldor's view that mere possesston of wealth confers special ability to pay tax, but arguing that such taxable capacity does not justify inhentance tax) 
of Justice, qualifying his support for a proportionate consumption tax on the fact that income be "fairly earned." 214 If lifetime income is not fairly earned-if, for example, market outcomes are suspect-then there are intragenerational inequalities that are not necessarily caused by inter-generational transmissions. As the third liberal argument in Part II suggested, this change in assumptions from ideal theory puts a good many issues on the table, including the effects of wealth transfer taxation on productivity, the capital stock, and intra-generational consumption. It now becomes possible that inequality in use is more offensive, even to prior liberal values such as the fair equality of opportunity, than is inequality in possession, as I discuss below.

To press an even stronger argument, earnings may be the wrong variable on which to focus. As stated in the fourth argument from Part II, even under ideal or just conditions, a consumption-without-estate tax may still be the best liberal tax scheme because it consistently looks to use, not earnings. Rawls believes it ethically appropriate to tax use, not "contributions," by which latter term we ought to include, as Rawls' language clearly does, both work and savings. (Commentators often seem to infer that "contributions to the common store" refer only to savings, but there can be no savings without antecedent work.) ${ }^{215}$ Hobbes' language echoes the thought: Hobbes means to reward (or not to punish) the industrious and the thrifty. These ideas suggest that use is a more compelling concern than earnings. We can go even further and make yet a stronger point. Under just transactional systems, earnings represent the preferences of autonomous others. Thus, a liberal political society wants Mr. Perot or Michael Milken or Madonna to earn their millions, because they are doing what society wants them to do; social preferences are setting their salaries. To meet any liberal concerns with unfair earnings, we set up social rules over transactional systems: for example, laws against monopoly, discrimination, fraud, or coercion. Earnings would then be fair precisely because they would respond fairly to individual preferences. If we then create incentives leading away from work, such as via the estate tax, we deny third

214. THEORY OF JUSTICE, supra note 19, at 278 (parenthetical proviso that income be "fairly earned"); see also Joel Feinberg, Rawls and lntuitionism, in READING RAWLs 108, 116-24 (Norman Daniels ed., 1975) (discussing problems of "non-ideal theory" vis-à-vis Rawlsian theory); cf. DWORKIN, MATTER OF PRINCIPLE, supra note 20. at 205-10 (questioning fairness of market outcomes); Graetz, supra note 2, at 275-78 (questioning propriety of market outcomes, using example of Olivia NewtonJohn). Note that I am not making the argument, rightly criticized in Haslett, supra note 3, at 141-42, that because some inequalities will persist, none should be attacked. Rather, my argument is a more particular one, suggesting the need for a more comprehensive focus on the intra-generational use of resources.

215. Fried refers to this "common pool" argument as the Hobbesian or "foundational" one and puts It aside to concentrate her critique on what I am calling the subjectivist, or individualistic grounds of the consumption tax's fairness claims. Fried, supra note 193, at 962-63. Fried does specify two criticisms of the foundational argument: its ignorance of the psychic yield of possession and the power that investment decisions bring. Id. I refer to these as possession qua actual or potential use, and believe that a properly devised tax system can respond to them. Fried also notes that "[t]he argument raises a number of other problems as well, and an adequate treatment of it has yet to be undertaken." $I d$. at 963 . On one level, I intend this Article to take a step in that direction. 
parties a benefit for which they are willing to pay. Meanwhile, the putative millionaire can simply substitute leisure of equivalent psychic value for productive work effort.

Use presents a different, indeed opposite, paradigm from work or carnings alone. It is use that takes away from others-from third parties or from the "common store"-and diverts resources to private preferences. Use represents an imposition by the individual on the collective. Those who do not want to interfere with earnings under just systems may indeed care about use and be willing to interfere with it. At least up to the point where envy becomes an issue, ${ }^{216}$ the political liberal state may reasonably cede to this concern. In T.M. Scanlon's terms, society may take an objective stance vis-à-vis use, at least at certain high quanta of expenditure, under which we can (and do) make moral judgments as to the urgency of wants. ${ }^{21}$ : Thus, liberal society may well be glad that Mr. Perot did whatever he did to earn his billions (assuming again with Rawls that income is fairly earned), but still consider his ability to make rapid use of his fortune both relatively unimportant or nonurgent, and even dangerous to prior liberties. In both cases-approving carnings and disapproving excessive use-society is being objective and political, through and through.

Of course, there are questions and problems. If parties capable of high earnings insist on spending all of their earnings, society faces a choice between the good of work effort and the bad of excessive private, preclusive use; society must draw lines. All practical tax systems come down to some more or less arbitrary choices. But if an individual is willing to work and save and consume her high earnings prudently over many years, or even pass them on to her heirs, then society can avoid passing judgment on her earnings per se. We can, in short, minimize and alter the class of people as to whom we must make a trade-off between productivity (a social good) and inequality (a social bad); we can burden only the decadent consumers or spendthrifts among the most productive. Those productive parties not spending their wealth irresponsibly are serving the public good and need not be overly taxed.

The basic argument runs as follows: Once we abandon theories of merit or desert and adopt instead a more nuanced, political, and objective theory of distributive justice-one that systematically incorporates questions of incentive effects and social mores-then the simple mandate for steep wealth transfer tax systems, specifically on the grounds that inherited wealth is not "earned," wanes or even disappears. We can arrive at this point through two different, though interestingly convergent, routes. First. we can conclude that "earnings" are not prima facie just in a nonideal, imperfect world. Second, we can

216. See. e.g., THEORY OF JUSTICE. supra note 19, at 530-41 (discussing en! in a liberal stale,. Young, supra note 178 (discussing envy in a just liberal stite)

217. Scanlon, supra note 14. at 660-61. 
conclude that it does not matter whether "earnings" are just as a matter of ideal theory; the justice of earnings is not relevant to the justice of use. Even if earnings are fairly secured, liberal society has objective, political reasons to like earnings while disliking at least large-scale use.

There are fairness arguments for the consumption tax other than the various "common store" arguments. Perhaps the most common is the horizontal equity point that compares the saver to the consumer and asks why the former should be "double taxed." 18 As Warren noted, however, tacking on the estate tax only adds another point of comparison: We are "penalizing" the bequest saver relative to both the lifetime saver and consumer. ${ }^{219}$ It is far from clear that this choice is sensible. Whereas Warren intended his comments as a critique of Andrews' reasoning in support of the consumption tax, we can and shall take the comments the other way: as a critique of Andrews', and by extension of consumption tax theory's, embrace of a transfer tax.

Looking at the donor, as Warren's analysis does, can help us to focus on some interesting aspects of the wealth transfer tax puzzle. Consider two individuals, Mr. Spendthrift and Ms. Thrifty. ${ }^{220}$ Suppose Mr. Spendthrift receives a small fortune of $\$ 2$ million early in his career, when he is twentyfive years old, and imagine that he acquired it through one of the following scenarios: by earning it in the labor market; by making it in the financial market; by winning the lottery; or by inheriting it. Mr. Spendthrift spends most of his remaining days traveling around the world, eating at the best restaurants and drinking the finest wines. At some point he even purchases a private annuity and spends every cent from each year's payment, so that he deliberately leaves nothing to his children.

Now suppose that Ms. Thrifty also receives $\$ 2$ million at age twenty-five. To test intuitions, imagine that she receives it on account of the same reason Mr. Spendthrift acquired his. (The point of this mental exercise is to show that the justice of earnings is logically and ethically distinct from the justice of use.) Ms. Thrifty invests her money wisely and continues to work and earn and save more money throughout her life. She lives simply but well, teaching her children the importance of saving for the future, of working for its own sake and for what work can provide to others, and of not living ostentatiously. When she dies, she bequeaths sizable sums to her children, who are then well into the middle stages of their lives, established in their careers, and deeply engaged in raising their own children with the same simple virtues learned

218. See, e.g., MLL, supra note 48, at 815-16; Andrews, Consumption-Type, supra note 61, at 1167-68. But cf. KALDOR, supra note 189, at 79-91 (discussing and criticizing Mill's "double tax" criticism); Richard A. Musgrave. The TheORY OF Public FINANCE 161-63 (1959) (same).

219. See Warren, Fairness, supra note 157, at 942.

220. The next few paragraphs borrow from a work in progress, The Political Liberal Case Against The Estate Tax, in which I am exploring the more purely philosophical dimensions of the issues raised here. 
from their mother.

The current estate tax applies only to Ms. Thrifty and her family. And it is a harsh tax, taking away up to half of the Thrifty's wealth. Mr. Spendthrift and Ms. Thrifty are equal in some morally compelling sense, since they each face, ex ante, the same opportunity set (and, by hypothesis, each carned their wealth in the same way). Mr. Spendthrift, however, chooses a maximum consumption and leisure route, while Ms. Thrifty does not. In choosing to tax only Ms. Thrifty, the tax system seems to have adopted an ex post perspective: It is looking backwards from the grave. Yet unlike other situations where such an after-the-fact perspective seems morally appropriate-for example, in compensating accident victims even if they had an ex ante opportunity to insure but did not-the differing ex post statuses of Ms. Thrifty and Mr. Spendthrift do not, in any compelling sense, turn on "luck." The different statuses result from conscious choices and come to pass, again unlike the accident or some other windfall setting. without ever changing the equivalence of the opportunity sets that both individuals face. We have posited that, throughout their lives, Ms. Thrifty and Mr. Spendthrift faced exactly the same choices, so that, in an important and meaningful sense, the value of $\mathrm{Mr}$. Spendthrift's consumption equals the value of Ms. Thrifty's savings and consumption combined.

Of course, Ms. Thrifty's children have an advantage, in ierms of their ex ante opportunities, over Mr. Spendthrift's children. Herein lies one of the puzzles of estate taxation: One person's "luck" in receiving inherited wealth typically relates to another person's, the benefactor's, conscious, non-lucky decisions regarding work, saving, and so forth. ${ }^{221}$ By a natural process of backward induction, the decision to confiscate the donee's seemingly lucky windfall will affect the lifetime choices of the donor. We get a very different look at issues of estate taxation depending solely on our choice of analytical framework. That is, our view depends on whether we look at the estate tax from the donor's or the donee's perspective, ex ante or ex post. Analogously, our thoughts may change depending on the range of alternatives that we have

221. See generally Ripstein, supra note 183 Ripstein's excellent essa) draws altention to the irreducibly political nature of our concepts of "luch" and "responstbility " Rupstein tends to tocus on bad luck, asking where the onus of such luch should reside He how, thst the question of trante or perspective is vital. If an accident has occursed-a hammer 1 atm using falls on sour head, wy - It matters on whom we focus. To say that it is not my fault is to say that it is your bad luch, to sis that 1 (or society at large) should pay is to say that it is my (or society s) bad luch. not yours if He ve" the estate tax as implicating the question of good luch. we then have a parallel sel of concems It we tocus on the donee. we may see an unacceptable appropration of good luch But to deny that gexd luith to the donee is to put it somewhere. Lihe bad luck. good luch cannot just disuppear As II is. "we do little under the current inefficacious estate tax to diver the good luch at all 1 din arguing further that, under a truly confiscatory tax. much of the good luck is apt to mure bach wards to the putalise fonor In contrast, the progressive consumption-without-estate tax solution is an attempt to allow the donee wo hold her good luck in a fiduciary capacity for the body politic and thus, in effect. 10 share a Once again, perthaps paradoxically, a more thoroughgoing skeptucism about marhet outcomes. and a concomitanty more political treatment of wealth, might lead aganst. not in faror ot. chtate tatstion 
in mind, which is a central theme of this Part. There are ways to address the advantages to Ms. Thrifty's children, for example, without unduly burdening Ms. Thrifty herself.

The estate tax works like the opposite of "sin" taxes on goods such as alcohol and cigarettes, which are (also) not designed to raise revenue, but to control behavior or to curtail certain vices. The estate tax is quite possibly an anti-sin tax, or, equivalently, a virtue tax. The estate tax is a tax on work and savings, on thrift, and on altruism. Now, the type of horizontal equity analysis embedded in the Thrifty-Spendthrift discussion is not necessarily decisive; indeed, this discussion is precisely the type of "metaphysics" that a political liberal theory of tax aims to avoid. ${ }^{222}$ The more important question of why savers and spenders ought to be considered horizontal equals vel non collapses back into the previously discussed concerns about liberal values: efficiency, distributive justice, virtue, and so on. But like other pair-wise comparisons, the Thrifty-Spendthrift example is best used to prod our moral intuitions. Here, the example illustrates once again that society may want to take an objective ethical stance in favor of thrift over consumption, or, more accurately, a stance against disfavoring thrift.

The bottom line of these discussions is that, while a consumption tax is attractive on liberal grounds and is supported by our practices' shift toward it, adding any transfer tax is highly questionable under the three broad sets of claims supporting the consumption tax model. The first two economic arguments clearly seem to counsel against tacking on an estate tax. Various fairness claims also counsel against the tax. A wealth transfer tax induces or rewards behavior that the consumption tax is intended to discourage: consumption, leisure, and inter vivos giving. It is thus hard to get to the consumption-plus-estate tax position from a consideration of consumption tax norms alone.

Perhaps for this reason, liberal advocates of a consumption plus-transfertax model generally proceed from a different direction. They accept the consumption tax, for one or another of the above reasons, despite what they perceive as its major vice: its tolerance of large stores of private, unevenly distributed wealth. The estate tax is intended to be an antidote to the consumption tax, since it supposedly reaches the lifetime accumulations of wealth that the consumption tax explicitly condones. Under this view, the estate tax is a means of "leveling the playing field" to preserve meaningful and prior notions of equality, quite apart from concerns about efficiency or wealth maximization. Rawls, Kaldor, Andrews, and Mill call for some type of wealth transfer taxation to respond to real or perceived criticisms of their consumption

222. See generally Louis Kaplow, Horizontal Equity: Measures in Search of a Principle, 42 NAT'L TAX J. 139 (1989) (criticizing horizontal equity as unnecessary and even countcrproductive normative constraint). But cf. Richard A. Musgrave, Horizontal Equity, Once More, 43 NAT'L TAX J. 113 (1990) (responding to Kaplow). 
tax proposals. ${ }^{223}$

There are, however, problems with this particular compromise. The consumption-plus-estate tax model becomes deeply schizophrenic, even oxymoronic; we are "saving" the consumption tax model from its critics by undermining exactly those reasons why we should have supported it in the first place. Under a political and interpretive theory of tax, the real-world fact that we do not seem to want any truly effective wealth transfer tax is also relevant. The more we move away from individualistic, subjective, and even metaphysical notions of earnings, entitlements, and desert, the more we begin to see the necessity or wisdom of taking objective stands, which favor work and savings and disfavor only, or at least especially. the excessive private preclusive use of resources. This reasoning suggests that progressivity, and not transfer taxation, is the most compelling answer to the liberal's sense of unease with wealth accumulation under a consumption ideal. A progressive consumption-without-estate tax-my ultimate proposal, to which I now turn-not incidentally changes the very meaning, and hence the risks and dangers, of the private possession of wealth. Getting there via strictly political arguments also helps to inform the precise shape of the preferred liberal tax system.

\section{A Progressive Consumption-Without-Estate Tax}

We have made our way, finally. to a practical proposal that addresses liberal egalitarian concerns without including any estate tax al all. We have seen that the status quo. with its flawed income-plus-estate tax, is not working in theory or in practice. We have seen that there is much that is popular and normatively attractive in consumption lax theory, but that what is most appealing in this alternative tax scheme is in tension with any wealth transter tax. We have seen that our practices have in fact resisted any meaningful estate tax. Finally, we have seen that an objective. political, liberal perspective approves of work and savings, while only or at least especially questioning excessive private use. All of these ideas lead to my fifth and tinal liberal argument against an estate tax: the desirability of a progressive consumptionwithout-estate tax.

The plan derives in part from economic thinking, which has shown us that any real-world scheme of wealth transfer taxation is apt to encourage inter vivos gifts, or to discourage work effort and capital accumulation among the wealthy, or to do both. The answer also draws in part from an exploration of the intuitions lying behind advocacy of the consumption tax model. I presume

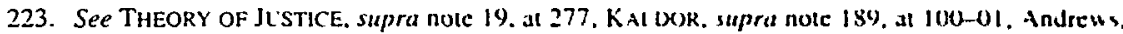
Consumption-Type, supra note 61. at 1172. Andreus. Futriess, supra nole 173. at 957. A111. supra note 48 , at $811-12$. 
that a basic intuition, from Hobbes on down, has been that the use of wealth, and not its mere possession, is what really concerns liberal society. This position is the core of what I am taking to be the consumption tax's principal fairness claim. ${ }^{224}$ Indeed, if possession alone were a concern, there would be little reason to prefer a consumption over an income tax, as we have seen above. It is time to explore more deeply the reasons for being more concerned with the use of wealth than with its possession, to see if this inchoate idea is reasonable.

On the one hand, use of wealth represents the type of charge against common resources that angered Hobbes and concerned Rawls. Use can also be conspicuous, in Veblen's sense, inciting envy (or worse). It reflects spending power, in Kaldor's sense. It can corrupt political processes, as in the Perot example, and thereby interfere with the exercise of prior liberties. Excessive use can normatively distort the price system, an effect that can be especially important: It appears, for example, that certain basic commodities are more expensive in richer countries, both absolutely and relatively, because price levels reflect the consumption of the wealthy, whose expenditure decisions draw resources toward certain luxurious goods. ${ }^{225} \mathrm{~A}$ related reason why poverty can exist or even flourish in developed countries is the increased costs of simply keeping up with the consumption of one's neighbor-of "appearing in public without shame," as Adam Smith once put it. ${ }^{226}$ It is also interesting to note that, left more or less on their own, people seem to reach a consumption satiation level, as evidenced by the fact that the elderly apparently continue to save, not dissave, beyond life-cycle needs. ${ }^{227}$ This fact of satiation indicates that taxing excessive consumption may not run counter to ordinary behavior as much as taxing bequests.

On the other hand, private savings have some distinct virtues. Private

224. See, e.g., KALDOR, supra note 189, at 24-37; Andrews, Consumption-Type, supra notc 61, at 1114-17. But cf. Mark G. Kelman, Personal Deductions Revisited: Why They Fit Poorly in an "Ileal" Income Tax and Why They Fit Worse in a Far from Ideal World, 3I STAN. L. REv. 831, 833-35 (1979) (arguing that use is irrelevant to tax law).

225. See SEN, supra note 136, at 114-16 \& n.34. Frances Williams argues that because it is financially unattractive to service the needs of those who consume relatively little, the goods and services that the poor purchase are more expensive in an absolute sense. See Frances Williams, Conclusion to Why THE POOR PAY MORE 235, 235 (Frances Williams ed., 1977).

226. See SEN, supra note 136, at 115 (discussing 2 SMITH, supra note 92, at 399). Peter Townsend has observed that "Iploverty can be defined objectively and applied consistently only in terms of the concept of relative deprivation." PETER TOWNSEND, POVERTY IN THE UNITED KINGDOM 31 (1979); sec also id. at 50 ("Needs arise by virtue of the kind of society to which individuals belong. Society imposes expectations, through its occupational, educational, economic and other systems, and it also creates wants, through its organization and customs."). See generally Richard H. McAdams, Relative Preferences, 102 YALE L.J. 1 (1992) (discussing problems of negative relative preferences such as competitive consumption).

227. See KotlikofF, What Determines SAVINGS?, supra note 94, at 23; Kotlikoff, Intergenerational Transfers, supra note 94, at 48-51. But see Hurd, supra note 94, at 298, 306 (concluding from empirical data that, contrary to most cross-section studics, the elderly dissave after retirement, so that there is no evidence of bequest motive). 
savings result from possession without use. which in turn implies productive work effort. As Keynes long ago noted, private wealth can undergird social, macroeconomic progress. ${ }^{228}$ Private wealth can also counterbalance government power, and private investment decisions are typically more efficient than public ones. Interestingly, in discussing the relative priority of the difference principle as compared to the fair-equality-of-opportunity principle (recall that the latter is lexically prior), Rawls looks directly at the Keynesian argument in A Theory of Justice. ${ }^{229}$ Keynes had argued that the frugality of turn-of-the-century British capitalists was critical to England's social advances. Rawls seems to agree that capital per se inures largely to the benefit of the working classes, although he continues to imply that questions of savings are largely inter-generational ones. ${ }^{250}$ But Rawls next notes that "there are more efficient and just ways of raising the level of well-being and culture than that Keynes describes." ${ }^{231}$ without specifying what these ways are. Rawls concludes his discussion of Keynes by asserting that "[i]t is only in special circumstances, including the frugality of the capitalist class as opposed to the self-indulgence of the aristocracy, that a society should obtain investment funds by endowing the rich with more than they feel they can decently spend on themselves." 232

To be blunt, Rawls may be wrong here. Repealing the estate tax may in fact be one of the most efficient and even just ways to increase capital, as I have argued throughout this Article. The very presence of the estate tax induces certain unjust behavior, such as large inter vivos gifts and large-scale consumption by the rich. More to the point, what Rawls fails to see in the quoted passage is precisely the possibility that we can use the tax system to ensure, or at least to regulate, the "frugality of the capitalist class." The state can do what individuals otherwise might not, of their own accord: guarantee that only the frugal get to keep their large amounts of private wealth. Rawls' blind spot here no doubt has something to do with the fact that he already advanced, twenty pages prior, his own proportionate consumption-plus-transfer tax proposal, following in the footsteps of Hobbes, Mill, and Kaldor. Rawls also seems to believe that the point of the basic general tax system is solely to raise revenues, ${ }^{233}$ thereby ignoring the large and inevitable behavioral distortions of modern tax systems and, as important, missing the unique possibility provided by tax systems to implement objective social values over the urgency of wants. In any event, the curtailment of self-indulgence without

228. See John MaYnard Keynes. The Econonic Conseot thas of Tht Place 18-22 11920)

229. THEORY OF JUSTICE. supra note 19. at 298-301

230. Id. at $287-88$.

231. Id. at 299.

232. Id. (emphasıs added).

233. Id. at 278 ("The second part of the distribution branch is a seheme of taxation to rase the revenues that justice requires."). 
a general burden on frugality or accumulation is, of course, exactly what the progressive consumption-without-estate tax aims to do. It aims to reward, to encourage, or at least not to deter the frugality of the capitalist class, and only to penalize or discourage the self-indulgence of the aristocracy. A progressive consumption-without-estate tax reverses the effect of current law: It penalizes Mr. Spendthrift, and not Ms. Thrifty. Separating consumption from possession is the essence of this move.

Recall the Stiglitz-Smith conjecture that the estate tax effects a transfer from those with a greater propensity to save to those with a greater propensity to consume, thereby lowering the capital stock. ${ }^{234}$ An initial instinct may be that this loss is an unavoidable feature of all redistribution; all ethically appropriate redistributions take from the rich and give to the poor. But this thinking is not true once we distinguish between use and possession. Taxing the use of wealth is a way of allowing the most efficient savers to hold on to their capital, while at the same time serving many, if not all, liberal egalitarian ends. Private savings may be the most efficient way to increase the capital stock, as Keynes saw clearly enough, and an increased capital stock will have progressive effects, intra- as well as inter-generationally. Moving toward a progressive consumption-without-estate tax may be the "best" way-the most fair and efficient-to increase private savings while still monitoring private use. In any event, under a political-interpretive theory of tax, it is not necessary to prove, decisively, the optimality of a practical program. Rather, it is sufficient to show that the program is at least implicit in our practices and reasonable from a liberal point of view. The progressive consumption-withoutestate tax satisfies both prongs of this test.

To be sure, two rather large sets of problems remain. First, there appear to be equitable and political issues involving the concentration of power accompanying private wealth and investment decisions, and some benefits flow from possession alone. ${ }^{235}$ Second, as the liberal egalitarian case reminds us, the use of wealth by those deemed to have "earned" it may not be as offensive as any use of such wealth made by subsequent generations, although skepticism over the relevance or meaning of "earnings" weakens this point, perhaps fatally. These objections are common and well founded; the key response is that we do not need an estate tax to deal with either issue.

As to the first point, a combination of progressive rates and investment regulation under a nominal "consumption" tax can check the liberal dangers of possession alone. A progressive consumption tax changes the very meaning and hence the risks and dangers of private "possession." Many, and maybe all, of the normative problems with the private possession of wealth turn out to relate to possession qua actual or potential use. The Perot example is once

234. See supra notes 104-05 and accompanying text.

235. See, e.g., Fried, supra note 193, at 962 n.7 \& 963 n.8 and citations therein. 
again helpful. The actual use, or even the mere threat of use, of Mr. Perot's billions poses a vivid example of what Rawls refers to as "power detrimental to the fair value of political liberty and fair equality of opportunity."2to A progressive consumption-without-estate tax, however, checks precisely this kind of use, and even the threat of it. It restrains $\mathrm{Mr}$. Perot from being able to spend his billions quickly or in large units. without necessarily discouraging Mr. Perot from earning ab initio. On the other hand, one might consume or exercise power directly through investment; this is possession qua use. Think, for example. of William Randolph Hearst buying up newspapers. But we can readily enough deal with that problem by compelling the private saver to save in certain forms-a blind trust is a limiting example, but any qualified form of savings accounts will do-in order to get the benefits of the nontaxation of savings. ${ }^{237}$ Such vehicles can preserve the efficiency of decentralized decisions while checking abuse, much as the loose form of government oversight of the current pension and charitable activity sectors now does. In both of these responses, the progressive consumption-without-estate tax plan aims to make literal the common pool metaphor of Hobbes and Rawls. Possession is no longer narrowly "private."

As to the second problem, of inheritance and inequality, we can deal with the issue of use by later generations through modifications in the consumption tax's rate structure. Society may actually have a greater concern with the inequities of inherited wealth. I have not denied that there might be such a concern; I have simply emphasized that a crude attempt to choke off intergenerational transfers may: (1) interfere with important intra-generational norms, in part by its dependence on a naive division between intra- and intergenerational spheres of activity; and (2) clash with settled and normatively appropriate practices and beliefs evincing more of a concern with the use than with the mere possession of wealth. Indeed, we can see that the use-possession distinction extends down through the generations. While society no doubt has some concerns over the possession of unearned wealth by later generations, and such concerns may be greater than those over possession alone at the earlier generation, the concern vis-à-vis the later generation may once again be even greater when it comes to use. Society may have some worry over imprudent investment decisions by heirs, say, but we can again deal with this point by regulating the favorable consumption tax treatment. Moreover, it is not clear that the alternative uses of that capital-now understood to be either

236. THEORY OF JUSTICE, supra nole 19, al 277.

237. See, e.g., Willam A. Klein. Timing in Personal Taxation. 6 J. Ligal. ST D $\$ 61,480$ (1977) ("Since the government has forgone current taxation of income " seems plaun that the government has a direct financial interest in how such funds are managed. "). The current returement system in Chile works along illustrative lines; individuals are compelled to sase from among a menu of government-approved accounts. See James Brooke. Quet Revolutuon tn Latun Pensions, XY Y TIWES. Sept 10, 1994, § 1, at 37 (Late Edition). 
investment decisions by the government or increased consumption by the prior generation - are any better. In contrast, society may have a much heightened concern with the decadent use of wealth by the later generation, and here may decisively prefer the alternatives of any other use. Yet under current law, society places no burden on the act of consumption by an heir; we exert no control whatsoever over how or when heirs spend their wealth. Under a progressive consumption-without-estate tax, this hands-off attitude would change, and we can change it even more fundamentally with a separate rate schedule on spending out of inherited wealth.

Details as to the precise rate schedule will of course need to be worked out, and they may require difficult and ultimately somewhat arbitrary decisions. For now, I seek mainly to illustrate where a consistent liberal egalitarian focus on use, implicit in consumption tax theory, might naturally lead: to a progressive consumption-without-estate tax. Such a structure responds to concerns over possession alone by changing our conception of what "possession" means. This tax plan is also what our practices seem to be suggesting; we can go a long way toward resolving many problems by making the inchoate themes more conscious and deliberate. Let us take now a closer look at some specifics.

\section{A Modest Proposal}

The above discussion has led to a specific comprehensive tax reform proposal: a progressive consumption-without-estate tax, possibly supplemented by a separate and higher rate structure on spending out of gifts or bequests, and a regulatory regime loosely monitoring nominally private investment decisions. This Subsection fleshes out a few details. I begin by clarifying a semantic point: This tax proposal is actually a step toward the wealth-based norms of the income tax; it is a hybrid tax, situated between an income and a consumption model. Typical consumption tax theory has rested on a subjectivist or individualistic basis, explaining the invocation of concepts such as "earnings," horizontal equity comparisons between savers and spenders, and so forth. A political liberal proposal, in contrast, rejects this logic, either because of its inapplicability in a nonideal setting or on ideal but objective ethical grounds. The tax proposal follows consistently from the idea that liberal society likes work and savings, but has liberal suspicions over excessive consumption.

To see the point that a progressive consumption tax is not really a pure consumption tax, it helps to review a few doctrinal features of the income versus consumption tax debate. Typical consumption tax theory, as advanced by Mill, Rawls, and others, calls for flat-rate taxes. ${ }^{238}$ The reason is that 
otherwise, money saved in a low tax rate period may be taxed later at higher rates, thereby penalizing the saver vis-à-vis the consumer: an outcome precisely opposite to a central individualistic theme in consumption tax theory. To assure that the income from capital bears no tax, therefore, consumption tax advocates could adopt the "prepayment," or yield-exempt, model of the consumption tax: Tax wages as earned, and thereafter ignore all capital and its earnings. ${ }^{239}$ This form of consumption taxation would leave any burden of progressivity to fall exclusively on wages. ${ }^{2+0}$ Such a progressive prepayment model, however, would also violate some of the consumption tax's underlying individualistic intuitions, because it would penalize those taxpayers with incomes spread unevenly throughout their lifetimes. Consider, for example, the case of a law student who sacrifices earnings potential in her youth in part to earn high wages over a concentrated period later in life. A progressive prepayment model penalizes this individual, and so implicales patterns of human capital accumulation and risk taking that do not necessarily differ in any normatively compelling manner from more traditional forms of savings. ${ }^{241}$ These objections might lead to income averaging, ${ }^{2+2}$ but at some

Fairness, supra note 157. at 944-16. But of. Andrews. Consumptuon-Tipe. supra note 61. at 1175-77. Andrews, Fairness, supra note 173. at 954-56 (arguing for progressive consumption (ax). Warren. Consumption Tax, supra note 157. at 1083 ("Penonal progression is a crucial aspect of the case for such an expenditure tax . . . .). See generally BLLEPRINTS FOR BAstC TAX RErokM 122-25 (David F Bradford et al. eds., 2d ed. rev. 1984) (hereinafter BLL EPRINTS] (discussing progressivily of cash flow consumption tax); Fullerton et al.. supra note 197 (modeling effects of progressive consumption tax) Indeed, the general form of the proposal put forth in the text-for a progressive consumption-withoutestate tax-seems to be in accord with the pnmary consumption tax model adianced in Blueprints The basic Blueprints model is for a cash flow tax with progressise marginal rates and with "transfers deductible to the donor and included in the tax base of the recipient." Id. at 125 Blurprints only mentions this non-transfer tax aspect briefy, however, and quichly follows up on it with the possibility of retaining "the estate and gift tax as the principal instrument for altering the distribution of wealth" Id. For reasons chronicled at length in the text. I belicve that this qualification would swallow up the normative impetus leading to it. Nonetheless, the strong simularitues between the Blueprints proposal and my own, derived independently, are a positive indication of the attractiseness of the general approach

239. The literature has long noted the substantal equivalence of two means of implementing a consumption-type tax. One is the prepayment or yicld-exempt method, which taxes wealth as earned and thereafter ignores the yield: consider the case of buying a consumer durable, such as a house or car The second is the qualified account or cash flow method, which postpones the single monent of tax unul the time of conversion of wealth into consumption. thinh of the was qualified pension plans work These methods are equivalent if: (a) the tax rate remains constant. and (b) the existence of iniramarginal investment returns-windfalls-is proportional to the net nomunal amounts invested. See Mficharl $J$ Graetz, Expenditure Tax Design, in WHAT SHOLLD BE TAAl:D INCONE OR EXPENOTT RE? 161. 172-75 (Joseph A. Pechman ed., 1980); McCaffery. Hybrid. supra note 5, at 1151 n.24. Jeff Sirnad. Taxation of Income from Capual: A Theorencal Reappraisal. 37 STAV L. REV 1023. 1035-38, 1068-72 (1985)

240. See Warren, Fairness, supra note 157. at 940 ("[T|he consumption ideal thus effectuvely exempts all property income from taxation while including all income from personal senices")

241. That is, the law student who takes time off from her career path and spends tuttion money on schooling is "saving" in an important sense: She is investung the tultion money and the forgone earnings in herself. The "asset" that this savings generates is increased human capital. and the monetized worth of that capital is manifested in a higher level of earnings after the education Taxing these eamings at a higher rate, under a progressive tax system. penalizes the person who has made the investment in human capital vis-à-vis the steady. lower-level earner All of these conecrns are diffesent from the observation, whtch is also true, that the present income tax tends to treat human capital under a cash flow, consumption model, in contrast to the Haig-Sumons income ideal. Ser supru note 5

242. See generally William Vickrey. Tax Simpluficalon Through Cumulature Averuging. 3t LAW 
point the practicalities simply call for a relatively flat-rate schedule. This position is, in fact, precisely the conclusion that Mill and Rawls reached. ${ }^{243}$

This flat-rate, prepayment consumption tax model, however, might be in direct conflict with our better-considered objective, political normative judgments. There is nothing magic or sacred about a pure consumption tax; what is important are the underlying norms. There is no a priori reason why these norms would cut in the same direction, across all types or quanta of savings, for example. Indeed, it would be surprising if theoretical ideals translated perfectly into policies consistent with simple labels. We might, contrary to the above model, develop a consumption tax system featuring progressive rates, possibly even quite steeply progressive rates, and levy the tax on the "cash flow," or qualified account, model-that is, as money was spent. ${ }^{244}$ This plan would place the tax burden squarely at the time and place of private consumption, which is precisely what society may want to do on objective moral grounds.

Similarly, there is no conclusive a priori reason to tax all sources or uses of wealth under the same rate schedule. ${ }^{245}$ As suggested above, we could modify the progressive consumption-without-estate tax plan by having separate rate schedules on earned income and inherited wealth. The earned income schedule might feature lower rates to be solicitous to labor-leisure trade-offs, and to isolate out the burden of higher rates for consumption out of capital, or noncurrent period earnings. The schedule on inherited wealth would feature steeper rates to discourage consumption out of this source and to serve liberal egalitarian goals of equality of opportunity. ${ }^{246}$ Of course, we would need practical details such as tracing rules. I envision a simple scheme: Consumption is deemed to come out of current period earnings, savings attributable to prior period earnings, and inheritance, in that order. But I mean to leave precise details to another day. A basic idea is that a separate and higher rate schedule on spending out of inherited capital will actually move the proposal toward the logic of an accessions tax, i.e., one that taxes donees, not donors. In this sense, we can think of the proposal as a type of consumptionmodel accessions tax. Unlike an accessions tax, however, the tax is not levied

\& CONTEMP. PROBS. 736 (1969) (discussing plan for systematic income averaging).

243. As noted above, Rawls qualifies his advocacy by noting that things might come out differently under nonideal theory. THEORY OF JUSTICE, supra note 19, at 279. Hobbes essentially supported a proportionate consumption tax, with some equivocation about how to treat people who controlled the labor of others. See C.B. Macpherson, Introduction to ThOMAS HobBes, LEviATHAN 9, 59-60 (C.B. Macpherson ed., Penguin Books 1968) (1651).

244. See BLUEPRINTS, supra note 238, at 122-25; KALDOR, supra note 189, at 49-53; Andrews, Consumption-Type, supra note 61, at 1120-21, 1126; McCaffery, Hybrid, supra note 5, at 1151.

245. Cf. Deborah M. Weiss, Can Capital Tax Policy Be Fair? Stimulating Savings Through Differentiated Tax Rates, 78 CORNELL L. REV. 206, 208, 217-29 (1993) (discussing role that differentiated rates on capital might play).

246. In this regard, the proposal sounds like the "Rignano" plan. See McNulty, supra note 28, at 87-89. 
on the act or at the time of transfer; instead, the tax is postponed, deliberately, until the time of ultimate consumption, consistent with an ethical focus on use.

Another way to understand or justify this latter aspect of my proposal is to see that it carries down the possession-use distinction to a later generation. Liberalism is more concerned with use than with the mere possession of wealth; its concerns with possession may be largely about possession quat actual or potential use, although there also may be a greater concern about a later generation's inheriting wealth. The concern with the later generation's use, however, may be greater than the concern with that generation's mere possession, especially since the "possession" of wealth is an essentially legal concept whose very meaning, and hence dangers, can change with the regime in place. Thus, we place a higher rate schedule on spending out of inheritance. But the inheritance itself - that is, the actual transfer of wealth-may in fact be the proper response to our objective concerns a generation earlier. We may actively want Mr. Perot (assuming again that income is fairly earned) to work and save, because we value whatever he does to produce that wealth and we appreciate his accumulation of capital, but we nevertheless may be afraid of his spending his billions personally and quickly. If we are concerned about curtailing his extravagant consumption, however, then we have to let him pass on the wealth. We cannot concede Mr. Perot his earnings while at the same time checking both his consumption and his savings: Something has to give. Under the progressive consumption-without-estate tax with a higher rate schedule on spending out of inheritance, we do not burden Mr. Perot's earnings or savings or wealth transfers per se. Instead, we monitor the use of the wealth, both at Mr. Perot's and later generation's levels, to make sure that such use is not decadent or offensive, without pushing Mr. Perot to consume it himself. This approach may be the best real-world balancing of competing values that we can achieve; it is also a thoroughly political liberal answer.

The effects of this progressive consumption-without-estate tax model should be the exact opposite of the current incentives for large inter vivos gifts and conspicuous consumption that the flawed income-plus-estate tax model generates. The proposal thus comports with liberal society's objective, political admiration of work and savings and its suspicion of extravagant personal use. This analysis shows, in the process, that wealth transfer taxation need not be an indispensable ally of equity.

\section{Rational Saving Under a Progressive Consumption Tax}

A few questions remain. For example, one might ask why any rational person would save in the first place, or not consume, knowing that a progressive consumption tax would constrain any future consumption by herself or her heirs. That is, why is not the chilling effect on capital accumulation or work effort equally strong under the progressive consumption- 
without-estate tax (especially with a higher rate schedule on spending out of inheritance) as it is under the more commonly recommended consumptionplus-estate tax, or even under the income-plus-estate tax system? There are at least five possible answers to this question, all of which help to illustrate the appeal of the progressive consumption-without-estate tax proposal.

First, the rate structure would encourage dispersion among bequests, as donors saw the lower rates that were available to a wider range of donees. This aspect of the system would thus serve independent normative purposes: It would serve one of the goals of an accessions tax without all of its problems. As mentioned above, a separate and steeper rate schedule on consumption out of transferred wealth can be seen as a consumption-tax variant of an accessions tax. Second, and related, there is much evidence to support a general tendency for earnings to revert to the mean, inter-generationally. For whatever reason-and there are several possible reasons-exceptionally productive parents are not likely to have high-earning children. ${ }^{247}$ The rational saver might thus expect her child to be in a lower consumption tax bracket than she is in herself.

Third, the revised law could have provisions for the deductibility of certain expenses, such as medical and educational expenses, for oneself or for another. The rational donor (saver) would rest assured that these uses, which she might favor in any event, would both be more likely and less taxed. The law could thus create a sort of spendthrift trust, discouraging only wanton consumption among transferees. Indeed, this structure might even make inter-generational transmissions more attractive, by facilitating thrift among descendants of the thrifty. (The very existence and legal sanctioning of spendthrift trusts lend interpretive support to the proposal.) Differentiation among the uses of wealth is of course fully consistent with the political, objective, ethical focus that I have argued society can and should embrace in considering matters of taxation; certain uses are simply viewed as more urgent than others. ${ }^{248}$ Of course, it is not obvious that unlimited exclusions for medical or educational uses are consistent with the best reading of liberalism; where and how to draw the requisite lines will once again be a matter for sound and reasonable political judgment.

Fourth, there might be "fiscal illusions," or benefits to a putative donor from being able to bequeath a large amount of money in nominal terms, that counterbalance the discounting of the ultimate consumption flow suggested by the tax system. This effect may not be wholly rational, but it fits with a mass of evidence from cognitive decision theory that people value wealth that they

247. See generally Solon, supra note 140 (discussing evidence of mean reversion); Zimmerman, supra note 140 (same). There are at least three possible explanations of varying normative statuses: (1) able parents may have less able children for normal statistical reasons; (2) wealth corrupts carnings abilities; and (3) wealth enables a non-materialist flourishing to transpire.

248. See Scanlon, supra note 14. 
think they own more highly than wealth that they think they do not own. ${ }^{249}$ Cognitive theorists have also found that people are less willing to spend money out of what they think of as capital than out of earnings or cash flow. ${ }^{250}$ Fifth, a rational potential donor may even expect that tax rates might someday go down, as they might indeed if the law attained some of its goals, such as a greater capital stock. The donor thus anticipates a lower tax burden in the future. Saving under such expectations makes sense.

In addition, it is worth noting that individuals who save for life-cycle reasons, or simply out of some entrepreneurial, dynasty-building urge. need not be deterred by the progressive consumption-without-estate tax, although such parties are not necessarily deterred by the presence of an estate tax, cither. The progressive consumption-without-estate tax will not encourage early inter vivos gifts, at least above and beyond what present consumption needs might suggest, or other complex manipulations to avoid its sting. Unproductive planning costs should thus fall. The incentive structure might also increase savings because the most committed savers could hold onto their wealth longer, and younger generations would not have the receipt of early wealth to skew their own incentives to work and save.

To be sure, the progressive consumption-without-estate tax will generate disincentives. Any real-world tax will. But the progressive consumptionwithout-estate tax will only deter those individuals who are working or saving primarily so that they can one day engage in rapid, large-scale consumption. Liberalism, however, has to put its foot down somewhere, and this place seems more reasonable than one that burdens all savers, and lets big spenders off the hook. Rawls and other liberals evince a consistent fear of the large-scale distortionary use of wealth; this is what leads to exercises of power detrimental to prior liberties. A progressive consumption-without-estate tax punishes only those individuals or families who insist on doing just that. If Mr. Perot had been planning to run for President all along, the tax would have hit him hard. But such tough taxation might be exactly the correct liberal result. The progressive consumption-without-estate tax clamps down only on the "selfindulgent aristocracy" while enabling a "frugal capitalist class" to flourish, again using Rawls' language. The tax precisely reverses the effects of the current law by punishing Mr. Spendthrift and not Ms. Thrifty.

Of course, there are some lingering questions. Under the progressive consumption-without-estate tax, nominal wealth would rise, and this greater wealth would probably change elasticities (such as the elasticity of bequests to wealth). The rate structure might be complex, and its precise contours undoubtedly would be difficult to work out; society would have to decide at

249. See Elizabeth Hoffman \& Matthew L. Spitzer. Willingness To Pay vs Willingness To Accept Legal and Economic Implications, 71 WASH. U. L.Q. 59 (1993).

250. See, e.g., RICHARD H. THALER, Mental Accounting and Consumer Chotce, in QLASI RATIONAL ECONOMICS 25, 27 (1991). 
what point and to what degree consumption becomes excessive. ${ }^{251}$ Setting different schedules for earned and inherited wealth would also be difficult, as would carving out medical expense and other deductions or modifications. Transitional concerns cannot be avoided. ${ }^{252}$ These details, however, do not challenge the basic point of these speculations: An awareness of the incentive structure generated by current law, and even by the consumption-plus-estate tax ideal, indicates that we might have our policy recommendations exactly backwards relative to our better-informed normative judgments. We should be looking at the use, and not the mere possession, of resources.

\section{Charitable Contributions}

Finally, a particular concern with the progressive consumption-withoutestate tax may be that it undermines an important incentive to give to charity. Charitable contributions do indeed stand on a different normative footing than the inter vivos incentives discussed above. Charitable deductions under the estate tax are also large: $\$ 6.2$ billion in 1991 , compared to the $\$ 9.1$ billion yield of the estate tax itself. ${ }^{253}$ Although the reform proposal will undeniably remove the tax incentive to give to charity upon death, two responses to the potential problem are in order.

First, there are reasons to be skeptical about the magnitude of the shortfall. Under present tax laws, one needs a genuinely charitable motivation to give to charity, putting aside questions as to whether there are nontax instrumental advantages, such as publicity, from such gifts. Under a 55\% estate tax, a person giving $\$ 10,000$ to charity forgoes the right to make a $\$ 4500$ bequest. The fact of this sacrifice indicates that tax incentives alone do not lead to the charitable contribution, even on death. Indeed, in 1989, only 19\% of decedents in taxable estates made any charitable bequests at all, although the amounts given were substantial. ${ }^{254}$ Nonetheless, evidence has indicated that contributions by the wealthy are somewhat sensitive to both income and estate tax rates, ${ }^{255}$ and there are rational reasons why a potential donor might be somewhat, though not completely, philanthropic. ${ }^{256}$ Moreover, there are

251. This problem, which might seem severe, is actually not conceptually different from deciding when levels of income should be subject to higher rates, and what the rates should be, under a traditional income tax.

252. See generally Michael J. Graetz, Implementing a Progressive Consumption Tax, 92 HARV. L. REv. 1575 (1979) (concluding that practical implementation difficulties militate against adopting consumption-based tax). Among other effects, there might be a large, one-time wealth transfer to those who had been anticipating an estate tax. Mitigating this effect is the fact that many parties facing such a tax have taken steps to avoid it, and that the progressive consumption-without-estate tax, especially with a higher rate schedule on inherited wealth, would continue to tax much of this wealth.

253. Johnson, supra note 56 , at 90-91.

254. Id. at 78.

255. See, e.g., Michael J. Boskin, Estate Taxation and Charitable Bequests, 5 J. PUB. ECON. 27,29 (1976) (discussing data suggesting that charitable bequests are highly sensitive to estate tax rate); see also Bernheim, supra note 2, at 121-32.

256. Two basic ideas come to mind. One is that the donor may value her heir's consumption at 
circumstances where even non-charitably-inclined taxpayers can benefit from the use of certain split-interest transfers. ${ }^{2 s^{-}}$On the other hand. the generally higher tax rates and capital accumulation levels made possible by the progressive consumption-without-estate tax, combined perhaps with the fiscal illusions generated by the cash flow method, may lead to earlier and higher life-cycle charitable gifts. These questions are empirical ones that need to be studied.

Second, and more fundamental, there is no a priori reason why the tax laws must be limited to an exclusion vel non for charitable giving. We could imagine, for example, a negative tax rate: that is, a bonus for contributions above a certain threshold. If charitable contributions are a good-I leave this complex question aside ${ }^{258}$ - there is no reason why we cannot develop an incentive structure for encouraging them within any general system of tax. ${ }^{250}$ It matters not whether charitable contributions fit within neat analytic

more than a charity's, but at some quantum the reduction in $u$ calth that can be transterred to the hetr makes the charitable contribution more attractive. A donor might, for example. prefer leshing $\$ 75$ to her heir than $\$ 100$ to a charity, under a $25 \%$ transfer tax rate. But at a $50 \%$ transfer tax rate. the sarne donor might prefer to give the $\$ 100$ to the charity than to guse $\$ 50$ to the hetr (y supru note $7 t$ and accompanying text. Second, and related, there might be what Sen his called the "isolation" paradox $A$ potential donor needs the assurance of other contributions that the deductibility of the payment in part provides. Under a $50 \%$ tax rate. the government is essentually "matching" the pris ate donor's gift Ste Sen, supra note 83 , at 487-88.

257. See SCHOLES \& WOLFSON. supra note 55. at 577-83 The IRS does not mantun statustics indicating the form of charitable deduction tahen, so there is no way to aseertan the pres alence of split interest gifts that may have strategic, nonchartable mouves

258. See, e.g., William D. Andrews, Personal Deductuons in an ldeal Inemer Fax, 86 Haks L. REV. 309, 344-75 (1972) (supporting chantable contribution deduction), Mark P Gergen. The (asc for a Charitable Contributions Deduction. 74 VA. L. RE 1393 (1988) (discussing arguments). Kelmun. supra note 224, at 835-58 (questioning the deduction). Mciulty. supra note 1 G0 (discusstng urguments)

259. I also leave open the complex questions of whecher a repeal of the gift and estate tax would in fact be supplemented with some countervaling proviston fivoning charitses. and, il not, whether the status quo might be preferable. $1 \mathrm{am}$. howeser. somewhat sheptucal of the al lesst atmpltell ideat that we need to favor public charities by retanning the guft and estate tax Aidug charntie seems like a mall benefit for the potentially large costs of gift and estate taxation In any event. the questuon arises as to why solicitude for charities and the public chanty lobby could be strong enough to help hecp the gilt and estate tax in place, but not to help generate a replacement for is chantable contribution deduction it we were to repeal the estate tax.

This discussion relates to the interesting question of why we do, in fact. hase a gill and estate tax, if (as I am arguing) all of its traditional justifications fal One sec of reasons indy indeed be politu.al. economic: Actors who benefit from the existence of the tax agitale for its retention Large publitc tharities and the specialized gift and estate tax bar and other tinancial professionals come to intund Mlore attenuated, but still possible, is the thought that Congress itself lihes the tax. since periodic threats to raise its rates create favorable rent-seeking opportuntues. Se'e generall, Docrnberg \& NleChesney, supra note 133 (discussing rent-seeking model of tax legislatson)

I am inclined to think that all of these factors play some role. and I atn grateful to Mlichael Wachice for stimulating my thinking on these scores. But I belicie that much of the puzeling perssitence of wealth transfer taxation is due to inertia, to the seemngly untow ard symbolism of repealing the tax. and to the failure to think systematically through both the problems with the present tax regume und the pousbiluties for a better liberal taxing plan. I do not thinh that en! is a ven good explanation for the persstence of the estate tax in practice, nor is 1 necessarily a good explanation in theory. for the sumple reason that the estate tax is not, in fact, popular. See THEORY of J STICt. supra note 19. Al $530-1$ l (dixiussing problems of envy and of envy and equaluty): Young. supra note 178 (same). supra notes 162-70 and accompanying text. 
definitions of "income" or "consumption." What matters is the extent to which such contributions are attractive, and the efficacy of various means to induce them. Freed from debates over prior definitions, we can do much to improve the law. Questions of tax are political all the way down.

\section{The Case Against DoIng Nothing}

The above analysis has had two primary aims: first, to point out the rather severe problems with wealth transfer taxation, in theory and certainly in practice; second, to use a detailed consideration of wealth transfer taxation as a springboard to consider comprehensive tax reform along political liberal lines. On a much broader plane, the analysis has suggested the need to think through some basic questions about the dictates and practices of liberal theory in our real, imperfect world, especially, if not exclusively, vis-à-vis tax. At the end of the day, though, one of the greatest temptations, as always, will be to do nothing at all. This Part addresses two particular arguments for leaving the status quo in place: one, that the estate tax is a harmless "voluntary" tax, or even a positive symbol of liberal egalitarian values; two, that the case for change turns on empirical support that we do not yet have.

\section{A. What's Wrong with a Voluntary Tax?}

One argument for doing nothing at all is that the current estate tax, with all of its flaws, is in fact a sensible balance of competing goals. This argument is of a type that a thoroughgoing interpretivism, which takes our actual practices seriously, might be thought to generate. It is a social, evolutionary argument against any kind of conscious change. It is indeed a rather curious paradox that, given the many escape valves that have effectively made the actual, imperfect estate tax a "voluntary" one, the regime might have backed its way into being an efficient tax, at least in terms of the capital stock. Those parties who care about making bequests find ways to do so, so that the only parties paying the estate tax are those who are inelastic-that is, those who amass capital with complete indifference about whether to pass it on intergenerationally. ${ }^{260}$ If this story were true, then the tax might not have adverse effects on productive work effort or capital formation, or on unproductive consumption. The current, apparently flawed estate tax may in fact be a good system.

I do not accept this story, for several reasons. First, even those parties who have stressed the avoidability of the estate tax have noted its binding effect on

260. COOPER, supra note 2, at 4-7; Kirchheimer, supra note 3, at 1233 (“.'|The estate tax] tends to be a tax, to some extent, on the unwary and the ill-advised, but that's not necessarily a bad thing."') (quoting Canadian economist Richard Bird). 
the very rich. ${ }^{261}$ This class is small but highly important, at least as far as aggregate capital stock goes. ${ }^{262}$ It is too simplistic to say that the estate tax has no disincentive effects on those who pay it. The "voluntary" label or the low overall revenue yield of the estate tax often lulls commentators into maintaining that the likely incentive effects are apt to be small. ${ }^{203}$ This conclusion, however, confuses average with marginal effects. To the ultra-rich facing the estate tax, the disincentives at the margin are hardly trivial, as the numbers in Table 1 suggested, and as I have argued throughout this Article. ${ }^{264}$

Second, there are costs from the means by which bequest-motivated taxpayers avoid the tax. Voluntary taxes are not always efficient. All realworld taxes, including the income tax itself, are in some sense voluntary: In the case of the income tax, taxability depends on the volitional act of earning income. In the case of wealth transfer taxation, the induced behavior may have adverse effects on the capital stock. These effects, however, are not the only or even the most important ones. If capital is diminishing because of increased consumption, increased inter vivos giving, and decreased work effort, then we ought to consider these effects on political liberal grounds as well. Effects may also derive from the incentives at the younger generation's level. Getting wealth early in life may deter heirs from working and saving. ${ }^{20 s}$ The gift and estate tax regime may encourage both early gifts and diminished work and savings. As it now stands, taxpayers can both pass on wealth and avoid taxes; the former is in fact a means to the latter.

Third, taxing the presumably inelastic savers who in fact pay estate taxes is not necessarily efficient, even relative to the question of the aggregate

261. COOPER, supra note 2, at 79-82.

262. See, e.g., Aaron \& Munnell, supra note 6. at 126-32 (discussing data on wealth concentration) Recall Keynes' emphasis on the imponance to England's historical development of the evistence of a small class of highly efficient, aristocratic savers. KEYNES. supra note 228, at 19 ("The immense accumulations of fixed capital which, to the great benefit of manhind. were built up durng the half century before the war, could never have come about in a Socicly where wealth was divided equitably")

263. See, e.g., Graetz, supra note 2, at 279 ("The estate tix is such a small resenue source that its effects on savings and investment are no doubt dwarfed by the impact of other taxes and by fixcal and monetary policies."); Robinson, supra note 2, at 38 ("More than minely-nune percent of the country', estates will escape weath transfer taxation entirely [Such] tixes will therefore likely have only a limited effect on the macro- or micro- management of the nation"s capital wealth"). id at if ("If the wealth transfer taxes only touch one percent of the estates in the country we should simply forget the wealth transfer taxes and concentrate on the more important problems facing the country "). see also Ascher, supra note 2, at 106.

264. Mr. and Mrs. Perot, for example. are facing an estate tax of approximately $\$ 1$ 65 billion See supra note 59 . Every $1 \%$ rise in the estate tax rate costs the Perot family $\$ 30$ million There is no reason to adjust any of these numbers for the uncertainty of death. because their present values hold regardless of the date of death.

265. This effect is somewhat mitigated if, as is usually the case, the form of the inter was transfer restricts the beneficiary's present use of the wealth-as with the popular Crammes trusts, for example Even here, however, the placement of the wealth in trust remoses an important element of uncernanty regarding the ultimate recejpt of the funds. See DoLGLAS HOLTZ-EAKIN ET Al. , supra note $1+1$. at $18-19$ (concluding from empirical evidence that work effort falls after receipt of substantual inhentance), see also discussion of related issues supra par V.C. 
capital stock alone. The capital stock effect is also a function of the government's and inheritors' relative propensities to consume. Assuming arguendo that we are concerned with aggregate savings, we have to ask if savings would increase from allowing even taxpayers who are more or less indifferent to leaving bequests to pass on wealth to their designated heirs, as opposed to ceding much of it to the government. More data is needed, but the Stiglitz-Smith conjecture about relative propensities to consume points to an affirmative answer to this latter question.

A fourth and final problem with the notion that the voluntary tax can in fact be a pragmatic ideal may be the most important concern, at least within a political liberal framework. A voluntary estate tax is a limited tool for furthering equal opportunity and redistribution, both in theory and in practice. The estate tax's very low revenue yield and the continuing inequality of the distribution of wealth suggest that the estate tax is doing little, if anything, to level playing fields. ${ }^{266} \mathrm{~A}$ voluntary estate tax means that wealthy individuals who are unconcerned with, or even opposed to, bestowing large material advantages on their heirs will pay the tax, but all others will find ways to pass on sizable inheritances or to consume wealth themselves. Is this a better world? It is not difficult to mount a strong normative argument that a world with fewer but still many well-endowed heirs, many of them quite young; less aggregate production and capital; and more large-scale consumption by the very rich is not an improvement. The relative advantage of those whose benefactors have opted out of the tax regime is greater, and the lesser capital and distortionary spending of the rich hurt all persons, perhaps especially the working classes. Further, it is not clear that those who pay the tax would have given their entire wealth to their heirs, anyway. It is at least possible that the tax represents their choice of charity.

Perhaps the estate tax is mostly symbolic, a nod in the direction of liberal egalitarian ideals. In that case, perhaps its voluntary nature is perfectly acceptable. There may be little reason for symbols to have real effects. The estate tax becomes a "non-problem problem": something too trivial to worry about. ${ }^{267}$ There are difficulties, however, with this thought. Sometimes, symbolic or ineffectual laws represent legitimate, important social responses to deep, intractable problems. ${ }^{268}$ Other times such laws obscure important

266. See Donaldson, supra note 1, at 541 (discussing low revenue yield); G.P. Verbit, Do Estate and Gift Taxes Affect Wealth Distribution?, 117 TR. \& EST. 598, 602-07 (1978); see also Wolff, supra note 6 (discussing empirical findings on wealth inequality).

267. See, e.g., Robinson, supra note 2 , at 28 (suggesting that wealth transfer "taxes are simply not worth worrying about in light of other pressing national needs").

268. This idea is a general theme in GuIDO CALABRESI \& PHILIP BOBBITT, Tragic Choices (1978); see also ROBERT STANLEY, DIMENSIONS OF LAW IN THE SERVICE OF ORDER: ORIGINS OF THE FEDERAL. INCOME TAX. 1861-1913 (1993) (arguing that progressivity of earlier income tax was largely illusory and was intended to prevent more fundamental change); Marjorie E. Kornhauser, The Morality of Money: American Attitudes Toward Wealth and the U.S. Income Tax, 28 IND. L. REV. (forthcoming 1994) (discussing, inter alia, rhetorical effects of tax law). 
questions and obstruct meaningful change. Still other times, symbolic laws make things worse by having counterproductive effects. Sorting out these very different cases is a critical task of policy analysis.

The failure of the estate tax to be anything other than an empty symbol may be telling us something important about what we should be doing in its stead. Indeed, the puzzle of ineffective and unpopular wealth transfer taxation demands some answer. One answer is that the people have been duped. A different and far more respectful answer is that the people and our implicit practices are right. Dealt an inefficient and unattractive institutional answer by well-intentioned liberals, our actual practices-showing, in this regard. the same goals as the liberal theorists-have all but gutted the estate tax. It is time for political liberals to listen to what these practices are trying to say.

\section{B. Living with Uncertainty}

A final set of questions to address briefly is what to do in the face of empirical uncertainty, and perhaps even indeterminacy, of many key consequential variables. These questions are not decisively important for my enterprise, which is why I can place this discussion here, at the end of the day. What we plausibly know, coupled with an enriched sense of policy options, is enough to confirm that the present estate tax is not a good idea in our imperfect world, and that alternatives are worth considering. In moving toward stronger conclusions, however, such as a full acceptance of the progressive consumption-without-estate tax ideal, some perspective on empirical uncertainty becomes important. It is possible, for example, that the present estate tax loses revenue, constricts capital accumulation, diminishes work effort, and induces conspicuous or large-scale consumption. If true, such facts should give pause to all but the most obstinate supporter of estate taxation on symbolic grounds.

The problem, as anyone who has attempted to grapple with the literature on these questions knows all too well, is that what is "true" about such questions is difficult and perhaps impossible to ascertain. "We have seen that Rawls, in A Theory of Justice, left the details of tax and other economic institutions in part to "plain hunch." ${ }^{.270}$ By the time he wrote Political Liberalism, Rawls had grown even more tentative about institutional issues turning on "complicated inferences and intuitive judgments that require us to assess complex social and economic information about topics poorly understood."271 Dworkin similarly saw that "any practical program" mediating the sometimes opposing goals of ensuring equal opportunity and

269. See, e.8., Ascher, supra note 2, at 92: Gractz. suprat note 2. at 279-80

270. THEORY OF JUSTICE, supra note 19. at 278.

271. Political LIBeralisM, supra note 8 , at 229 
respecting diverse choices and outcomes "will work imperfectly and will inevitably involve speculation, compromise, and arbitrary lines in the face of ignorance." 272 In the particular case of wealth transfer taxation, many of the important economic variables, such as the relevant elasticities, are difficult to uncover; estimates of labor supply and savings elasticities vary widely. We have seen that there is much dispute over why people save or make gifts, and over the motives for their working and amassing of fortunes. What should realworld policy planners do in the face of this uncertainty?

Beyond dispute, the process of data gathering should continue and indeed accelerate. There is much that we simply do not know about the behavior of the very wealthy that seems unquestionably relevant to the questions before us. The IRS maintains no systematic studies or records on gift tax returns. We have little if any idea of the extent of use of the annual, medical, or educational gift tax exclusions. We do not know very much about the presumably quite wealthy individuals who are using up some or all of their unified credit in making inter vivos gifts. The IRS also maintains no records on the type of charitable gifts qualifying for estate tax deductions, so that we do not know, for example, the extent or incidence of split-interest giving, or how much "charity" may actually be sophisticated tax minimization. Uncertainty about our ability to reach determinate answers is not a good reason for not trying, however, especially since ad hoc assumptions and anecdotal evidence drive so much of the literature on wealth taxation. ${ }^{273}$

But there is still more to say. The typical advocate of the estate tax reasons somewhat along the following lines: The data on contrary effects is inconclusive if not indeterminate, and therefore we should fall back on our best political instincts and intuitions, which favor taxation of the very wealthy in general and of wealth transmissions in particular. Rawls' reliance on "hunch" is perhaps the leading example of this type of reasoning. ${ }^{274}$ Estate tax advocates often begin with the tax as a means to an end, say of revenue raising or equal opportunity or progressivity, and then continue to cling to it even when its relationship to that end has been called into question. The means become an end, and we evaluate facts in light of existing patterns of belief. If popular opinion or our actual practices seem to conflict with the dictates of prior theory, the people must be wrong or deluded. I have tried to suggest that this way of thinking might be dangerously wrong. ${ }^{275}$ A happy invocation of

272. Dworkin, Matter of Principle, supra note 20, at 207.

273. I readily concede that many of the relevant pieces of information will be hard to uncover. See. e.g., Robinson, supra note 2, at 43.

274. THEORY OF JUSTICE, supra note 19, at 278.

275. In this regard, this Article parallels my arguments in McCaffery, Slouching, supra note 194. an article that otherwise reflects a rather different set of concerns and a different normative and methodological approach. There I argued, in part, that focusing on the gender wage gap in salaries might also be a "dangerously wrong measure[] of what truly matters," id. at 598; see also id. at 674, and more narrowly that the equal pay aspects of Title VII might be means masquerading as ends to the detriment 
a priori insights cannot allow us simply to dismiss what evidence we do have, nor can we ignore the possibility of significantly counterproductive results. We should, at the very least, engage in a more careful risk-of-error analysis. Which consequences seem worst, and for what reasons? What are our best-guess odds of various outcomes obtaining? What are the worst-case scenarios that can emerge from any particular reform option?

I believe that we can also go beyond this more sophisticated risk analysis. We do know some things. We know, for example, that wealth inequality remains rather severe, regardless of the presence of a nominally steep gift and estate tax. We know that the estate tax raises little revenue, in absolute or relative terms, with or without adjusting for administrative costs and possible income tax losses. We know that individuals are making large inter vivos gifts, and that they are taking many other steps to avoid the sting of the tax. We know that the tax features high marginal rates, against which general economic theory cautions. ${ }^{276}$ We know that large public and private resource costs are involved in implementation and enforcement of the estate tax. We know that there is general concern about the level of American capital accumulation, and that the capital stock has important intra-generational effects. And we know that wealth transfer taxation is not popular, even though it applies only to a tiny segment of society.

These known facts ought to cast some doubt on the received wisdom and heighten the call for alternative approaches. The case for a change of approach is all the more compelling when we can reason our way toward alternative means for furthering liberal goals and achieving some of the aims that matter to wealth taxation advocates, such as greater equality of opportunity and the improved welfare of the lower classes. Questioning the estate tax does not require that we fall into naive libertarianism or the comforting arms of trickledown theory. We can design a tax system that constrains the private use of wealth without creating all of the perverse incentives and resource costs of the status quo. This is the point of the progressive consumption-without-estate tax. Is not this-or something-worth a try?

\footnotetext{
of more creative and structural reform. Id. at 655-56. Both anteles reflect my quest for a neher political and moral theoretical basis for tax policy analysis. Here. I consider the more or less internal (to tax) logic of wealth transfer taxation, income versus consumption. and progressivity There I looked at the interface between taxes and gender discrimination. It seems to me that a complete liberal theory of tax must do both things: look at the internal logic of tax and consider various interactive effects on a uide range of matters. In both cases we ought to be political: creative, imaginatuve, and free of metaphysical constraints in our search for alternatives, respectful of the often implicit and inchoale spirit of our actual practices. and always on guard against the seductive skeptucism that would have us do nothing at all The broader project of bringing liberal political theory to tax, present in both anicles. is enomously challenging but. I believe, both necessary and promising.

276. See McCaffery, Slouching, supra note 194, at 658 n.216 and sources cited therein. Slemrod, supra note 133 , at $166-68$.
} 


\section{CONClusion}

This Article began with a puzzle: Liberal egalitarian political theory has long advocated some form of wealth transfer taxation, but our settled practices and popular opinion in contemporary democratic societies are strongly opposed to any effective gift and estate tax. Working it through, we came to the curiously surprising conclusion that the people and our practices may just be right, on strictly liberal grounds. The estate tax penalizes the productive work and savings efforts of our wealthiest citizens, while doing nothing about, indeed even inducing, their large-scale consumption of resources. In contrast, a progressive consumption-without-estate tax, with certain sensible modifications, consistently implements the logic of a political concern over the private use of resources. Liberal society reasonably likes work and savings, but only or at least especially reasonably dislikes large-scale private consumption. This position emerges both interpretively, from a sympathetic reading of our practices, and normatively, from an objective ethical approach to the urgency of wants.

In conclusion, I want to generalize the story a bit, to move to an even larger plane. Here is a bigger puzzle: At the very time that our leading liberal political philosophers are telling us that it's all politics, our practical liberal politics are in disarray and retreat. Republicans and centrist Democrats have occupied the White House for nearly three decades, and an antigovernment, antitaxation fervor has been shaping state and national politics, with no apparent end in sight. This history is a bit odd, for a commonsensical view would predict that a reasonable liberal politics, say in a Rawlsian vein, would be redistributive-that, even if we did not take matters all the way to the radical redistributive point inherent in Rawls' difference principle, modern democracies would at least tend toward exacting a greater sacrifice from the wealthy. Yet our actual tax systems are at best only weakly progressive, and at worst not progressive at all. ${ }^{277}$ This Article suggests one rather large part of an answer to the puzzle. Practical liberal politics have gotten our objective social values wrong, have dwelled on poor institutional means for advancing the liberal program, have put the people to hard choices between progressivity and productivity, and have, most and worst of all, failed to listen. The people are not illiberal; their liberal leaders have failed them.

The estate tax illustrates the problem. While a priori liberal theory supports the tax, and it was hardly negligent to implement it in 1916, the people's opposition and seventy-five years of increasingly settled practices have shown that democratic society does not want any meaningful wealth

277. I detail some of this movement-e.g., the trend towards reliance on payroll, sales and usc, and corporate income taxes, and not on personal income ones-in McCaffery, Cognitive Theory, supra note 10. That article also presents what I take to be another part of the answer to the puzzle: Persistent cognitive error favors broad-based and regressive tax systems. 
transfer tax. Yet it is apparent that the liberal theorists and the people have an alignment of ends on this score. Opposition to effective estate taxation is not a case of the majority of the people acting out of envy or spite, and having to be checked by a noble liberal elite; the people are resisting a tax on the wealthiest minority of citizens. Rather than listening to the inchoate voices of the people and our practices, liberals have continued to insist on some form of wealth transfer tax. even moving recently to up the stakes and implement confiscatory taxes. The call for stronger wealth transfer taxes has come politically, from the likes of George McGovern, and theoretically, from philosophers and legal academics. But we ought to begin by presuming that the people are at least sensible, and entitled to respect, and it indeed turns out that there are good liberal reasons to oppose wealth transfer taxes. As mentioned above, such taxes hit at work and savings and induce consumption, especially the large-scale, distortionary consumption of the very wealthy. In contrast, a progressive consumption-without-estate tax-a system toward which our practices may best be seen as moving-reverses these effects, to punish only excessive use, while changing the very meaning and hence the dangers of private possession. A progressive consumption-without-estate tax makes literal-takes to the hilt. so to speak-the longstanding, objectively grounded metaphor of the common store or pool of social resources.

In the beginning and in the end, tax is politics. It is all politics, politics through and through. No dictionary definitions, no metaphysics of natural rights or entitlements theory, no quasi-science of individual utility functions. can see us through, can dictate the choices we must make. But while it is often thought or said that all reason and logic stop at the point where we reach the conclusion that something is all politics-as if all politics meant just politics, in some trivializing sense-the trend in modern liberal theory points decisively otherwise. If tax is indeed all politics. we have all the more reason both to probe our liberal reasons and to pay careful, respectful attention to our practices. This logic is even, and indeed especially, true where such attention to practices takes us to surprising, counterintuitive places, as in the case of estate taxation. If liberal politicians are to use the power implicit in the emergent program of political liberalism wisely and well, they must try harder to get it right. It is too important not to do so. 
